\title{
Characteristics of Water Quality and Streamflow, Passaic River Basin Above Little Falls, New Jersey
}

GEOLOGICAL SURVEY WATER-SUPPLY PAPER 2026

Prepared in cooperation with the State of New Jersey, Department of Environmental Protection, and the Passaic Valley Water Commission

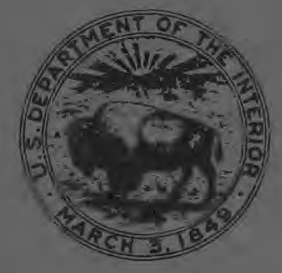




\section{Characteristics of Water Quality and Streamflow, Passaic River Basin Above Little Falls, New Jersey}

By PETER W. ANDERSON and SAMUEL D. FAUST

GEOLOGICAL SURVEY WATER-SUPPLY PAPER 2026

Prepared in cooperation with the State of New Jersey,

Department of Environmental Protection, and the

Passaic Valley Water Commission

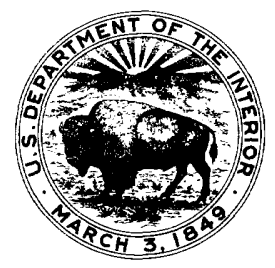




\section{UNITED STATES DEPARTMENT OF THE INTERIOR}

ROGERS C. B. MORTON, Secretary

\section{GEOLOGICAL SURVEY}

V. E. McKelvey, Director

Library of Congress catalog-card No. 72-600304

For sale by the Superintendent of Documents, U.S. Government Printing Office Washington, D.C. 20402 - Price 70 cents domestic postpaid or 45 cents GPO Bookstore Stock Number 2401-02371 


\section{CONTENTS}

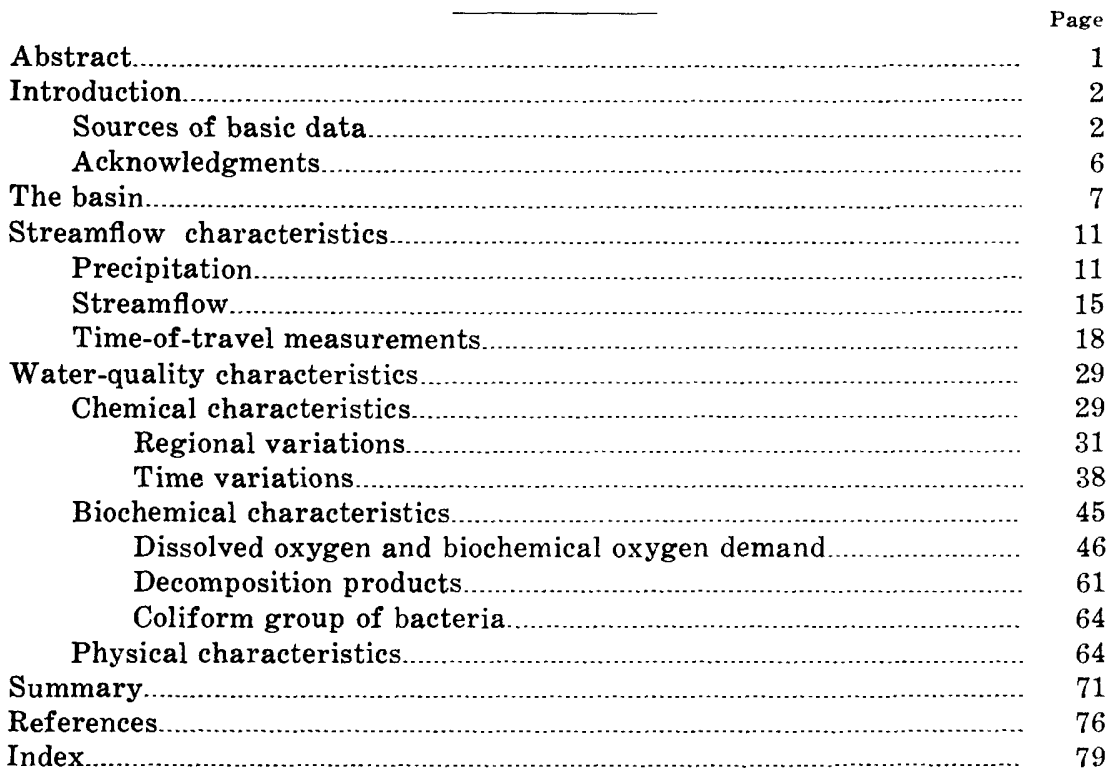

\section{ILLUSTRATIONS}

Figure 1. Map of the Passaic River basin, showing stream-quality sampling sites and streamflow gaging stations.

Page

2. Map showing location of principal water-supply diversions and waste-water discharges during 1970.

3-33. Graphs showing:

3. Normal seasonal variations in precipitation and air temperature in the northern climatologic division of New Jersey.....

4. Cumulative departure from normal of monthly precipitation for New Jersey's northern climatologic division, 1945-70.

5. Comparison of flow-duration curves developed for four time periods on the Passaic River at Little Falls.

6. Twelve-month moving average of streamflow at selected gaging stations.

7. Leading-edge, peak, and trailing-edge traveltime and streamflow data; Passaic River between Chatham and Little Falls, and Pompton and Passaic Rivers between Pompton Plains and Little Falls 
Figures 3-33. Graphs-Continued

8. Variations in traveltimes of peak dye concentration during different streamflow conditions.

9. Traveltime versus distance downstream from Chatham at selected streamflow rates observed at the Chatham gaging station

10. Dispersion of a dye cloud with both time and distance.

11. Generalized relation between dissolved solids and streamflow at four main-stem sampling sites.......

12. Relation between physiography and the prevalent chemical character and dissolved-solids content at low streamflow in the Passaic River basin......

13. Twelve-month moving average of the concentrations of several chemical-quality parameters, Passaic River at Little Falls

14. Twelve-month moving average of the loads of several chemical-quality parameters, Passaic River at Little Falls.

15. Relation between water discharge and dissolved solids, Passaic River at Little Falls, derived by linear-regression analysis

16. Twelve-month moving average of chloride at selected sampling sites.

17. Twelve-month moving average of $\mathrm{DO}$ and BOD, Passaic River at Little Falls

18. Relation between water discharge and BOD, Passaic River at Little Falls, derived by linearregression analysis..

19. Seasonal relation between water discharge and BOD, Passaic River at Little Falls, derived by linear-regression analysis for the period 1951-70

20. Relation between water discharge and DO, Passaic River at Little Falls, derived by linearregression analysis.

21. Seasonal relation between water discharge and DO, Passaic River at Little Falls, derived by linear-regression analysis for the period 1951-70

22. Relation between water discharge and concentration of "reserve" DO, Passaic River at Little Falls.

23. Seasonal relation between water discharge and concentration of "reserve" DO, Passaic River at Little Falls, 1951-70.

24. Twelve-month moving average of DO at selected sampling sites on the Passaic River

25. Twelve-month moving average of BOD at selected sampling sites on the Passaic River.

26. Projected BOD load in the Passaic River at Little Falls at long-term mean annual streamflow......

27. Projected DO load in the Passaic River at Little Falls at long-term mean annual streamflow 
Figures 3-33. Graphs-Continued

Page

28. Twelve-month moving average of ammonia and nitrate at several sampling sites on the Passaic River.

29. Twelve-month moving averages of coliform-bacteria counts at several sampling sites on the Passaic River.

30. Double-mass curves of air and water temperatures at Little Falls.

31. Relation between sediment discharge and water discharge for three sampling locations.

32. Twelve-month moving averages of stream turbidity at Little Falls.

33. Particle-size distribution of suspended sediment at three sampling sites in the Passaic River basin during high and low storm discharges, 1964-67.

\section{TABLES}

TABLE 1. Chemical analyses of surface waters in the Passaic River basin, 1923-25.

2. Water-quality parameters usually determined by U.S. Geological Survey, New Jersey State Department of Environmental Protection, and Passaic Valley Water Commission.

3. Descriptive material on stream-quality sampling sites and streamflow gaging stations...

4. Summary of precipitation data, 1945-70

5. Tabulation of streamflow-frequency information at selected gaging stations in the Passaic River basin for the period of record, for the standard reference period, 1931-60, and for the study period, 1945-70.

6. Results of time-of-travel measurements, 1963-70.

7. Maximum and minimum observations of water-quality parameters by the U.S. Geological Survey, 1962-70.

8. Maximum and minimum observations of trace elements by the U.S. Geological Survey, 1962-70.

9. Maximum and minimum observations of phosphate, detergent, and phenolic-material content by the U.S. Geological Survey, 1962-70.

10. Observed monthly and annual suspended-sediment discharge in the Passaic River basin, 1963-68.

11. Estimated frequency of suspended-sediment discharges at three sampling sites in the Passaic River basin. 


\title{
CHARACTERISTICS OF WATER QUALITY AND STREAMFLOW, PASSAIC RIVER BASIN ABOVE LITTLE FALLS, NEW JERSEY
}

\author{
By Peter W. Anderson and Samuel D. Faust
}

\section{ABSTRACT}

The findings of a problem-oriented river-system investigation of the waterquality and streamflow characteristics of the Passaic River above Little Falls, N.J. (drainage area $762 \mathrm{sq} \mathrm{mi}$ ) are described. Information on streamflow duration, time-of-travel measurements, and analyses of chemical, biochemical, and physical water quality are summarized. This information is used to define relations between water quality, streamflow, geology, and environmental development in the basin's hydrologic system. The existence, nature, and magnitude of long-term trends in stream quality-as measured by dissolved solids, chloride, dissolved oxygen, biochemical oxygen demand, ammonia, nitrate, and turbidity-and in streamflow toward either improvement or deterioration are appraised at selected sites within the river system.

The quality of streams in the upper Passaic River basin in northeastern New Jersey is shown to be deteriorating with time. For example, biochemical oxygen demand, an indirect measure of organic matter in a stream, is increasing at most stream-quality sampling sites. Similarly, the dissolved-solids content, a measure of inorganic matter, also is increasing. These observations suggest that the Passaic River system is being used more and more as a medium for the disposal of industrial and municipal waste waters.

Dissolved oxygen, an essential ingredient for the natural purification of streams receiving waste discharges, is undersaturated (that is, below theoretical solubility levels) at all sampling sites and is decreasing with time at most sites. This is another indication of the general deterioration of stream quality in the upper basin. It also indicates that the ability of the river system to receive, transport, and assimilate wastes, although exceeded now only for short periods during the summer months, may be exceeded more continually in the future if present trends hold.

Decreasing ratios of ammonia to nitrate in a downstream direction on the main stem Passaic River suggests that nitrification (the biochemical conversion of ammonia to nitrate) as well as microbiological decomposition of organic matter (waste waters) is contributing to the continued and increasing undersaturation of dissolved oxygen in the river system.

Passaic River streams are grouped into five general regions of isochemical quality on the basis of predominant constituents and dissolved-solids content during low flows. The predominant cations in all but one region are calcium and magnesium (exceeding 50 percent of total cations); in that region, where man's activities probably have altered the natural stream waters, the percentage of sodium and potassium equals that of calcium and magnesium. In two of the five regions, the predominant anion is bicarbonate; a combination 
of sulfate, chloride, and nitrate is predominant in the other three regions. Dissolved-solids content during low flows generally ranges from 100 to 600 milligrams per liter.

Several time-of-travel measurements within the basin are reported. These data provide reasonable estimates of the time required for soluble contaminants to pass through particular parts of the river system. For example, the peak concentration of a contaminant injected into the river system at Chatham during extreme low flow would be expected to travel to Little Falls, about 31 miles, in about 13 days; but at medium flow, in about 5 days.

\section{INTRODUCTION}

The State of New Jersey and the U.S. Geological Survey in 1962 began a cooperative program to appraise the quality of the State's surface waters. The initial effort was a reconnaissance survey (Anderson and George, 1966) of the existing knowledge of the State's stream systems in relation to water-quality problems. This survey was used by the cooperating agencies in improving the design of sample collecting and in determining further work on specific problem-oriented river-system studies. The Passaic River basin was selected under the cooperative program to be the initial problem-oriented project area.

Accordingly, the State and the U.S. Geological Survey joined in 1963 with the Passaic Valley Water Commission in a cooperative investigation of the stream-quality and flow characteristics of the Passaic River above Little Falls, N.J. This area was chosen because of the large diversions for water supply at and above Little Falls (drainage area of about $760 \mathrm{sq} \mathrm{mi} \mathrm{(square} \mathrm{miles),} \mathrm{or} \mathrm{about} 80$ percent of the total basin area). Also, long-term stream-quality and flow data are available. Initially, the project was scheduled for completion within 3 years; however, because of an extensive drought, 1961-66, the cooperating agencies extended the project life until relatively normal hydrologic conditions returned.

This project was designed for the purposes of collecting facts to understand better the relations between stream quality, streamflow, precipitation, geology, and environmental development in the basin's hydrologic system; appraising the existence, nature, and magnitude of long-term trends in stream quality and flow; and providing information on traveltimes required for soluble contaminants to pass through parts of the river system.

This report describes the results of the investigation and summarizes the information collected.

\section{SOURCES OF BASIC DATA}

Basic records on the quality of the basin's streams have been collected by several State agencies. Reports of the State Geologist, dating from the mid-1800's, contain chemical analyses of water 
samples collected at several sampling sites in the basin. A systematic, periodic collection and analysis of water samples was begun in the late 1920's by predecessors of the present State Department of Environmental Protection. Generally, these records are unpublished but are available for inspection from the State Division of Water Resources (1928-42, 1958 to date). In addition, some specialized information is available from the State Division of Fish, Game, and Shellfisheries and from various research laboratories at Rutgers-The State University.

Stream-quality records collected by the State are augmented and supplemented by those of potable-water-supply agencies. Long-term records, many extending back to the 1920's, have been collected by the Passaic Valley Water Commission, North Jersey District Water Supply Commission, Newark's Division of Water Supply, Jersey City's Water Department, and others. These records are generally unpublished; however, recent records are available from agency laboratories.

Some basic stream-quality records have been collected by Federal agencies, mainly the Environmental Protection Agency and the U.S. Geological Survey.

The Environmental Protection Agency recently completed a report for the U.S. Army Corps of Engineers to determine and evaluate the need for and the value of storage for municipal and industrial water supply and to assess flow regulation for waterquality control in the basin through the year 2020. This unpublished report contains some chemical analyses and graphical profiles of water-quality parameters. In addition, in a recent conference held by the Environmental Protection Agency concerning pollution problems in the Hudson River and its tributaries, a report on the quality of interstate waters of the lower Passaic River was included (Bromberg, 1969). This report contains information pertaining to the area below Little Falls.

The U.S. Geological Survey has reported its water-quality studies in the basin in three interpretive reports. Leighton (1902) reported on sewage pollution in the metropolitan area near New York City and its effect on inland water resources. However, no water analyses are contained in this report. Collins and Howard (1927) reported on chemical analyses of samples collected during 1923-26 from major streams in New Jersey and discussed the suitability of these streams for different industrial uses. For historic interest and for comparison with more recent records presented later in the text (table 7), analyses of water from basin streams contained in this earlier report (p. 116) are reprinted in 


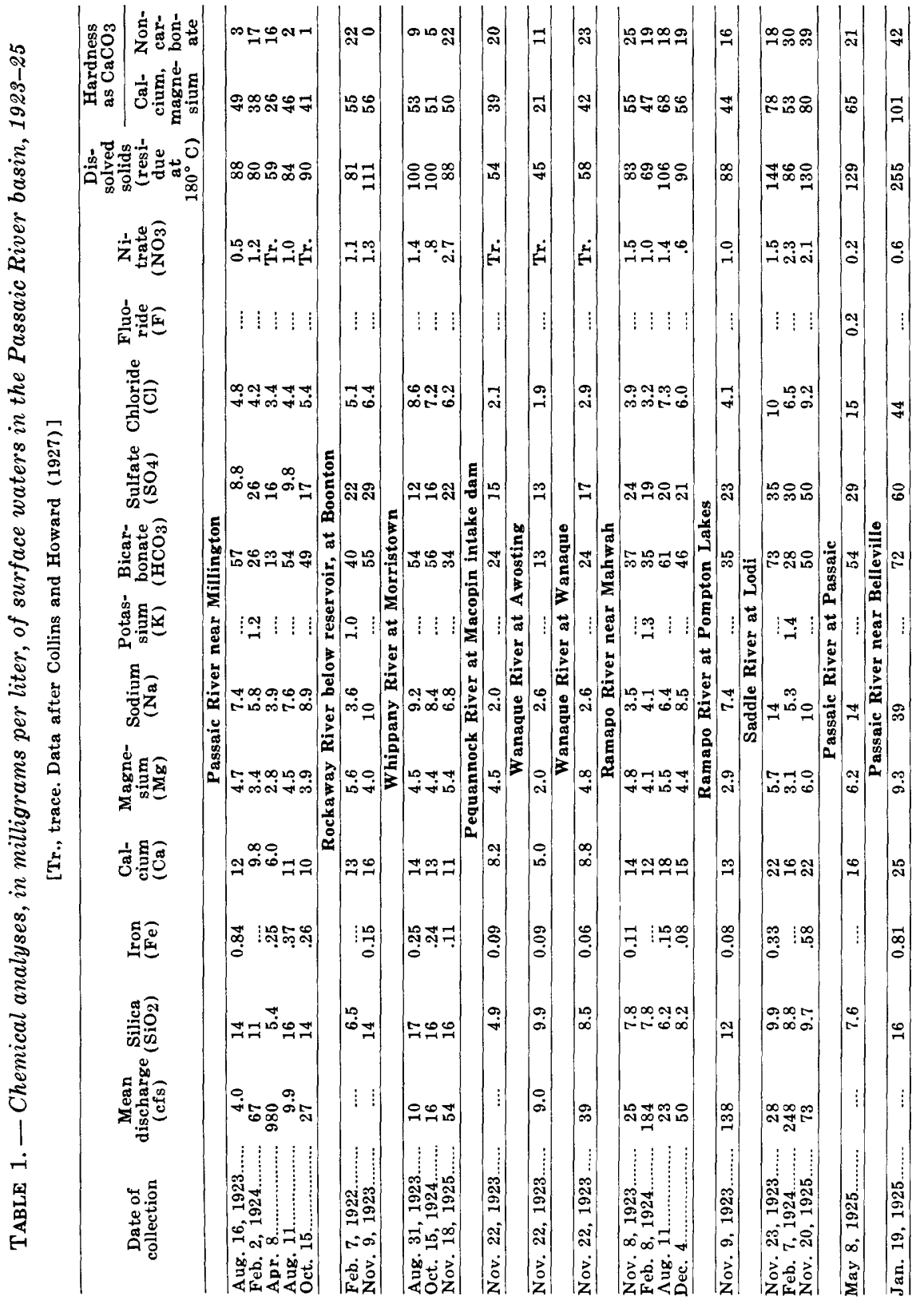


table 1. Anderson and George (1966) reported on a reconnaissance of the State's streams and briefly described the relations between water quality and its environment and the areal and time variations of several water-quality parameters. Although some representative chemical analyses of streams were presented, this report mainly described regional variations in constituent concentrations expected during particular streamflow patterns and was based almost entirely on the unpublished records of the State Division of Water Resources.

In addition to these three interpretive reports, basic waterquality data collected as part of the cooperative program with State and other governmental agencies are published annually by the U.S. Geological Survey in its Water-Supply Paper series titled "Quality of Surface Waters of the United States." Records subsequent to the 1964 water year also are published in annual basicdata releases titled "Water Resources Data for New Jersey, Part 2, Water Quality Records." Distribution of these latter reports is limited, because they are designed primarily for rapid release of data shortly after the end of the water year to meet local needs.

Systematic streamflow data also are collected in the Geological Survey's cooperative program with the State and other governmental agencies at 31 continuous-recording gaging stations, 19 of which are operated currently (1972). Ten of these 19 stations have been in operation for 40 years or more, and only one has been operated for less than 10 years. In addition, data on reservoir elevations are collected at nine sites, and data on water diversion, at six sites. These data are augmented by random streamflow measurements at an additional 48 low-flow partial-record stations.

Basic streamflow records from 1898-1965 were reported in compilation form (U.S. Geological Survey, 1960, p. 151-186; 1964, p. 99-128, and 1970 , p. 332-411). Since 1961, streamflow records have been published by the U.S. Geological Survey in annual basicdata releases ("Water Resources Data for New Jersey, Part 1. Surface Water Records").

In the analysis of water quality of the basin's streams, the authors have drawn primarily on data collected by the Passaic Valley Water Commission since 1945, the State Division of Water Resources since 1958, and the U.S. Geological Survey since 1962. The water-quality parameters usually determined by each agency are given in table 2. Other sources of data are acknowledged in the text. Locations of major stream-quality sampling sites and streamflow gaging stations in the basin are shown in figure 1. Descriptive material on these stations is given in table 3. 
TABLE 2. - Water-quality parameters usually determined by U.S. Geological Survey (USGS), New Jersey State Department of Environmental Protection (NJDEP), and Passaic Valley Water Commission (PVWC)

\begin{tabular}{|c|c|c|}
\hline Water-quality parameter & NJDEP & PVWC \\
\hline $\begin{array}{l}\text { Silica (SiO }) \\
\text { Iron (Fe) } \\
\text { Manganese (Mn) } \\
\text { Calcium (Ca) } \\
\text { Magnesium (Mg) } \\
\text { Sodium ( } \mathrm{Ma}) \\
\text { Potassium (K) }\end{array}$ & $\times$ & 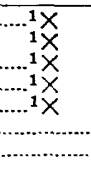 \\
\hline $\begin{array}{l}\text { Bicarbonate (HCO3) } \\
\text { Carbonate (CO3) } \\
\text { Sulfate (SO4) } \\
\text { Chloride (Cl) } \\
\text { Phosphate (PO4) } \\
\text { Fluoride (F) }\end{array}$ & $\stackrel{x}{x}$ & $\stackrel{\substack{x \\
x}}{x}$ \\
\hline $\begin{array}{l}\text { Nitrogen: } \\
\text { Nitrate (NO3) } \\
\text { Nitrite (NO2) } \\
\text { Ammonia (NH3) } \\
\text { Organic }\end{array}$ & $\begin{array}{r}x \\
x \\
x\end{array}$ & $\underset{1}{\stackrel{x}{x}}$ \\
\hline $\begin{array}{l}\text { Dissolved solids } \\
\text { Minor elements } 2\end{array}$ & $x$ & ${ }^{1} \times$ \\
\hline $\begin{array}{l}\text { Hardness (calcium, magnesium) } \\
\text { Radiochemical }(\alpha, \beta, \text { Ra, U) }\end{array}$ & $\begin{array}{l}x \\
x\end{array}$ & $1 \times$ \\
\hline pH & $x$ & $x$ \\
\hline Color & $\dot{x}$ & $\stackrel{x}{x}$ \\
\hline Turbidity &.$x$ & \\
\hline 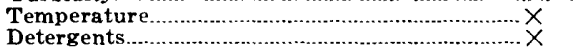 & $\hat{x}$ & $\hat{x}$ \\
\hline $\begin{array}{l}\text { Coliform bacteria (MPN/100 mi) } \\
\text { Total plate count (counts per } 100 \mathrm{ml} \text { ) }\end{array}$ &.$x$ & $\frac{x}{x}$ \\
\hline $\begin{array}{l}\text { Total plate count }(\text { counts per } 100 \mathrm{ml}) \\
\text { Dissolved oxygen }\end{array}$ & $\ldots x$ & $\hat{x}$ \\
\hline $\begin{array}{l}\text { Biochemical oxygen demand } \\
\text { Free carbon dioxide }\end{array}$ & 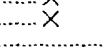 & $\hat{x}$ \\
\hline
\end{tabular}

1Only at Little Falls sampling site.

Includes aluminum, barium, beryllium, boron, chromium, cobalt, copper, lead, lithium, molybdenum, nickel, rubidium, silver, strontium, tin, titanium, vanadium, and zinc.

\section{ACKNOWLEDGMENTS}

The authors are indeed grateful to the following men for their most helpful advice, guidance, and support during this project: Mr. R. J. Sullivan, Commissioner of the State Department of Environmental Protection; Mr. E. R. Segesser, Assistant Director of the State Division of Water Resources; Mr. G. R. Shanklin, former Director of the State Division of Water Policy and Supply ; Mr. L. G. MacNamara, former Director of the State Division of Fish, Game, and Shellfisheries; and Mr. W. R. Inhoffer, General Superintendent and Chief Engineer of the Passaic Valley Water Commission.

Acknowledgment is made also to Messrs. F. J. DeHooge and R. E. Roby of the Passaic Valley Water Commission and Mr. D. M. Clark of the State Division of Water Resources for their valued assistance in providing much of the basic stream-quality data upon which this report is based. The authors are exceedingly grateful also to Mr. A. B. Pyle of the State Division of Fish, Game, and Shellfisheries for the kind loan of equipment necessary for the time-of-travel measurements and to several members of the State 
Division of Water Resources staff who assisted in the collection of samples during these measurements.

\section{THE BASIN}

The Passaic River and its tributaries drain $950 \mathrm{sq} \mathrm{mi}$, of which about $800 \mathrm{sq} \mathrm{mi}$, or roughly 85 percent, is in northeastern New Jersey; the remainder is in southeastern New York State. It is the third largest drainage system in New Jersey, exceeded only by the Delaware River basin, with 2,345 sq mi within the State's boundary, and the Raritan River basin, with 1,105 sq $\mathrm{mi}$.

The river rises in Mendham Township, south-central Morris County, and drains all of Passaic County and parts of Morris, Somerset, Union, Essex, Hudson, and Bergen Counties in New Jersey and parts of Orange and Rockland Counties in New York. Major tributary systems are the Rockaway River system (205 $\mathrm{sq} \mathrm{mi})$, which includes the Whippany River (68.9 $\mathrm{sq} \mathrm{mi})$; the Pompton River system (381 sq $\mathrm{mi}$ ), which includes the Pequannock (88.0 sq mi), Wanaque (111 sq mi), and Ramapo (158 sq mi) Rivers; and the Saddle River system (60.5 sq $\mathrm{mi}$ ). The Passaic River and some of its lower tributaries are tidal in their lower reaches. Head of tide on the main stem is at Dundee Dam in Garfield, about 14 miles above the river's mouth at Newark Bay.

The basin is one of the most urbanized major river basins in New Jersey, and its waters are utilized perhaps more than those of any other basin. Although the river system is used for some recreational and agricultural purposes in the headwater areas, it is used principally as a source of water supply for both public and industrial needs and as a medium for the disposal of municipal and industrial waste waters. There were 10 water-supply purveyors in 1970, who used the basin's streams as a source of potable water (fig. 2), and almost 160 municipal and industrial wastewater treatment plants, which used the streams for disposal of their treated effluents.

Use of the basin's streams has been extremely heavy during recent years, and greater use is indicated for the future. For example, potable-water diversions at and above Little Falls increased more than 8 percent during 1950-60, from about 240 to $260 \mathrm{mgd}$ (million gallons per day), and by 1970 they were about $320 \mathrm{mgd}$, a gain of more than 30 percent since 1950 . Thus, during $1950-70$, the annual rate of increase in potable-water demands was approximately $4.0 \mathrm{mgd}$. Similarly, the reported amount of treated waste-water effluents discharged into the basin's streams above Little Falls increased during 1963-70 from about 33 to 60 mgd, or about 75 percent. Discrepancies between diversions and discharges are due to extrabasin uses and subsequent waste-water 
disposal in Newark Bay. Records of diversion and of waste-water discharges were obtained from the State Division of Water Resources.
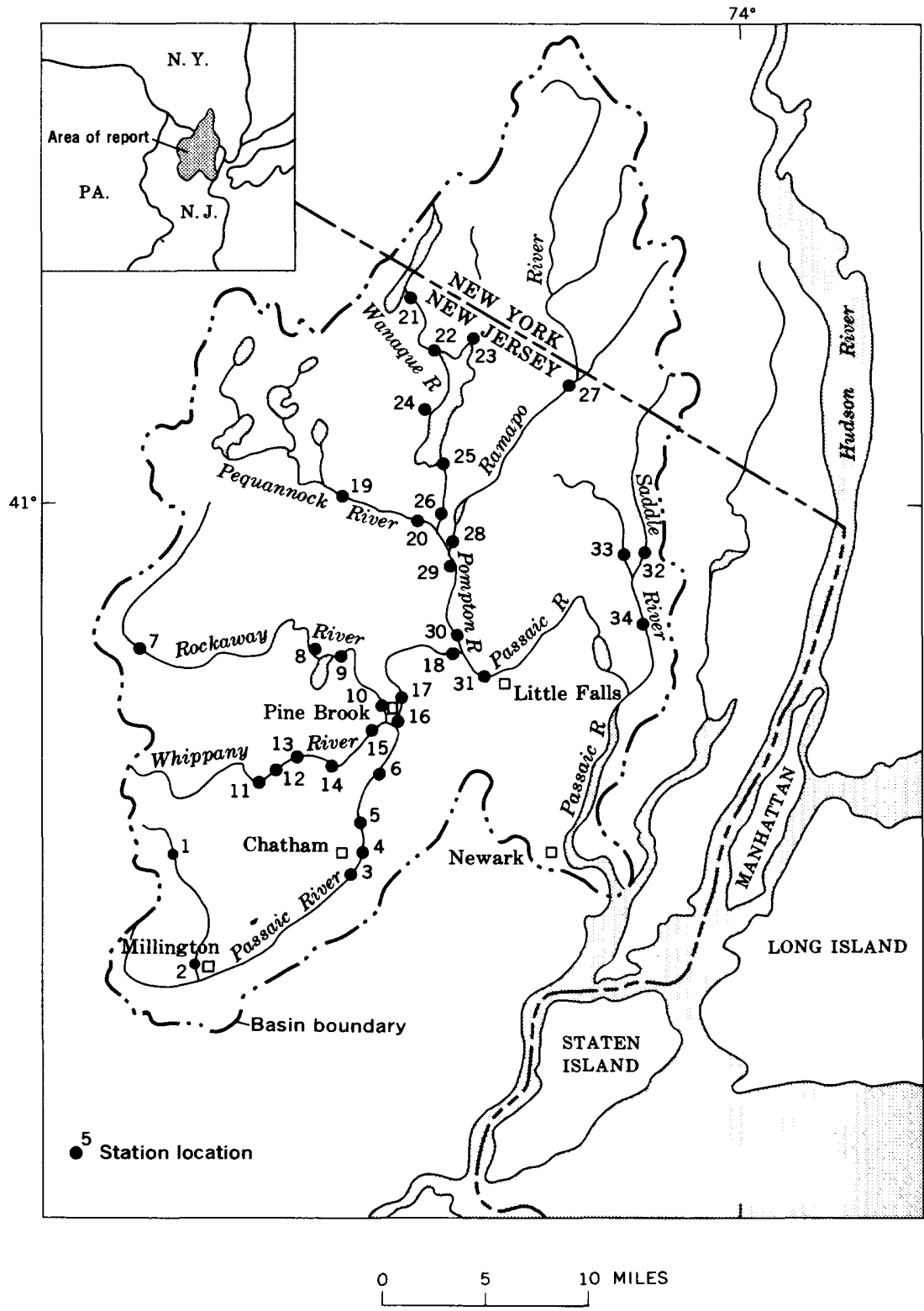

Figure 1. - Passaic River basin, showing stream-quality sampling sites and streamflow gaging stations. Numbers refer to those in table 3. 


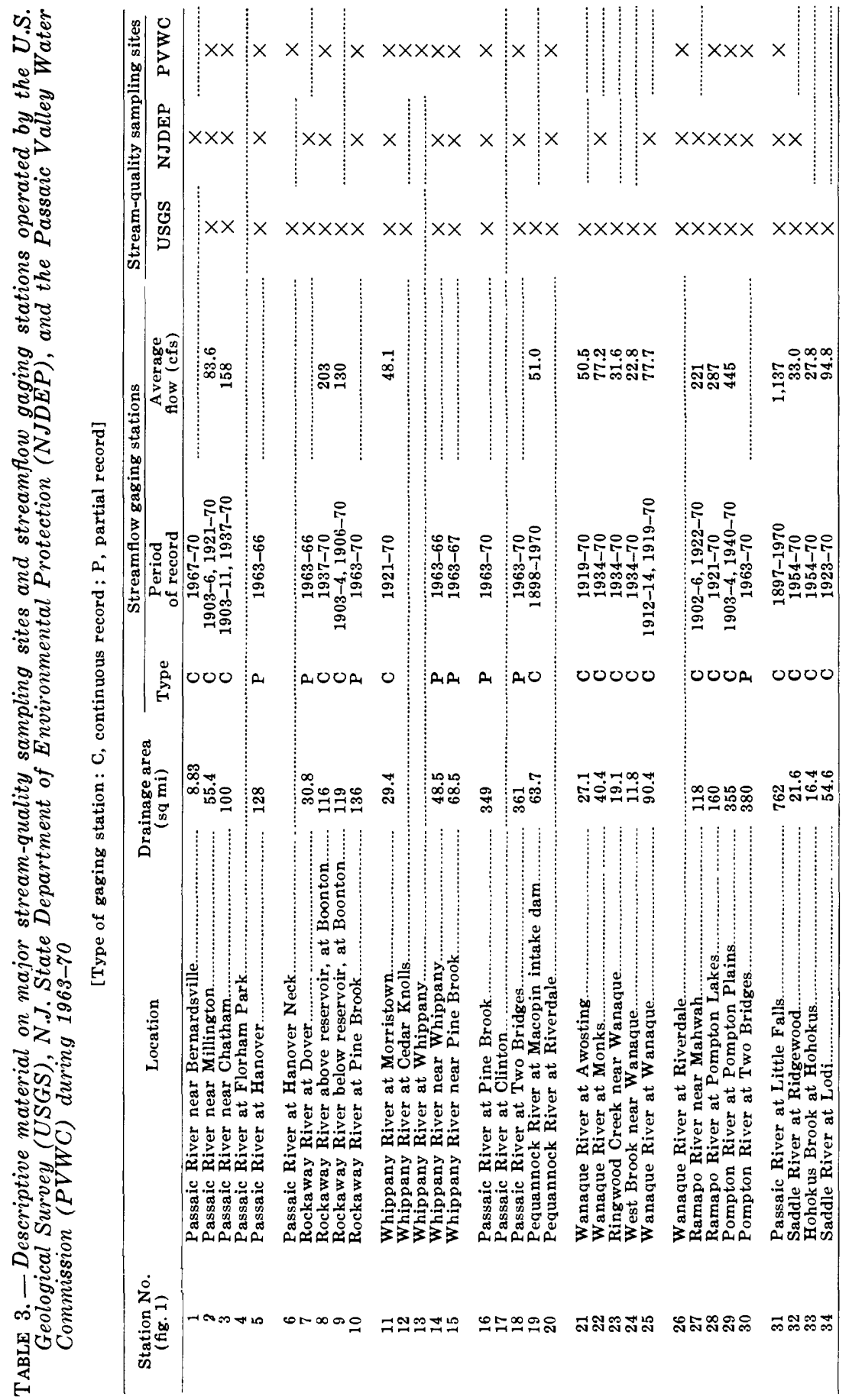


Water requirements are related to the number of people living in an area or using its water resources. According to the 1970 census (U.S. Bureau of the Census, 1971), the basin's population
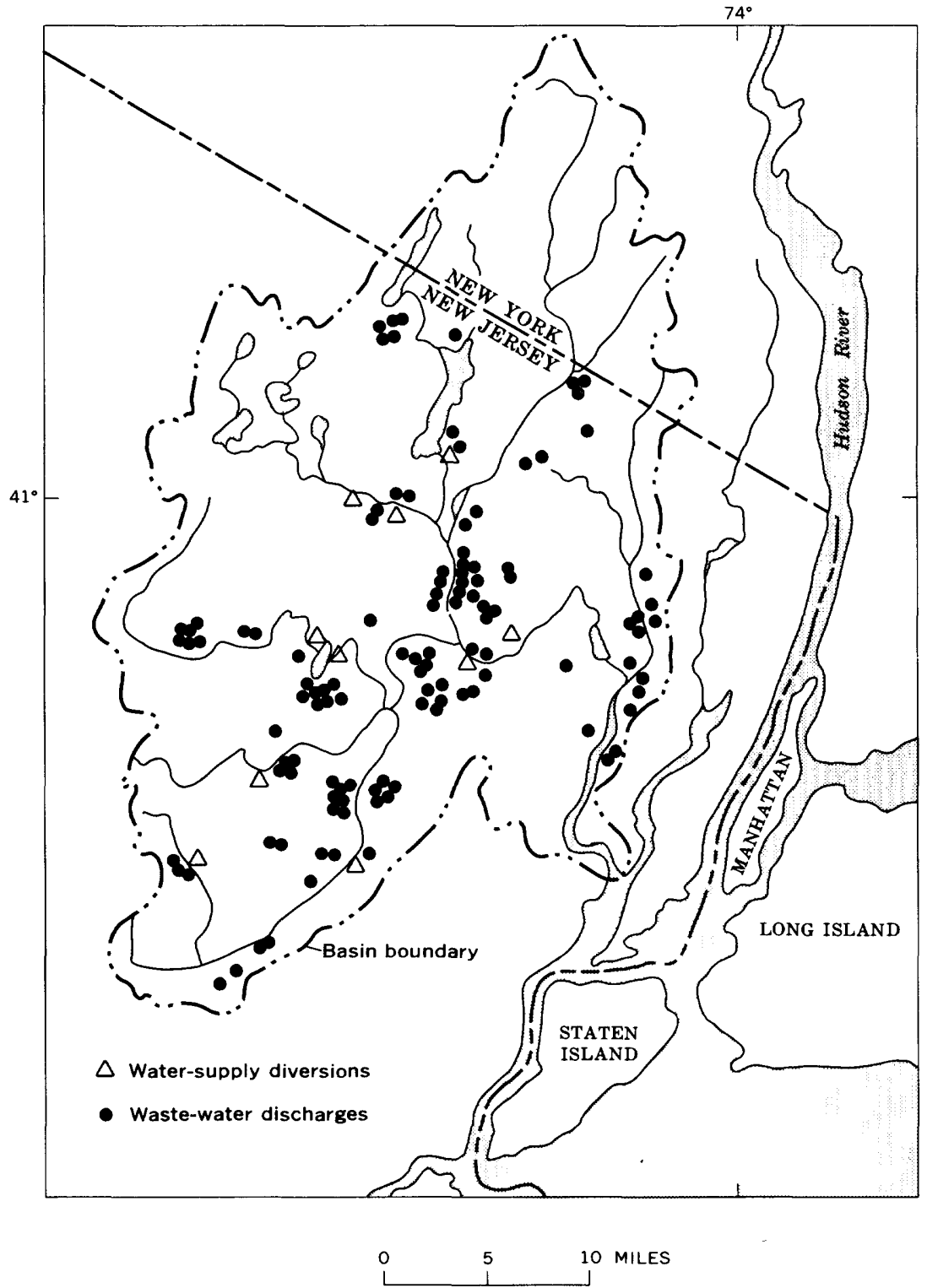

FIGURE 2. - Location of principal water-supply diversions and waste-water discharges during 1970. 
within New Jersey was slightly over 1.9 million persons in 1970 . This compares with 1.7, 1.4, and 1.2 million in 1960,1950, and 1940, respectively (U.S. Bureau of the Census, 1961). Much of this population was centered in the Paterson-Passaic-Clifton-Newark metropolitan complex near the river's mouth. Comparatively, total population in the State was about 7.1 million in 1970, 6.1 million in 1960, 4.8 million in 1950, and 4.2 million in 1940. About 27 percent of the State's population, therefore, lived within the basin's boundaries in 1970, as compared with about 28 percent in 1960 .

Projected population increases of about 75 percent from 1960 to 2000 (U.S. Army Corps Engineers and New Jersey Dept. Conserv. and Econ. Devel., 1968, p. 7) suggest a continued rapid expansion in the demands upon the basin's water resources. To meet these water demands, efficient and prudent water-resources management by action agencies is a necessity. The contents of this report can be used by such agencies as a source of information on the quality and quantity of the basin's surface-water resources. Additional information on the quantity and quality of waste-water effluents-such as that collected by the Environmental Protection Agency, the State Department of Environmental Protection, the New Jersey Water Resources Research Institute, and others-is needed by such action agencies in assessing the basin's water resources.

\section{STREAMFLOW CHARACTERISTICS}

The ultimate source of water in the Passaic River and its tributaries is precipitation. However, not all precipitation becomes streamflow. Evapotranspiration accounts for most of the water loss. Hely and others $(1961$, p. 6-7) estimated that water loss in the basin is 25-26 inches per year in the headwater areas near Millington and Chatham (fig. 1), 22-23 inches per year in the central and northeastern areas near Little Falls and Paterson, and 20 inches per year in the mountainous northwestern area.

\section{PRECIPITATION}

Climatologic data in the basin are reported as part of the State's northern climatologic division by the National Weather Service. This division is defined as that part of the State north of Mercer and Middlesex Counties. Recent comparative analyses by W. A. Sprigg (Dept. Meteorology, Rutgers-The State Univ., written commun., 1968) of precipitation data collected only within the basin with those collected in the division showed a 0.956 correlation coefficient. Thus, the variations in precipitation, as computed for the northern division, probably are representative of those for the basin. 
Average annual precipitation in the northern division, based on the standard reference period (World Meteorol. Organization, 1956), 1931-60, is 46.96 inches (U.S. Weather Bur., 1963). The lowest monthly average, 2.9 inches, normally occurs in February, and the highest, 4.9 inches, in August. Although precipitation in individual months may vary markedly from the average (fig. 3), the distribution is fairly uniform throughout the year-that is, 3-5 inches per month.

Because much of the following discussion on streamflow and stream quality is based on records collected between 1945 and 1970, a general understanding of the magnitude and extent of variations in precipitation during this period is important. These variations are shown on a cumulative-departure curve (fig. 4), which was developed from normal monthly precipitation records.

Five general trends are apparent: 1945-50, 1950-52, 1952-62, 1962-66, and 1966-70. The curve also shows several minor trends. A slope of almost zero is exhibited during 1945-50; thus, precipitation approximated normal conditions. The slope rises sharply from late 1950 to early 1953, thus indicating higher than normal precipitation. Subsequent to 1953 , the slope recedes gently until late 1961, thus indicating a slow change to less than normal precipitation patterns.
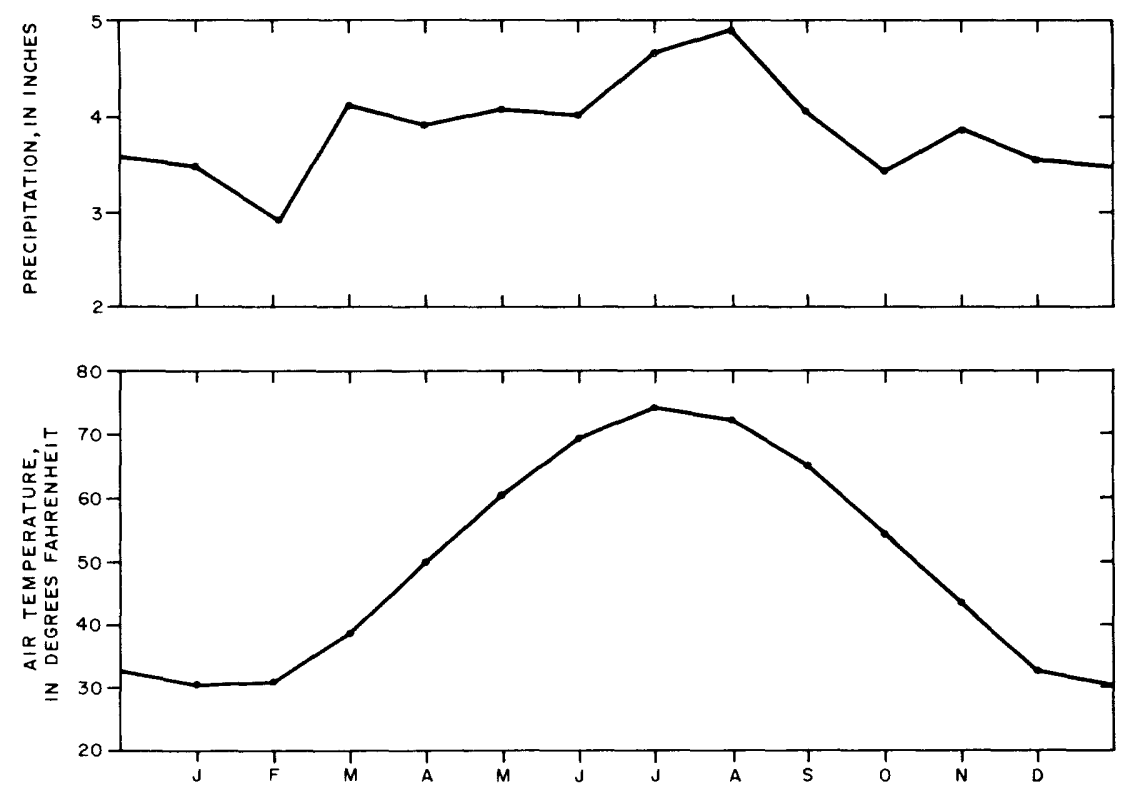

Figure 3. - Normal seasonal variations in precipitation and air temperature in the northern climatologic division of New Jersey. (Based on Natl. Weather Service recs., 1931-60.) 


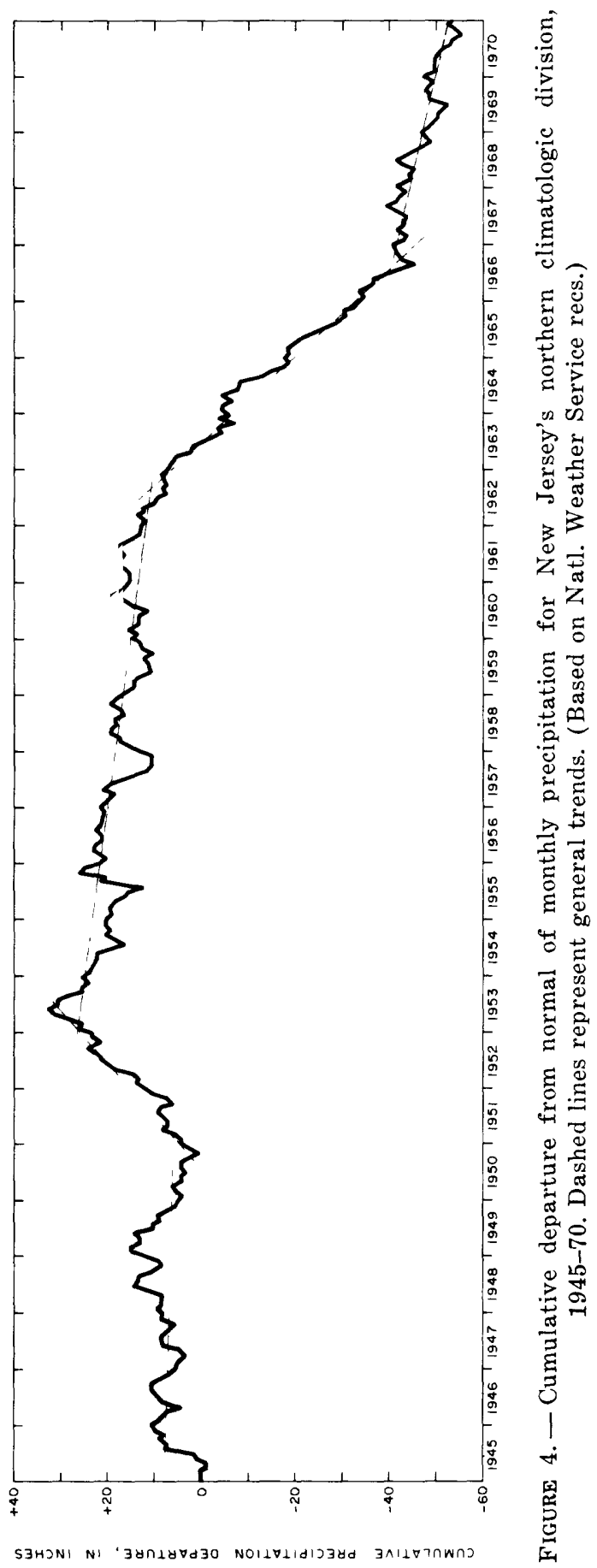


The sharply falling slope of the departure curve in late 1961 marks the beginning of 5 consecutive years of severe drought. This drought extended from Maine to Virginia and, at times, westward to Indiana and Michigan (Barksdale and others, 1966). The Palmer Index of Meteorologic Drought (Palmer, 1965) indicated that meteorologic drought in New Jersey began in August 1961 and ended in September 1966 (as computed by the State Climatologist, D. V. Dunlap, written commun., 1968). However, the drought's residual effects on streamflow and stream quality, both in the State as a whole and in the Passaic River basin in particular, were still evident for many months after the drought ended (Anderson and McCall, 1968).

The drought's intensity can be shown simply by comparing the normal annual precipitation of 46.96 incles in the northern division with each average annual precipitation given in table 4 .

TABLE 4. - Summary of precipitation data, in inches, 1945-70

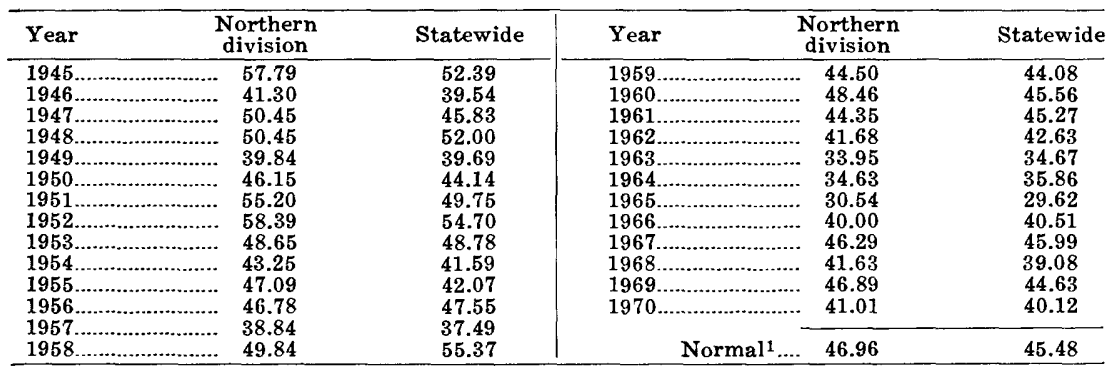

1 Based on the standard reference period, 1931-60.

Although precipitation was deficient for several 1- or 2-year periods before and including 1960 (1946, 1949-50, 1954, 1956-57, 1959), precipitation was below normal in each of the 10 subsequent years. Before this drought, the previous recorded minimum annual precipitation was 36.90 inches in 1930. Subsequently, a record low of 33.95 inches was established in 1963, only to be broken by the 30.54 inches recorded in 1965 . The worst year of the drought statewide, as measured by the Palmer Drought Index, was also 1965. Anderson and McCall (1968, p. 780) noted, in a comparison of precipitation deficiencies during 1961-66 in the three climatologic divisions of the State, that the northern division had the greatest deficiency, reaching a cumulative departure between August 1961 and August 1966 of about 1.3 times the expected normal yearly precipitation (or 61 in.). By comparison, precipitation deficiency reached about 0.9 of a normal year ( $41 \mathrm{in}$. in the southern division and about 0.8 of a normal year (29 in.) in the coastal division. Historic records suggest that droughts of 
this length and severity in this part of the United States have a recurrence interval of about once in 140 years (Palmer, 1967).

After the end of 1966, a slight downward slope of the departure curve indicates continuation of less than normal precipitation but not the deficiency observed during the preceding drought.

Interestingly, the maximum recorded (1929-70) annual precipitation in the northern division, in 1952, and the record low, in 1965 , were observed during the period upon which this report is based, 1945-70.

\section{STREAMFLOW}

Two methods or techniques have been used in this report for the presentation and analysis of streamflow data: flow-duration and moving-average analysis.

Flow-duration analysis involves the computation, based on daily mean discharge values, of the percentage of time during a given period in which specified discharge ranges are equaled or exceeded at a particular measuring site. Flow-duration curves (Searcy, 1959) were developed for eight gaging stations in the basin. A summary of the data obtained from these curves is tabulated in table 5. The curves were developed from previously published data (Laskowski, 1970, p. 28-74) and from computation of subsequent frequency data at these stations for October 1967 to September 1970.

Flow-duration curves for four different time periods 1898-1970, 1931-60, 1945-70, and 1961-66 - are presented in figure 5 for the Passaic River at Little Falls. Although the curves have scant hydrologic value because of regulation and diversions in the basin above the Little Falls gaging station, they are presented because they illustrate the general pattern of similar flowduration curves for other gaging stations in the basin and because they illustrate the flow duration at the farthest downstream station on the Passaic River main stem.

Changes in streamflow patterns with time can be observed by comparing flow-duration curves or values computed for different time periods. For example, the flow at Little Falls during the recent drought, 1961-66, can be compared with the other time periods plotted. Curves for the period of record, 1898-1970, for the standard reference period, 1931-60, and for the study period, 1945-70, are not very different. However, flows were significantly lower during the drought at all percentages of time less than 99 .

Comparison of data in table 5 for gaging stations other than Little Falls also indicates little variation in streamflow values for the different time periods, except for the high and low percentages of time. Values presented in this table can be used to construct curves similar to those in figure 5 for these stations. 
The second technique used to analyze streamflow data, moving averages, involves the sequential calculation and graphing of values obtained by averaging data for successive time periods. As used in this report, the moving average is on a 12-month cycle;

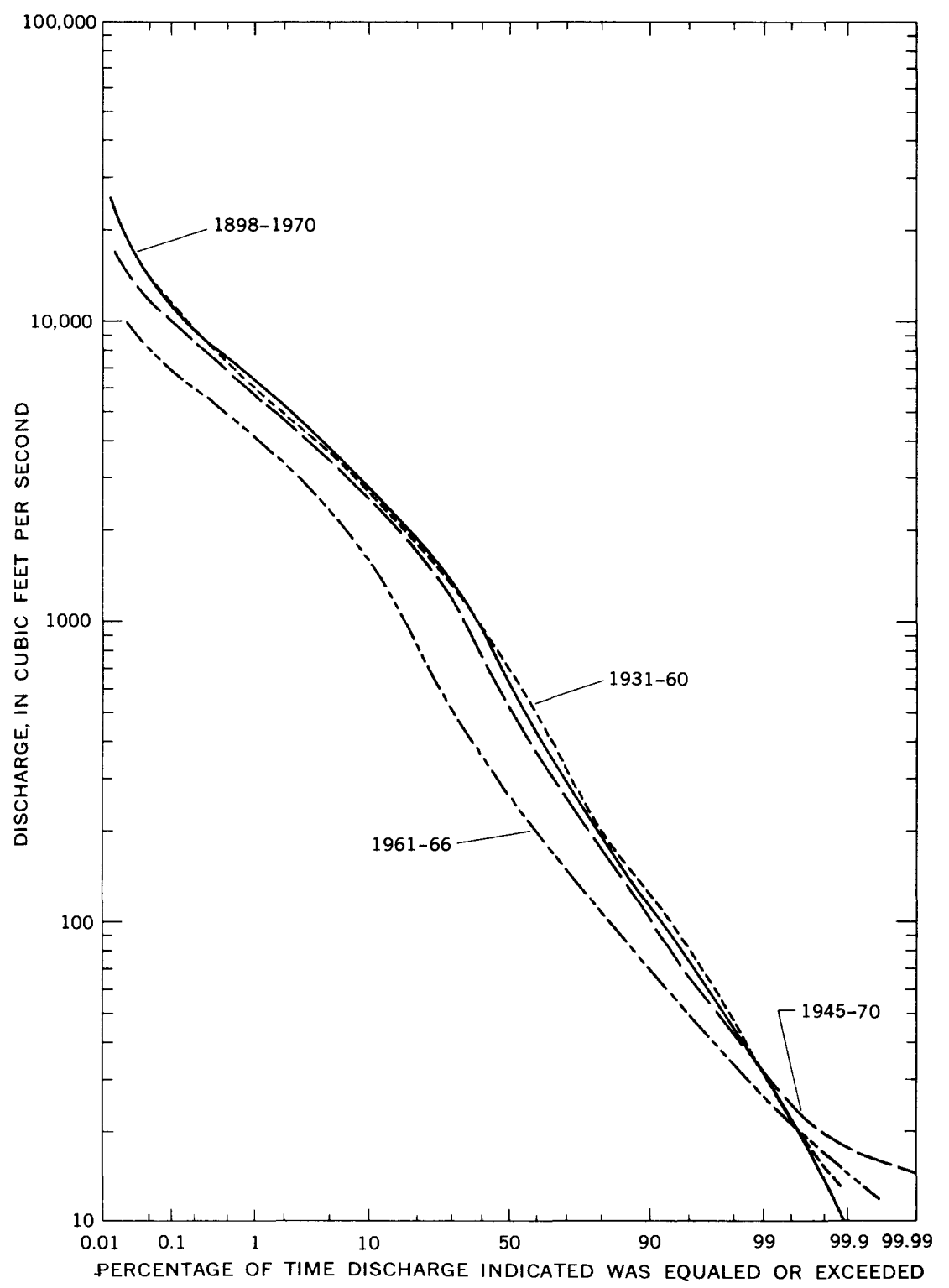

FIgURE 5. - Comparison of flow-duration curves developed for four time periods on the Passaic River at Little Falls. 


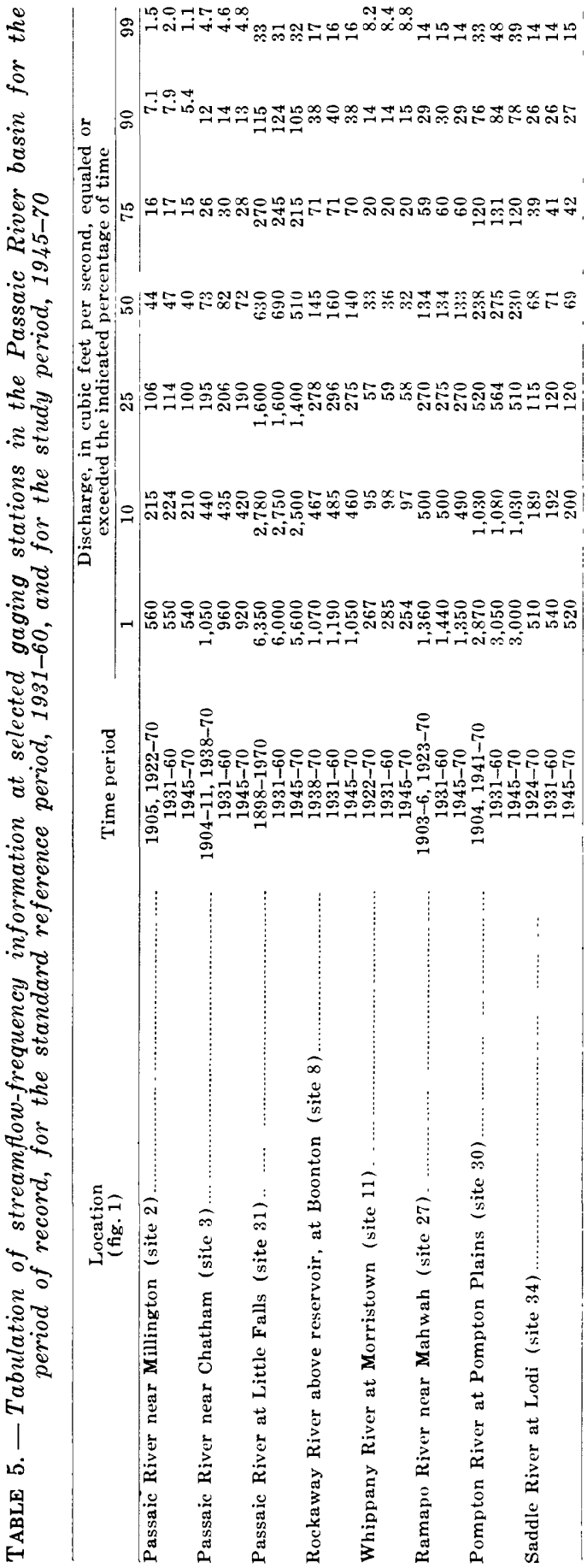


data points represent the preceding 12 months. Examples of curves produced by such analyses of mean monthly streamflow at several gaging stations in the Passaic River basin are illustrated in figure 6. Moving averages tend to dampen the extremes of short-term fluctuations in the chronological sequence of the parameter analyzed. Although moving-average analyses can be used to indicate general trends with time, they are seldom used for the determination of small variations, nor should they be used without additional serial-correlation analyses to give quantitative results. Thus, significant predictions or projections cannot be made with this technique.

A comparison of long-term average streamflow (table 3) with data presented in figure 6 indicates that there were six general periods in which streamflows generally exceeded the long-term average. These wet periods were in 1946-48, 1951-53, 1956, 1958, 1960-61, and 1967-68. Likewise, there were six general periods in which streamflows generally were less than the long-term average. These dry periods were in 1949-50, 1954-55, 1957, 1959, 1962-66, and 1969-70. In general, the highest flows were observed in 1952, and the lowest, in 1965. Comparison of streamflows in the Rockaway River below Boonton Reservoir with those observed above the reservoir demonstrate the influence of flow regulation and diversions.

\section{TIME-OF-TRAVEL MEASUREMENTS}

River systems, particularly those near metropolitan areas, transport, dilute, and assimilate waste waters discharged by industries and municipalities. Many contaminants introduced into river systems either are dissolved or are dispersed in a fine suspension and travel at the same rate as the stream that transports them. Waterpollution control and abatement work has demonstrated a need for more accurate knowledge of the movement of such materials in streams.

No truly satisfactory method for determination of the actual velocity of a water mass as it travels through a river system existed before the use of soluble dye tracers. Use of these dyes, technical aspects of their measurements and application, and interpretation of results have been reported previously by many authors, among whom are Pritchard and Carpenter (1960), Buchanan (1964), and Wilson (1968).

As mentioned in the introduction of this report, one of the project's objectives was to provide information on the amount of time required for a soluble contaminant to pass through finite lengths of the Passaic River system. Although complete documentation of time-of-travel characteristics of the entire project area was not 


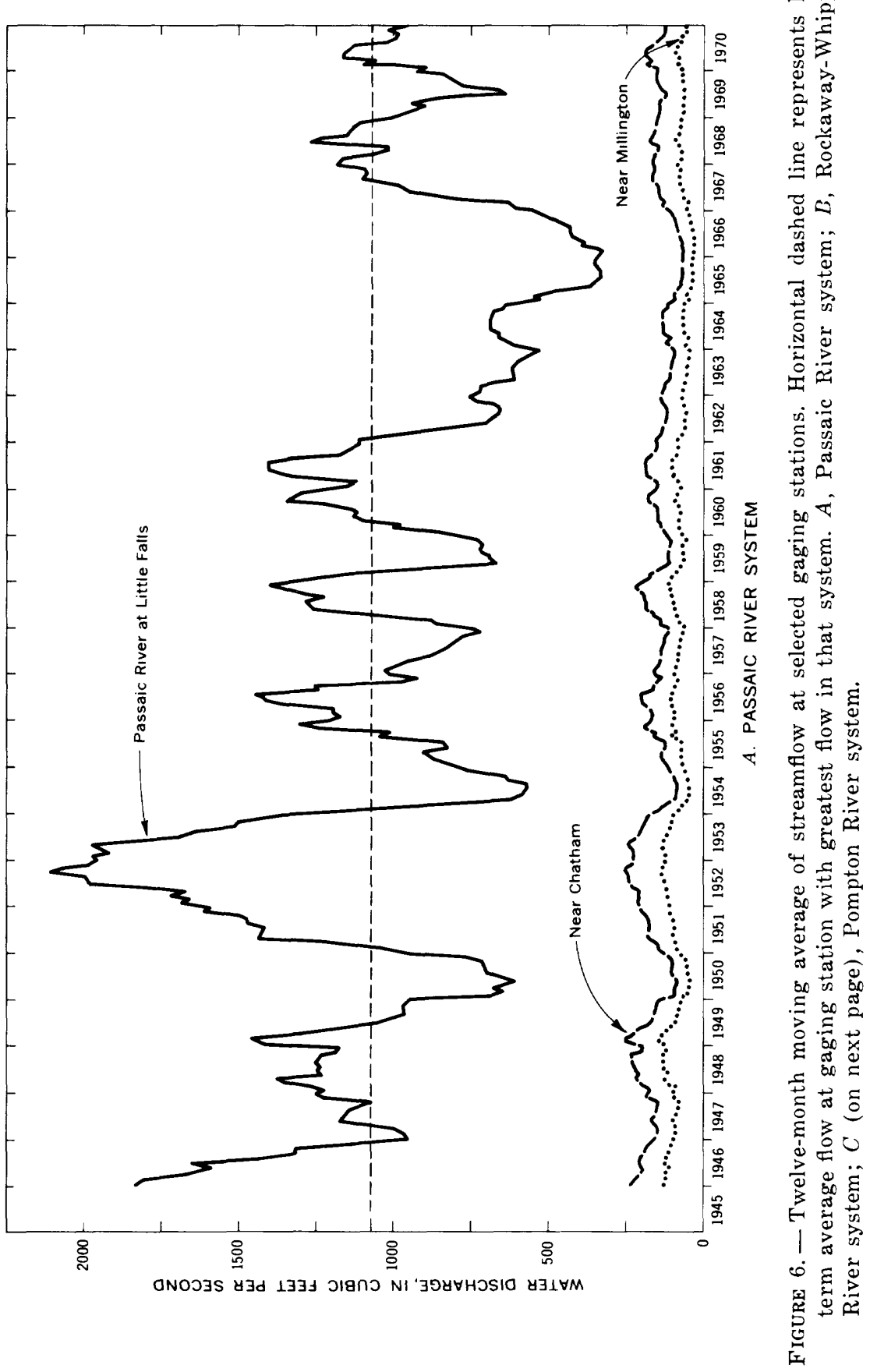




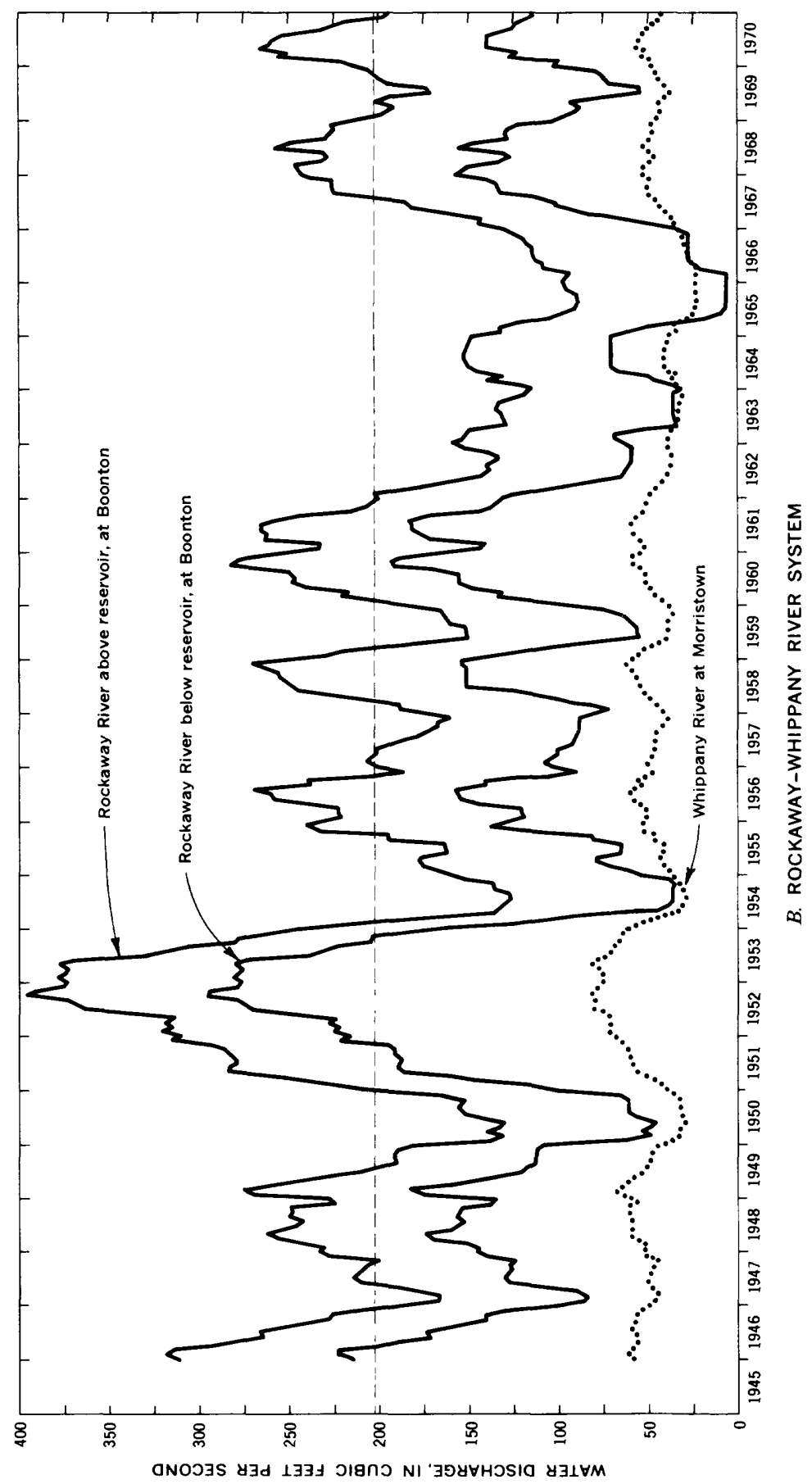




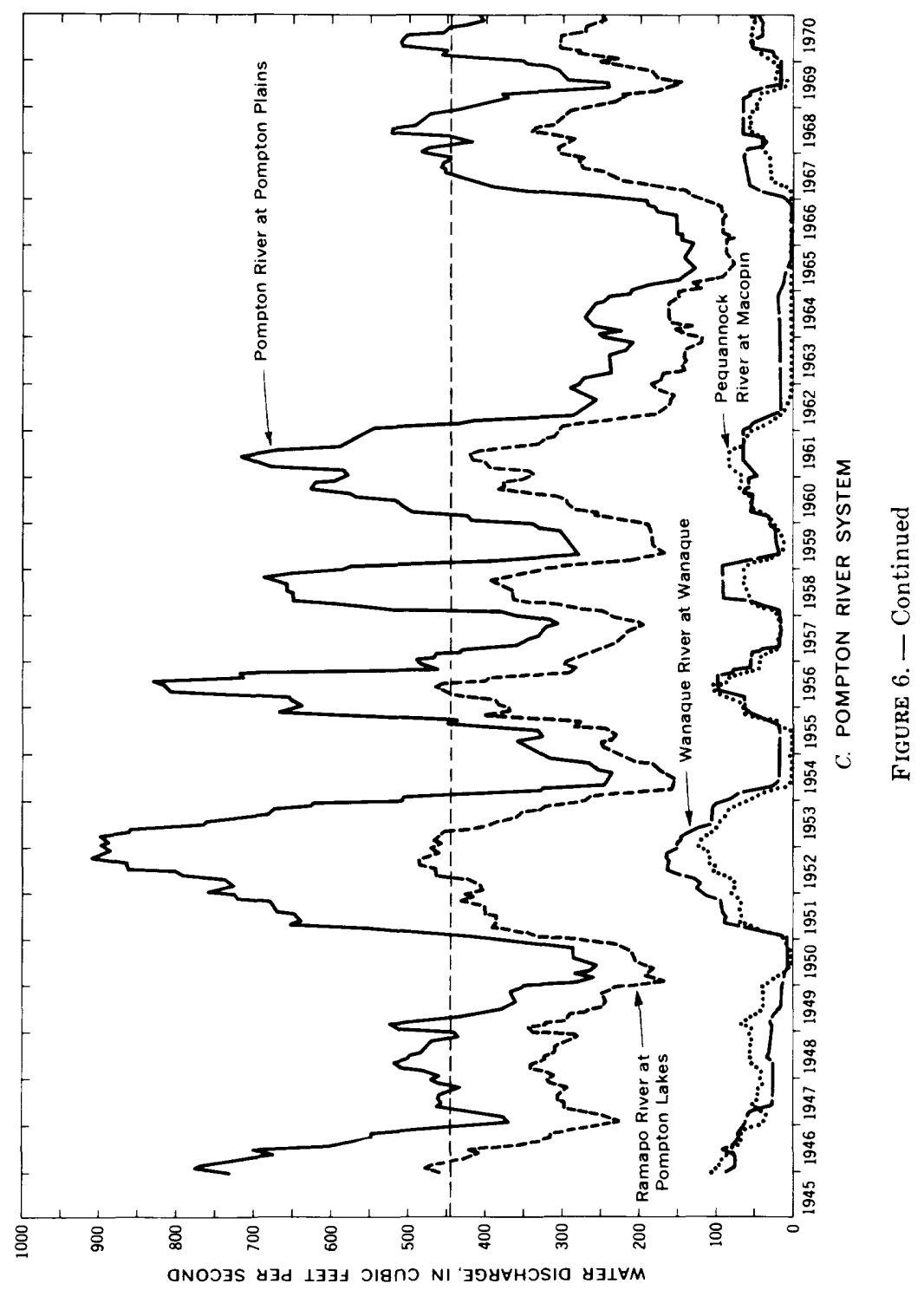


feasible during the life of the project, an effort was made to collect traveltime data by dye tracers on the major tributaries and on a major part of the main stem. Data were collected on a total of 83.9 miles of stream channel: 50.8 on the Passaic River, 20.6 on the Rockaway River, 5.7 on the Whippany River, and 6.8 on the Pompton River.

Initial time-of-travel measurements in the Passaic River basin were made in the upper Rockaway River system in collaboration with the Atomic Energy Commission and the U.S. Department of Defense. Results of these measurements were received from the principal investigator, E. L. Meyer (written commun., 1966), and are included in table 6 along with other time-of-travel information collected during the project. Two measurements were made on a reach extending from the confluence of Green Pond Brook and the Rockaway River at Dover (fig. 1, site 7) to the gaging station on the Rockaway River above Boonton Reservoir (site 8).

Measurements were made also on the Passaic River main stem between the Chatham gaging station (site 3 ) and the water-supply intake at Little Falls (site 31) ; on the Pompton River between the Pompton Plains gaging station (site 29) and the confluence with the Passaic River at Two Bridges (site 30); on the Whippany River between the Whippany Paper Board Co.'s Tri-Mill Secondary Waste Treatment Plant outfall (site 13) and Edwards Road bridge (site 15) about 0.3 miles above the confluence with the Rockaway River; on the Passaic River between Osborne Pond outlet (above site 1) near Basking Ridge and the Chatham gaging station (site 3); and on the Rockaway River at the gaging station below Boonton Reservoir (site 9) and Sharkey Road bridge (site 10 ) about 0.5 miles above the confluence with the Whippany River. Measurements usually were made during median to extreme low streamflow conditions, because data of this type are important to waste-water-assimilation studies.

Although no one dye cloud was traced through the entire Passaic River channel, a reasonable estimate of the total traveltimes was obtained by combining the observed traveltimes through each subreach, knowing that streamflow conditions were relatively stable over the measurement period. Thus, on the basis of data in table 6 , the peak concentration of a cloud produced by dye introduced at the Chatham gaging station is estimated to travel the entire 30.9 miles to the Little Falls water intakes in 119.5 hours (5 days) with a mean velocity of $0.41 \mathrm{fps}$ (feet per second) at high streamflow (June). Similarly, at extreme low streamflow (Sept.), it is estimated to travel the same distance in 313.7 hours (13 days) with a mean velocity of $0.17 \mathrm{fps}$. Traveltimes for the peak concen- 


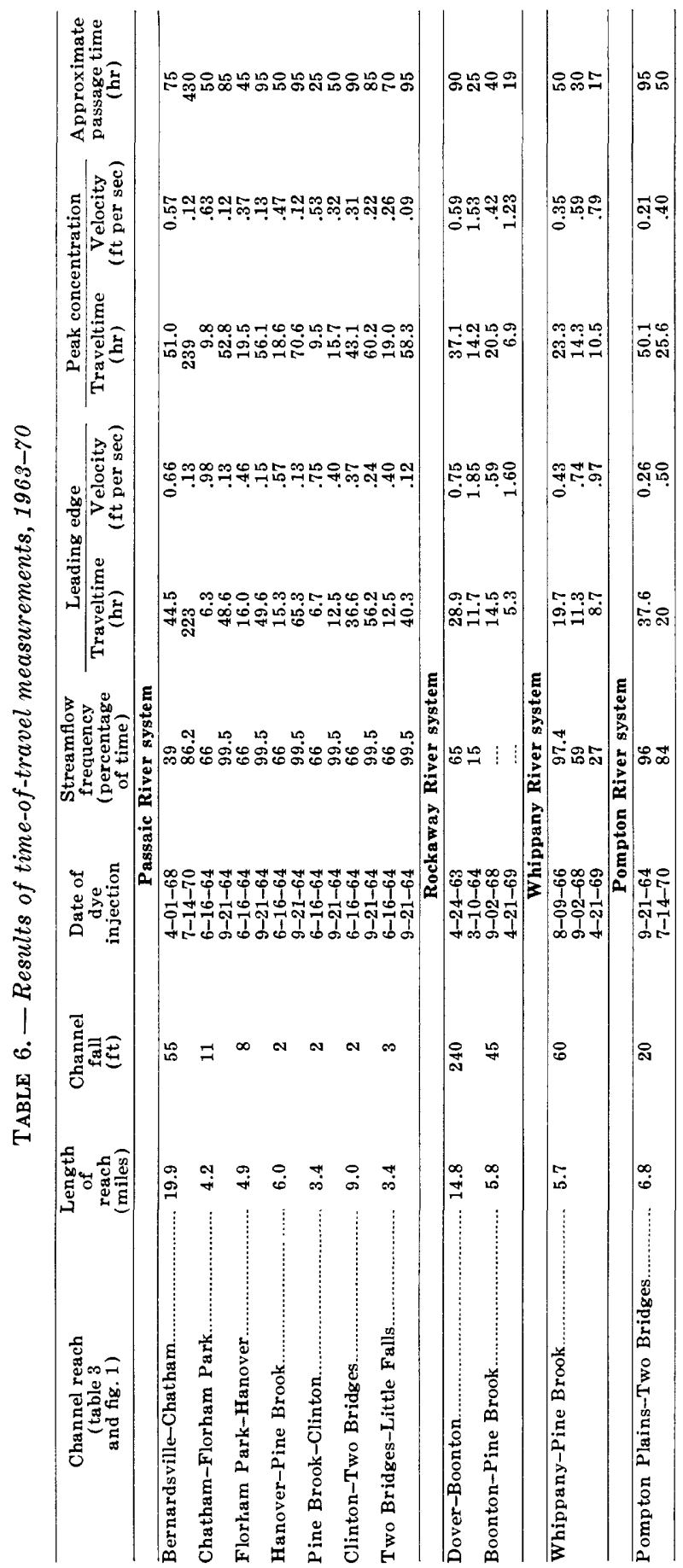


tration in other parts of the channel or in tributary streams, for the leading edge of the dye cloud, or for the approximate passage time can be computed in a similar manner.

The variability of traveltimes with streamflow is easily recognizable. Traveltimes and streamflow data collected on the Passaic River between Chatham (fig. 1, site 3) and Little Falls (site 31) and on the Pompton River between Pompton Plains (site 29) and Two Bridges (site 30) during the June and September 1964 measurements are plotted in figure 7 as a function of distance. As the two graphs on the left side of figure 7 show, a significant change in slope, and thus in traveltime, occurred during the September Passaic River measurement at the confluence with the RockawayWhippany River system (mile 15.1) and again at the Pompton River confluence (mile 27.5). However, little or no change was observed during the June measurement. The inflow of both tributary systems approximately doubled the main-stem discharge. Similarly, the two graphs on the right side of figure 7 show a significant change in slope in September at the point of confluence of the Pompton and Passaic River systems. Wilson and Forrest (1965, p. 11) previously reported that tributary inflow had little, if any, effect on traveltimes. Consequently, because of these previous observations and the consistency in proportions of tributary inflow to main stem discharge during both Passaic River measurements, some other factor must be assumed to cause the slope changes observed during the September measurements.

A possible explanation for the changes in the slopes is indicated by a comparison of observed velocities of peak dye concentrations (table 6) with the corresponding channel geometry. Velocities between Chatham and Pine Brook during the June measurement were the highest observed, ranging from 0.37 to $0.63 \mathrm{fps}$; whereas velocities for the entire reach, Chatham to Little Falls, ranged from 0.26 to 0.63 fps. However, during the September measurement, velocities in the upper reach were considerably lower, ranging from 0.12 to $0.13 \mathrm{fps}$; whereas velocities for the entire reach ranged from 0.09 to $0.32 \mathrm{fps}$.

In the 15.1-mile reach of the Passaic River between Chatham and Pine Brook, the fall is 1.4 feet per mile. Consequently, during the June measurement, the high velocities, and, thus, faster traveltimes, were probably related primarily to channel fall-that is, channel control. The September measurement was conducted during extreme low streamflow. The pool-and-riffle channel patternthat is, section control-which is predominant in this reach of the stream channel, probably produced the much lower velocities of 

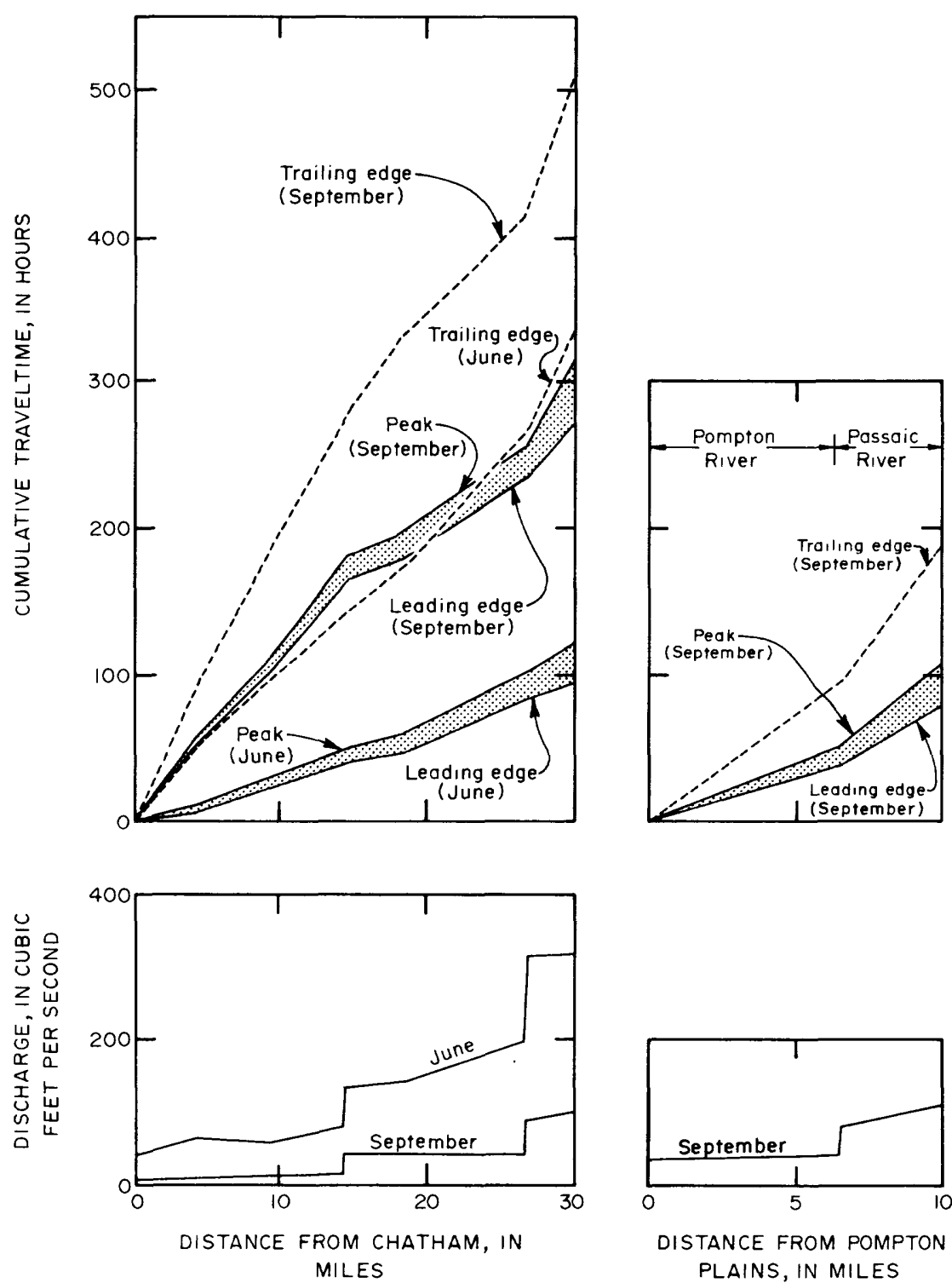

DISTANCE FROM POMPTON PLAINS, IN MILES

FIGURE 7. - Leading-edge, peak, and trailing-edge traveltime and streamflow data, Passaic River between Chatham and Little Falls, and Pompton and Passaic Rivers between Pompton Plains and Little Falls.

the dye cloud and, consequently, the slower traveltimes; hence, the greater rise in slope observed in figure 7.

Velocities of peak concentrations (table 6) observed in the Passaic River between Pine Brook and Two Bridges during the June 
measurement ranged from 0.31 to $0.53 \mathrm{fps}$. During the September measurement, they ranged from 0.22 to $0.32 \mathrm{fps}$. The Passaic River in this area flows in a tortuous channel through the Great Piece Meadows, which is an extensive low swampy area. The fall in this 12.4-mile stretch is 0.3 feet per mile. Velocities observed during the June measurement are generally lower than those observed in the Chatham to Pine Brook reach and reflect the lower channel slope. However, during the September measurement, the velocities are about double those observed in the reach immediately upstream, reflecting the absence of the pool-and-riffle effect. Traveltimes, therefore, are faster, and the change to a lesser slope is thus produced in figure 7.

Variations in the traveltime of the peak dye concentration during different streamflow conditions are shown in figure 8 for three reaches on the Passaic River main stem between Chatham and Little Falls. Each curve, of course, is based on only two measurements (table 6). Therefore, interpolation must be made with caution. For example, there may be breaks at points corresponding approximately to the changeover from section to channel control. A more reliable description would require additional data, particu-

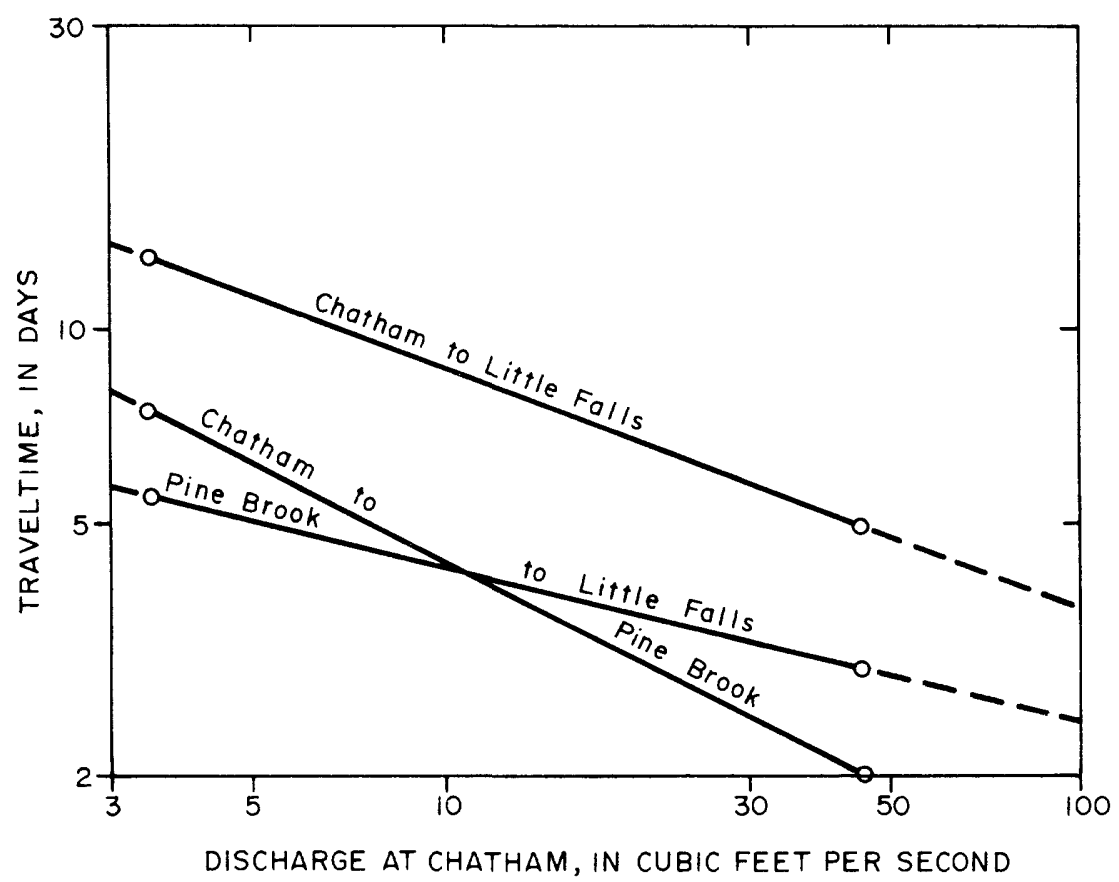

Figure 8. - Variations in traveltimes of peak dye concentration during different streamflow conditions. 
larly at higher streamflow patterns. This, however, should not hinder the use of these graphs to provide the best available estimate of traveltimes at low to medium discharge rates.

This particular type of plot, over a range of discharge conditions, can be of particular interest to the operator of a potablewater supply. Consider, for example, that a spill of some toxic material occurs near Chatham. Assuming the discharge at Chatham to be approximately $50 \mathrm{cfs}$, the Passaic Valley Water Commission's staff can predict (upper curve) that the peak concentration of the spill would travel the 30.9 miles to Little Falls in 4.5 days. A simple calculation predicts that the mean velocity of the peak concentration would be about $0.40 \mathrm{fps}$ at the assumed streamflow condition. At $10 \mathrm{cfs}$, the traveltime would be about 9 days, and the mean velocity, about 0.20 fps.

By use of the data in table 6, similar curves can be developed for traveltime of peak concentration in the other stream channels and for leading-edge and trailing-edge traveltimes, as well as traveltime of peak concentration, in any of the channels.

Another interpretation of time-of-travel information is presented in figure 9. From this illustration, the approximate time for the peak concentration of a soluble contaminant to travel between any two points on the Passaic River channel between

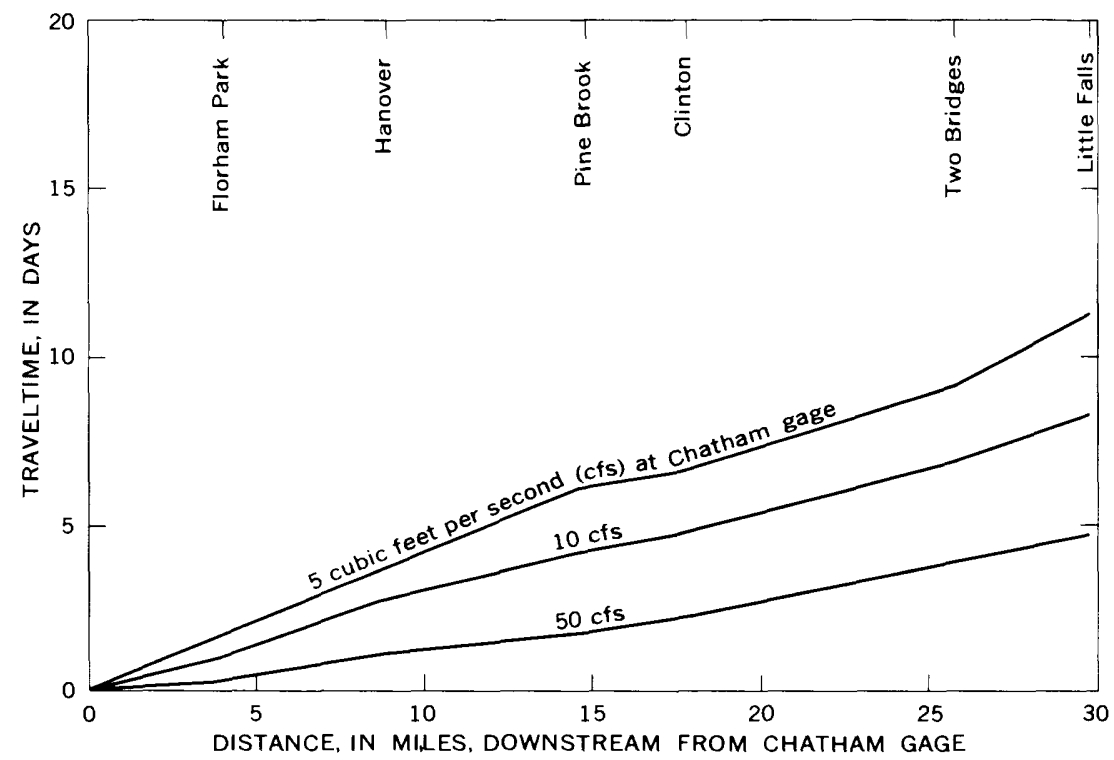

Figure 9. - Traveltime versus distance downstream from Chatham at selected streamflow rates observed at the Chatham gaging station. 
Chatham and Little Falls can be estimated if the discharge at Chatham is known.

Some effort was made during the measurements to investigate the effects of dispersion of the dye. Cross-sectional samples were taken during the June 1964 measurement on the Passaic River main stem to study lateral-dispersion characteristics. Data indicate that, although dye concentrations along the bank trailed those in the center, the magnitude and shape of the concentration curve at midstream and along the bank were similar. Vertical mixing occurred shortly after injection of the dye, especially because depths in the reaches under study rarely exceed 6 feet except in the Beatties Dam pool just upstream from the Little Falls sampling site. Thus, vertical and lateral dispersion of the dye was assumed to be nearly complete at the sampling sites.

The effects of longitudinal dispersion can be seen in figure 10 . This illustration shows the successive diminution with time and distance of a dye cloud produced by a single injection in April 1968 in the upper Passaic River system. The reduction in dye concentration at each successive site is not entirely due to dispersion characteristics, as indicated by the decrease in area under each curve. Some is due to dilution effects from tributary inflow, some to the loss of dye on streambed materials and vegetation, and some to the decay of the dye by photochemical and bacterial action.

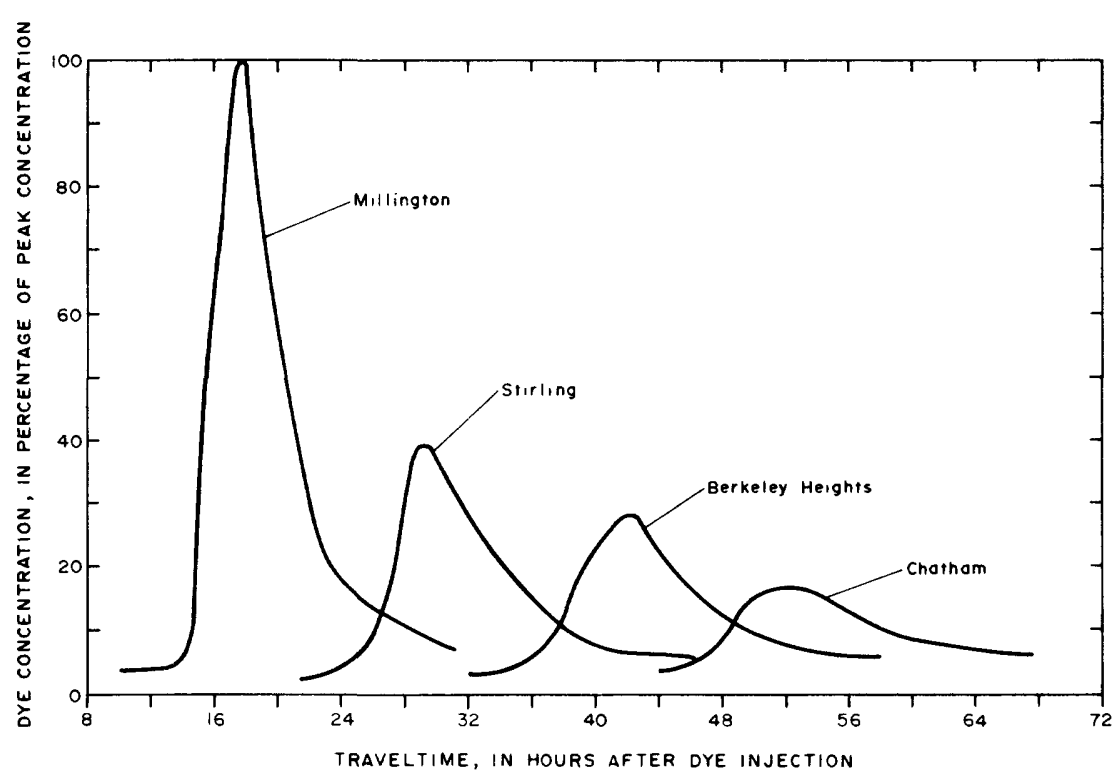

Figure 10. - Dispersion of a dye cloud with both time and distance. 


\section{WATER-QUALITY CHARACTERISTICS}

The findings of an analysis of regional variations and long-term and seasonal trends in water quality in the basin are described in this section. Emphasis is placed on chemical and biochemical water quality, because of the quantity of data available on these parameters. However, short discussions are presented on physical water quality where significant quantities of data were available.

\section{CHEMICAL CHARACTERISTICS}

Water is unable to remain entirely pure in its hydrologic cycle. As moisture condenses and falls through the atmosphere, it absorbs gases and picks up dust, bacteria, spores, and other particles. Consequently, as precipitation reaches the earth, it carries small quantities of dissolved and suspended matter. Although the dissolved-solids content of precipitation can be variable (an observation based on random chemical analyses of rainfall), in New Jersey it probably does not exceed $30 \mathrm{mg} / 1$ (milligrams per liter) except during a climatologic extreme, such as a hurricane.

Most water flowing in a New Jersey stream during extreme high flow is from direct overland runoff. Because this water has had little contact time with soluble materials, its solutes generally reflect the concentration and composition of precipitation. Consequently, the dissolved-solids content of New Jersey streams at extreme high flow is usually, but not always, at a minimum (Anderson and George, 1966, p. G7-G8).

Conversely, the dissolved-solids content of most streams during extreme low flow is generally at a maximum. During low flow, the natural flow is maintained almost entirely by ground-water inflow. Consequently, low-flow solutes reflect the concentration and composition of the ground-water inflow. This ground water generally has a higher solute content than does surface runoff because of its longer contact with soluble materials.

Under natural conditions, the dissolved-solids content of a stream during intermediate flow is a composite of both the quality of ground-water inflow and the quality of direct runoff and is regulated by the amount of streamflow contributed from each source.

The generalized relations between dissolved solids and streamflow at four main-stem sampling locations - Millington (fig. 1, site 2), Chatham (site 3), Two Bridges (site 18), and Little Falls (site 31) - are plotted in figure 11 to illustrate the variation of solutes with flow. Similar curves can be constructed for other sampling locations. An inverse relation between dissolved-solids content and streamflow is shown. Dissolved-solids and streamflow 


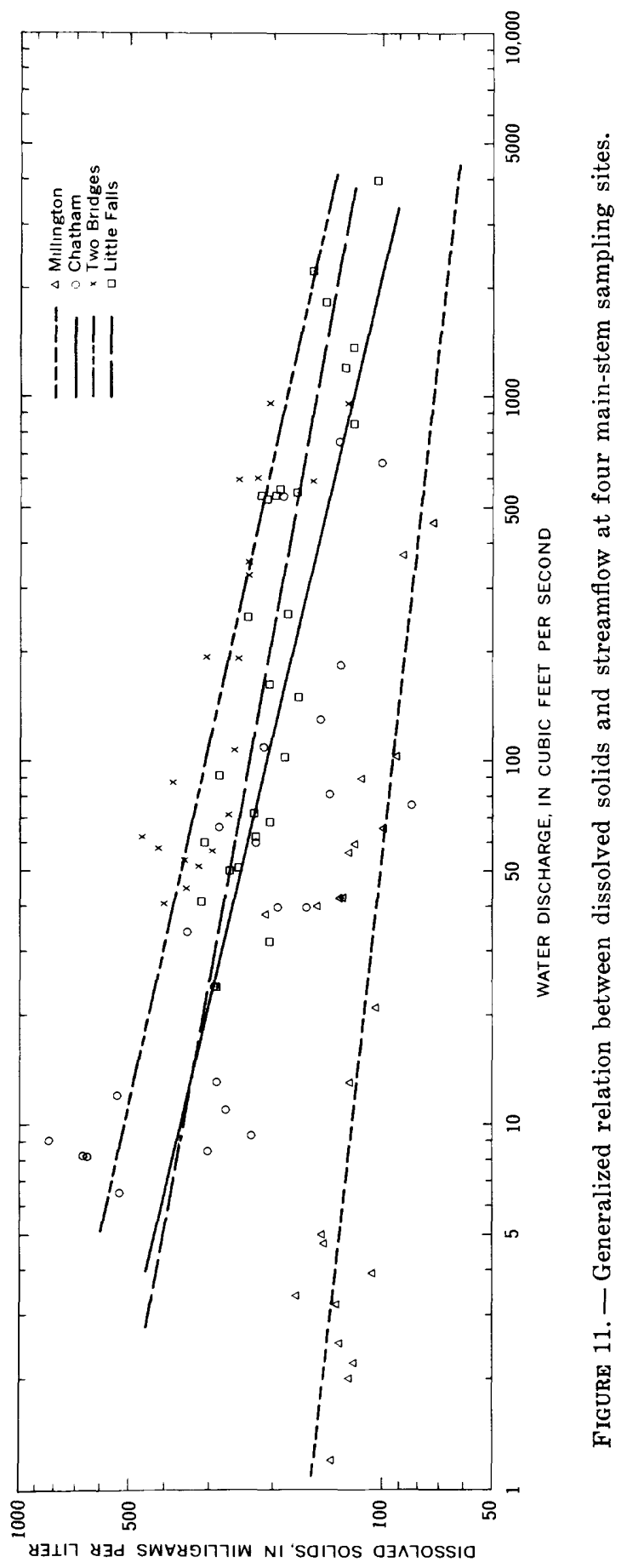


data collected at more than 100 sites during this study indicate that this is the common relation found in the basin, and indeed, Anderson and George (1966, p. G7) reported that it is characteristic of most streams in the State. The concentrations of calcium, magnesium, sodium, potassium, bicarbonate or alkalinity, sulfate, chloride, hardness, and suspended sediment also can be related significantly to streamflow at most sampling sites in the basin.

\section{REGIONAL VARIATIONS}

The relation between the dissolved-solids content and streamflow in a stream unaffected by man's activities should remain fairly consistent with time at a particular sampling site. Any changes in the dissolved-solids-streamflow relation that are likely to occur are those caused by relatively slow changes in climate.

The chemical character and the dissolved-solids content of streams above the influence of tide in various isochemical regions of the basin are summarized by the map and table in figure 12 . In the table, sodium and potassium ions are referred to as the alkali metals, whereas calcium and magnesium ions are referred to as the alkaline earths. The anions associated with carbonic acid - carbonate and bicarbonate ions-are referred to as alkalinity, whereas those associated with strong acids - sulfate, chloride, fluoride, and nitrate ions - are referred to as salinity. The amounts of other ions present are assumed to be insignificant.

These ion groupings indicate the types of water that prevail in various parts of the basin. A few streams in each isochemical region may not fall within these general limitations. The map was compiled from an analysis of water-quality data collected during low streamflow at over 80 sampling sites. Consequently, the water types mapped generally reflect the chemical quality of influent ground waters, which maintain the river system's base flows. However, man's waste-water discharges in parts of the basin have altered the natural dissolved-solids-streamflow relation.

The basin is about equally divided between the New England Upland section of the New England physiographic province and the Piedmont Lowland section of the Piedmont province (fig. 12). The topography in both provinces is characterized by low wellrounded hills and shallow valleys. The New England Upland section is mostly forested, except for scattered farmlands. The Piedmont Lowland section contains the densely populated and industrial metropolitan area of northeastern New Jersey and its adjacent suburban complexes.

Streams draining regions 1 and 2, which are largely in and include most of the New England Upland part of the basin (fig. 12), are low in dissolved-solids content, generally less than 


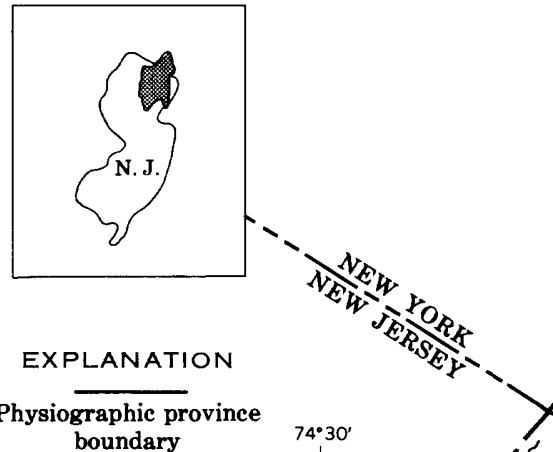

Physiographic province boundary

Isochemical-quality region boundary

4

Region designation
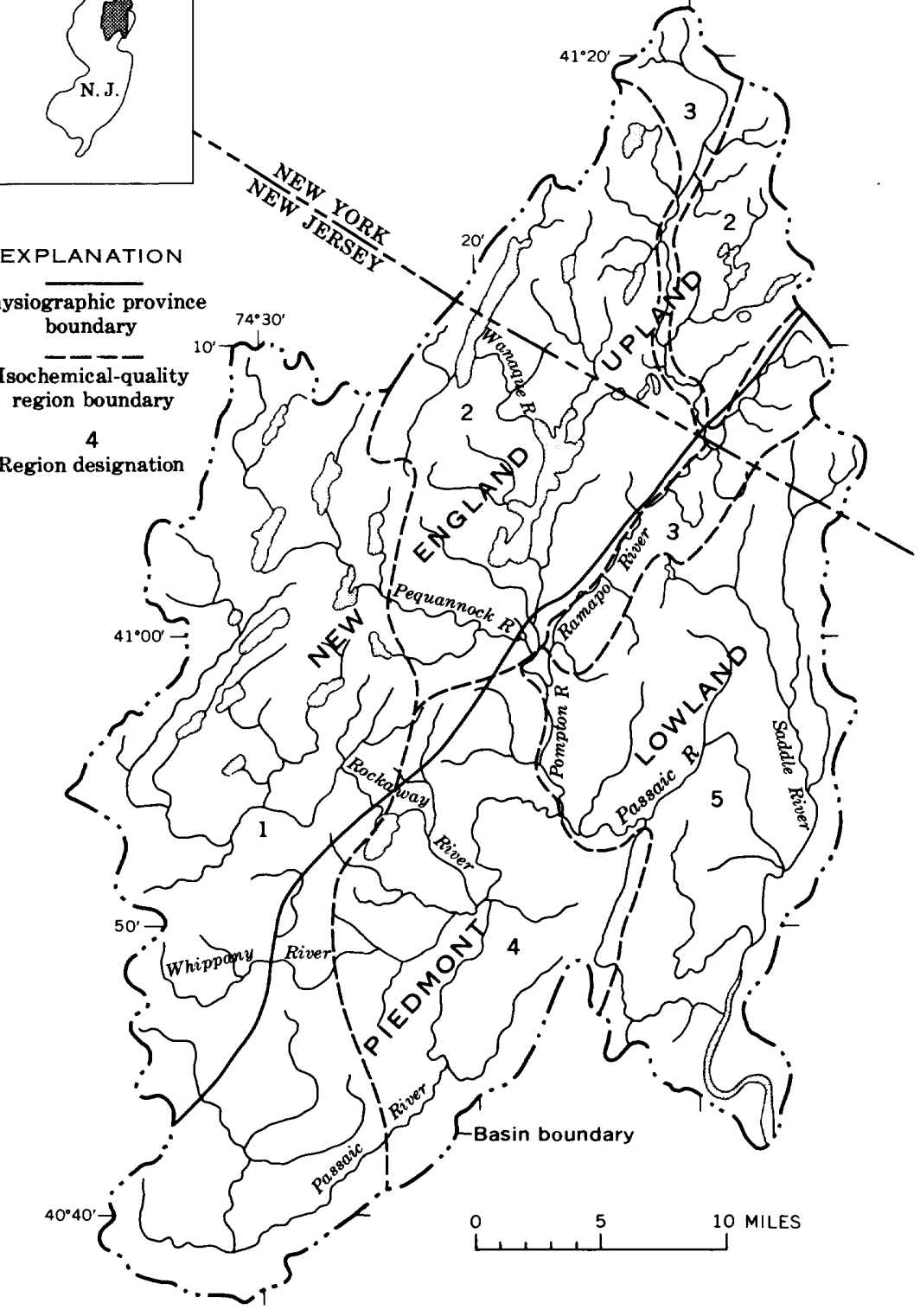

Chemical parameter

Estimated maximum dissolved solids ( $\mathrm{mg} / 1$ ) Percentage of total cations :

Alkali metals..

Alkaline earth

Percentage of total anions:

Alkalinity

Salinity.
200

20-50 $50-80$

50-80 20-50

\section{Isochemical regions}

$\begin{array}{cccc}2 & 3 & 4 & 5 \\ 150 & 400 & 300 & 400\end{array}$

$0-30 \quad 10-40 \quad 30-60 \quad 10-40$

$70-100 \quad 60-90 \quad 40-70 \quad 60-90$

$\begin{array}{llll}20-50 & 50-80 & 30-60 & 30-60 \\ 50-80 & 20-50 & 40-70 & 40-70\end{array}$ 
$200 \mathrm{mg} / \mathrm{l}$. Those draining region 2 have the lowest values. The predominant cations in both regions are the alkaline earths, which range from 50-80 percent in region 1 to $70-100$ percent in region 2. The predominant anions in these two regions, however, are different. About 50-80 percent of the anions in region 1 are those usually associated with alkalinity, mainly bicarbonate but also some carbonate; whereas about 50-80 percent of the anions in region 2 are those associated with salinity, principally sulfate but including minor amounts of chloride, fluoride, and nitrate. The main stem of the Ramapo River within New York State has been included as an extension of region 3 that cuts region 2 . The different chemical characteristics of the Ramapo River may reflect the influence of industrial and municipal waste-water discharges into the main stem, although this interpretation is based on few chemical-quality data.

Streams draining regions 3, 4, and 5, largely in the Piedmont Lowland part of the basin, have a higher dissolved-solids content than do those draining the New England Upland, usually exceeding $100 \mathrm{mg} / \mathrm{l}$ and sometimes exceeding $400 \mathrm{mg} / \mathrm{l}$. In these regions, too, the predominant cations are the alkaline earths. Except in region 4, the calcium plus magnesium composition of water in the streams exceeds 50 percent of the total cations. In region 4, the alkaline earths range from 40 to 70 percent. Consequently, the percentages (30-60) of alkali metals in this region are the highest observed in the basin. The predominant anions (50-80 percent) in region 3 are those associated with alkalinity. Carbonate concentrations were not observed in measureable amounts. The anions associated with salinity, principally sulfate and chloride but also nitrate and minor amounts of fluoride, are the predominant anions (40-70 percent) in regions 4 and 5 .

High and low major water-quality parameters at 18 sampling sites during 1962-70 are given in table 7. A comparison with analyses of samples collected in 1923-25 (table 1) indicates that the concentrations of many constituents have changed. In general, the concentration of the stream waters during the earlier period is similar to the minimum concentration during the later period. Consequently, the chemical quality of the earlier samples, which represent a wide range of streamflow, is comparable to the chemical quality of normal recent samples only during high streamflow-that is, when chemical concentrations are at a minimum.

FIgURE 12. - Relation between physiography and the prevalent chemical character and dissolved-solids content at low streamflow in the Passaic River basin. 
TABLE 7. - Maximum and minimum observations of

[Chemical analyses in

\begin{tabular}{|c|c|c|c|c|c|c|c|c|}
\hline $\begin{array}{l}\text { Location } \\
\text { (fig. 1) }\end{array}$ & $\begin{array}{l}\text { Max. } \\
\text { or } \\
\text { min. }\end{array}$ & $\begin{array}{l}\text { Num- } \\
\text { ber } \\
\text { of } \\
\text { analy- } \\
\text { ses }\end{array}$ & $\begin{array}{c}\text { Silica } \\
\left(\mathrm{SiO}_{2}\right)\end{array}$ & $\begin{array}{l}\text { Iron } \\
\text { ( } \mathrm{Fe})\end{array}$ & $\begin{array}{l}\text { Cal- } \\
\text { cium } \\
\text { (Ca) }\end{array}$ & $\begin{array}{l}\text { Magne- } \\
\text { sium } \\
(\mathrm{Mg})\end{array}$ & $\begin{array}{l}\text { Sodium } \\
\text { (Na) }\end{array}$ & $\begin{array}{l}\text { Potas } \\
\text { sium } \\
(\mathrm{K})\end{array}$ \\
\hline $\begin{array}{l}\text { Passaic River near } \\
\text { Millington (site 2). } \\
\text { Passaic River near } \\
\text { Chatham (site } 3 \text { ). } \\
\text { Passaic River at Hanover } \\
\text { (site 5). } \\
\text { Rockaway River above } \\
\text { reservoir, at Boonton } \\
\text { (site } 8 \text { ). }\end{array}$ & $\begin{array}{l}\text { Max. } \\
\text { Min. } \\
\text { Max. } \\
\text { Min. } \\
\text { Max. } \\
\text { Min. } \\
\text { Max. } \\
\text { Min. }\end{array}$ & $\begin{array}{l}45 \\
43 \\
24 \\
43\end{array}$ & $\begin{array}{c}20 \\
4.5 \\
19 \\
6.2 \\
19 \\
7.7 \\
12 \\
2.2\end{array}$ & $\begin{array}{c}5.6 \\
15.02 \\
.04 \\
3.1 \\
.12 \\
1.5 \\
.04\end{array}$ & $\begin{array}{l}34 \\
6.8 \\
43 \\
7.5 \\
42 \\
15 \\
24 \\
9.0\end{array}$ & $\begin{array}{l}10 \\
2.4 \\
15 \\
3.4 \\
15 \\
5.6 \\
12 \\
3.2\end{array}$ & $\begin{array}{c}25 \\
4.8 \\
314 \\
5.0 \\
170 \\
7.8 \\
11 \\
4.0\end{array}$ & $\begin{array}{r}36 \\
11^{.6} \\
10^{.9} \\
1.2 \\
3.0 \\
.5\end{array}$ \\
\hline $\begin{array}{l}\text { Rockaway River at } \\
\text { Pine Brook (site } 10)\end{array}$ & $\begin{array}{l}\text { Max. } \\
\text { Min. }\end{array}$ & 42 & $\begin{array}{r}24 \\
7.9\end{array}$ & $\begin{array}{l}1.4 \\
.05\end{array}$ & $\begin{array}{l}39 \\
10\end{array}$ & $\begin{array}{l}43 \\
4.4\end{array}$ & $\begin{array}{l}92 \\
5.3\end{array}$ & ${ }^{11} .9$ \\
\hline $\begin{array}{l}\text { Whippany River at } \\
\text { Morristown (site 11). } \\
\text { Whippany River near } \\
\text { Whippany (site 14). } \\
\text { Whippany River near } \\
\text { Pine Brook (site 15). } \\
\text { Passaic River at } \\
\text { Pine Brook (site 16). } \\
\text { Passaic River at } \\
\text { Two Bridges (site 18). }\end{array}$ & $\begin{array}{l}\text { Max. } \\
\text { Min. } \\
\text { Max. } \\
\text { Min. } \\
\text { Max. } \\
\text { Min. } \\
\text { Max. } \\
\text { Min. } \\
\text { Max. } \\
\text { Min. }\end{array}$ & $\begin{array}{l}44 \\
23 \\
42 \\
26 \\
55\end{array}$ & $\begin{array}{l}20 \\
12 \\
33 \\
10 \\
26 \\
7.2 \\
23 \\
9.2 \\
22 \\
8.4\end{array}$ & $\begin{array}{l}8.0 \\
.07 \\
1.6 \\
.23 \\
2.1 \\
.10 \\
1.9 \\
.23 \\
2.7 \\
.12\end{array}$ & $\begin{array}{l}29 \\
7.5 \\
39 \\
14 \\
50 \\
16 \\
35 \\
16 \\
34 \\
13\end{array}$ & $\begin{array}{l}12 \\
3.5 \\
18 \\
4.1 \\
85 \\
5.1 \\
19 \\
5.6 \\
17 \\
4.6\end{array}$ & $\begin{array}{c}32 \\
7.6 \\
113 \\
15 \\
137 \\
12 \\
102 \\
9.7 \\
88 \\
9.2\end{array}$ & $\begin{array}{l}4.4 \\
1.2 \\
7.2 \\
2.5 \\
6.5 \\
1.8 \\
7.8 \\
1.3 \\
7.7 \\
1.1\end{array}$ \\
\hline $\begin{array}{l}\text { Pequannock River at } \\
\text { Macopin intake dam } \\
\text { (site } 19 \text { ). }\end{array}$ & $\begin{array}{l}\text { Max. } \\
\text { Min. }\end{array}$ & 17 & $\begin{array}{l}19 \\
4.4\end{array}$ & $\begin{array}{l}.93 \\
.01\end{array}$ & 20 & $\begin{array}{l}7.4 \\
2.0\end{array}$ & $\begin{array}{l}30 \\
3.5\end{array}$ & $\begin{array}{r}1.6 \\
.0\end{array}$ \\
\hline $\begin{array}{l}\text { Wanaque River at } \\
\text { Wanaque (site 25). } \\
\text { Ramapo River near } \\
\text { Mahwah (site 27). } \\
\text { Ramapo River at } \\
\text { Pompton Lakes (site 28). }\end{array}$ & $\begin{array}{l}\text { Max. } \\
\text { Min. } \\
\text { Max. } \\
\text { Min. } \\
\text { Max. } \\
\text { Min. }\end{array}$ & $\begin{array}{l}23 \\
28 \\
20\end{array}$ & $\begin{array}{c}9.0 \\
1.9 \\
9.1 \\
4.7 \\
86 \\
1.4\end{array}$ & $\begin{array}{r}3.1 \\
.00 \\
.95 \\
.01 \\
1.2 \\
.10\end{array}$ & $\begin{array}{l}18 \\
8.8 \\
40 \\
11 \\
28 \\
9.8\end{array}$ & $\begin{array}{r}5.4 \\
2.6 \\
14 \\
3.6 \\
8.3 \\
3.5\end{array}$ & $\begin{array}{c}7.8 \\
3.6 \\
29 \\
7.0 \\
17 \\
5.2\end{array}$ & $\begin{array}{r}1.5 \\
.2 \\
2.9 \\
.2 \\
1.7 \\
.5\end{array}$ \\
\hline $\begin{array}{l}\text { Pompton River at } \\
\text { Pompton Plains } \\
\text { (site 29) }\end{array}$ & $\begin{array}{l}\text { Max. } \\
\text { Min. }\end{array}$ & 30 & $\begin{array}{l}10 \\
4.0\end{array}$ & $\begin{array}{l}1.0 \\
.06\end{array}$ & $\begin{array}{l}27 \\
13\end{array}$ & $\begin{array}{l}7.5 \\
3.9\end{array}$ & $\begin{array}{r}28 \\
7.8\end{array}$ & $\begin{array}{r}2.1 \\
.6\end{array}$ \\
\hline $\begin{array}{l}\text { Pompton River at } \\
\text { Two Bridges (site } 30 \text { ). } \\
\text { Passaic River at } \\
\text { Little Falls (site } 31 \text { ). } \\
\text { Saddle River at Lodi } \\
\text { (site 34). }\end{array}$ & $\begin{array}{l}\text { Max. } \\
\text { Min. } \\
\text { Max. } \\
\text { Min. } \\
\text { Max. } \\
\text { Min. }\end{array}$ & $\begin{array}{l}51 \\
47 \\
29\end{array}$ & $\begin{array}{c}13 \\
4.1 \\
15 \\
7.6 \\
16 \\
3.9\end{array}$ & $\begin{array}{c}1.6 \\
.03 \\
2.5 \\
.00 \\
1.4 \\
.03\end{array}$ & $\begin{array}{c}28 \\
9.8 \\
33 \\
11 \\
56 \\
13\end{array}$ & $\begin{array}{c}13 \\
3.5 \\
13 \\
4.1 \\
20 \\
2.7\end{array}$ & $\begin{array}{c}24 \\
7.7 \\
56 \\
7.6 \\
42 \\
11\end{array}$ & $\begin{array}{r}3.0 \\
.5 \\
5.2 \\
1.2 \\
6.2 \\
1.6 \\
\end{array}$ \\
\hline
\end{tabular}

Note that at most sites the concentrations of sodium, potassium, bicarbonate, sulfate, chloride, and nitrate ions have increased. Although techniques of chemical analyses changed between these two observation periods, $1923-25$ and 1962-70, the increase in concentration is, undoubtedly, significant and is not related to changes in techniques. Comparison with unpublished chemicalquality data relating to these sampling sites furnished by the State Department of Environmental Protection suggests the same conclusion, that concentrations of most ions have increased with time.

The concentration of trace elements, which does not generally exceed $1 \mathrm{mg} / \mathrm{l}$ in natural waters, was measured at nine sampling sites during 1962-70. Maximum and minimum concentrations of the individual trace elements are given in table 8 . The samples were analyzed by spectrographic methods and techniques described by Barnett and Mallory (1971). 
water-quality parameters by the U.S. Geological Survey, 196פ-70

milligrams per liter]

\begin{tabular}{|c|c|c|c|c|c|c|c|c|c|c|}
\hline \multirow{2}{*}{$\begin{array}{c}\text { Bicar- } \\
\text { bonate } \\
\text { ( } \mathrm{HCO} 3)\end{array}$} & \multirow{2}{*}{$\begin{array}{c}\text { Sul- } \\
\text { fate } \\
\left(\mathrm{SO}_{4}\right)\end{array}$} & \multirow{2}{*}{$\begin{array}{l}\text { Chlo- } \\
\text { ride } \\
\text { (Cl) }\end{array}$} & \multirow{2}{*}{$\begin{array}{l}\text { Fluo- } \\
\text { ride } \\
\text { (F) }\end{array}$} & \multirow{2}{*}{$\begin{array}{c}\mathrm{Ni}- \\
\text { trate } \\
\left(\mathrm{NO}_{3}\right)\end{array}$} & \multirow{2}{*}{$\begin{array}{c}\text { Dis- } \\
\text { solved } \\
\text { solids } \\
\text { (residue } \\
\text { at } \\
180^{\circ} \mathrm{C} \text { ) }\end{array}$} & \multicolumn{2}{|c|}{$\begin{array}{l}\text { Hardness } \\
\text { as } \mathrm{CaCO}_{3}\end{array}$} & \multirow{2}{*}{$\begin{array}{l}\text { Specific } \\
\text { conduct- } \\
\text { ance } \\
\text { (micro- } \\
\text { mhos at } \\
25^{\circ} \mathrm{C} \text { ) }\end{array}$} & \multirow[b]{2}{*}{$\mathrm{pH}$} & \multirow[b]{2}{*}{ Color } \\
\hline & & & & & & $\begin{array}{l}\text { Calcium, } \\
\text { magne- } \\
\text { sium }\end{array}$ & $\begin{array}{l}\text { Noncar- } \\
\text { bonate }\end{array}$ & & & \\
\hline 89 & 102 & 31 & 0.3 & 3.7 & 279 & 107 & 91 & 479 & 9.0 & 130 \\
\hline 14 & 10 & 6.0 & .0 & .2 & 72 & 27 & 0 & 99 & 5.7 & 5 \\
\hline 217 & 90 & 465 & .5 & 19 & 823 & $17 \overline{7}$ & 85 & 1850 & 7.9 & 50 \\
\hline 14 & 23 & 4.0 & .0 & .4 & 83 & 33 & 0 & 108 & 6.2 & 3 \\
\hline 246 & 85 & 218 & .8 & 26 & 580 & 150 & 82 & 1120 & 7.1 & 55 \\
\hline 16 & 27 & 10 & .1 & .4 & 140 & 41 & 0 & 133 & 6.1 & 3 \\
\hline 95 & 32 & 24 & .4 & 4.5 & 149 & 110 & 37 & 256 & 8.0 & 30 \\
\hline 22 & 17 & 6.1 & .0 & .6 & 75 & 37 & 0 & 104 & 6.4 & 2 \\
\hline $\begin{array}{r}310 \\
98\end{array}$ & 127 & 62 & 1.6 & 72 & 474 & 155 & 83 & 832 & 8.2 & 70 \\
\hline 28 & 21 & 9.5 & .0 & .3 & 106 & 46 & 0 & 142 & 6.3 & 3 \\
\hline 106 & 55 & 31 & .3 & 13 & 224 & 115 & 42 & 359 & 8.2 & 25 \\
\hline 26 & 20 & 9.0 & .0 & 2.1 & 105 & 33 & 0 & 148 & 6.5 & 3 \\
\hline 300 & 157 & 94 & 1.4 & 30 & 570 & 162 & 83 & 865 & 8.2 & 100 \\
\hline 16 & 9.0 & 2.5 & .0 & .2 & 136 & 52 & 0 & 207 & 6.5 & 5 \\
\hline 457 & 144 & 67 & 1.2 & 24 & 394 & 175 & 135 & 762 & 8.5 & 100 \\
\hline 30 & 25 & 10 & .0 & .2 & 124 & 61 & 0 & 201 & 6.1 & 3 \\
\hline 202 & 96 & 92 & .7 & 30 & 452 & 161 & 72 & 806 & 8.0 & 65 \\
\hline 24 & 28 & 12 & .0 & .6 & 136 & 47 & 0 & 152 & 6.3 & 3 \\
\hline 197 & 100 & 103 & .8 & 40 & 466 & 155 & 89 & 784 & 8.1 & 60 \\
\hline 22 & 21 & 12 & .0 & .4 & 125 & 46 & 0 & 146 & 6.0 & 3 \\
\hline 72 & 63 & 30 & .2 & 6.1 & 193 & 76 & 39 & 303 & 7.9 & 15 \\
\hline 14 & 14 & 6.4 & .0 & .0 & 60 & 21 & 8 & 86 & 6.6 & 3 \\
\hline 49 & 29 & 16 & .2 & 6.3 & 108 & 70 & 37 & 173 & 7.6 & 15 \\
\hline 20 & 14 & 5.0 & .0 & .4 & 53 & 34 & 13 & 96 & 6.2 & 2 \\
\hline 130 & 42 & 40 & .7 & 10 & 224 & 158 & 58 & 392 & 8.2 & 75 \\
\hline 24 & 19 & 12 & .0 & .6 & 89 & 43 & 22 & 138 & 6.6 & 2 \\
\hline 92 & 30 & & .2 & 5.0 & 164 & 102 & 40 & 279 & 8.1 & 25 \\
\hline 23 & 21 & 8.4 & .0 & 1.2 & 84 & 52 & 21 & 141 & 6.3 & 2 \\
\hline $\begin{array}{l}77 \\
24\end{array}$ & $\begin{array}{l}64 \\
22\end{array}$ & $\begin{array}{c}24 \\
8.6\end{array}$ & .2 & $\begin{array}{r}8.6 \\
.2\end{array}$ & $\begin{array}{r}191 \\
78\end{array}$ & $\begin{array}{l}94 \\
39\end{array}$ & $\begin{array}{l}43 \\
20\end{array}$ & $\begin{array}{l}306 \\
126\end{array}$ & $\begin{array}{l}7.8 \\
6.5\end{array}$ & $\begin{array}{r}18 \\
1\end{array}$ \\
\hline 72 & 62 & 37 & .3 & 10 & 202 & 109 & 54 & 325 & 8.1 & 25 \\
\hline 23 & 22 & 9.5 & .0 & 1.5 & 84 & 39 & 20 & 124 & 5.8 & 1 \\
\hline 112 & 78 & 60 & .5 & 25 & 311 & 130 & 75 & 542 & 8.0 & 35 \\
\hline 22 & 26 & 11 & .0 & .4 & 103 & 45 & 10 & 143 & 6.1 & 3 \\
\hline 159 & 59 & 65 & .5 & 32 & 395 & 217 & 96 & 625 & 8.5 & 30 \\
\hline 31 & 20 & 17 & .0 & 1.0 & 102 & 44 & 18 & 174 & 6.4 & 1 \\
\hline
\end{tabular}

Results of the spectrographic analyses indicate detectable concentrations of aluminum, barium, boron, chromium, copper, lead, lithium, molybdenum, nickel, rubidium, strontium, titanium, and vanadium in the basin's streams. In addition, detectable amounts of silver were observed at the following stream-sampling sites:

Location (fig. 1)
Passaic River near Chatham (site 3) .......

Silver (Ag) $(\mu g / l)$

Rockaway River above reservoir, at Boonton (site 8).

0.31

Whippany River at Morristown (site 11)

$0.1-0.2$

Ramapo River near Mahwah (site 27)

Pompton River at Pompton Plains (site 29)

Although sought, concentrations of cobalt, bismuth, beryllium, cadmium, germanium, tin, and zinc were mostly below analytical sensitivity. Two elements, iron and manganese, which are normally included in a listing of trace elements, were in concentrations that 


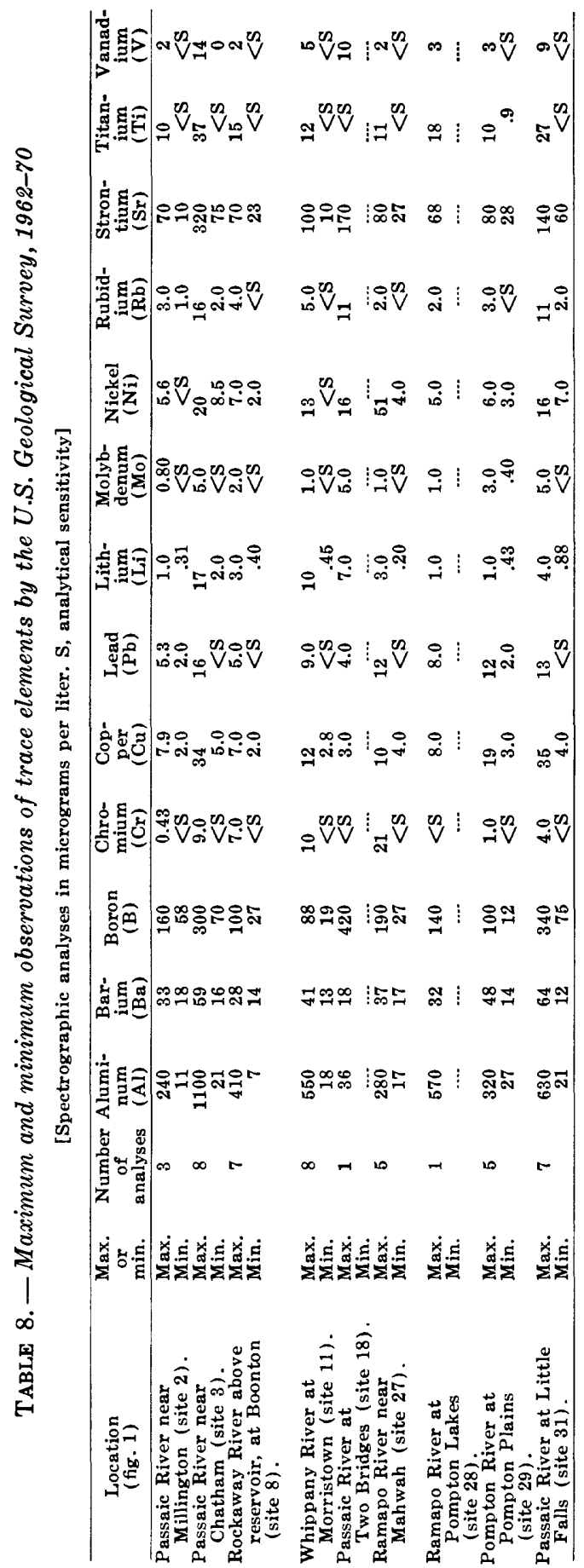


allowed normal methods of analysis. Maximum and minimum observed concentrations of iron are included in table 7. A review of data collected within this basin and data collected in other parts of the State (Anderson, 1970) indicates the prevalence of higher concentrations of trace elements within the Passaic River basin than normally found in other New Jersey streams. This may be related to man's activities, primarily the discharge of industrial and municipal waste waters to the streams.

Because streams in the basin are receiving and transporting increasing amounts of domestic and industrial waste waters, three additional chemical-quality parameters were determined for selected stream samples. These three parameters-orthophosphate, methylene blue active substances (detergents), and phenolic materials-are not normally found in unpolluted waters, or they are found only in minor quantities. They can, therefore, be used as indicators of waste-water discharges. Maximum and minimum concentrations of these parameters are given in table 9. A review

TABLE 9. - Maximum and minimum observations of phosphate, detergent (MBAS), and phenolic-material content by the U.S. Geological Survey, 1962-70

[Chemical analyses of phenolic materials in micrograms per liter; others in milligrams per liter]

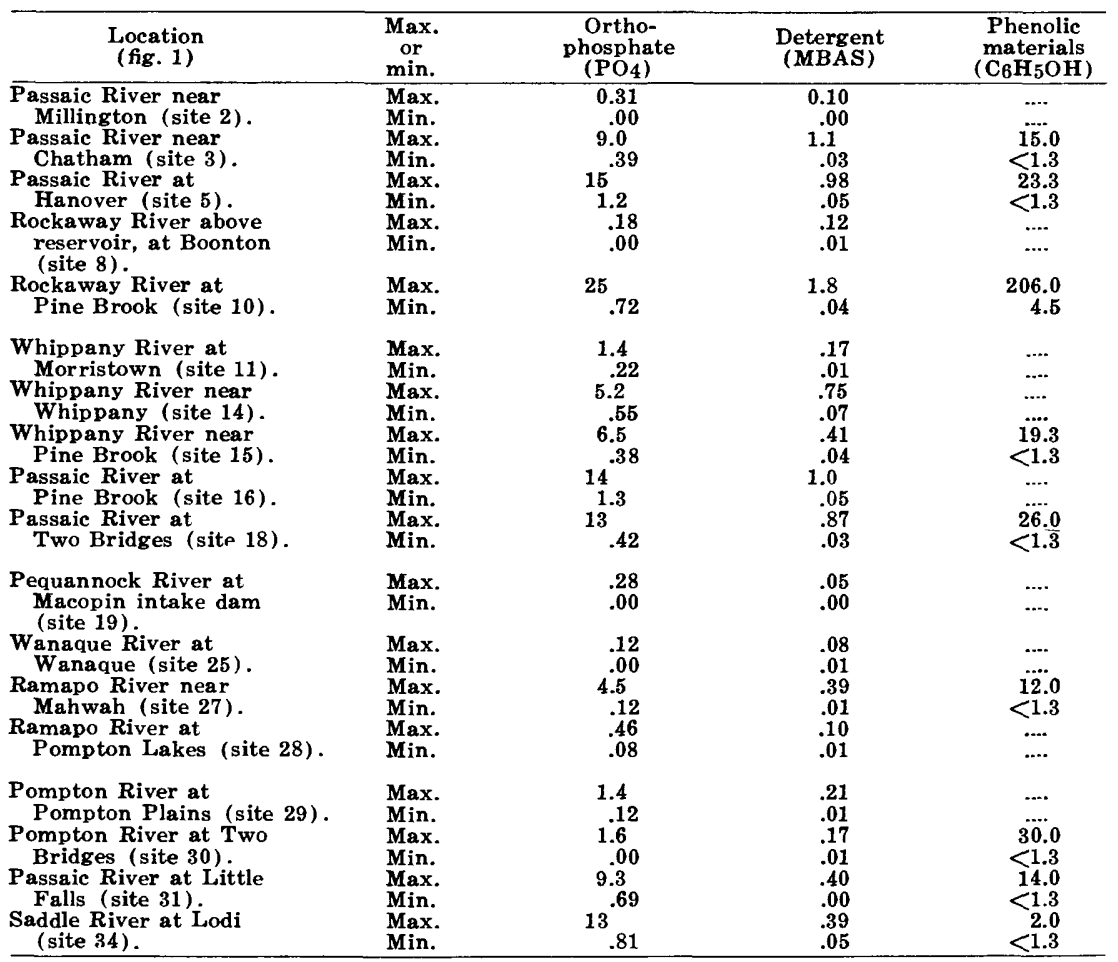


of the data indicates that phenolic materials are present in much higher concentrations than are normally found in unpolluted stream waters in the State (Faust and others, 1971). Similar observations can be made regarding the other two parameters. Interestingly, the concentrations of detergents have lessened since 1966 , probably because of the advent of biodegradable compounds used for cleaning.

\section{TIME VARIATIONS}

Long-term trends of water-quality parameters have seldom been analyzed and reported in the literature, probably because of the relative unavailability of reliable and extensive records of sufficient length to make such an analysis significant. The Passaic River basin affords a unique opportunity for a trend study, because monthly water-quality data from more than 15 sampling sites (table 3) are available from the Passaic Valley Water Commission for the 26-year period 1945-70. Daily determinations of dissolved oxygen and stream temperature are available for both of the Two Bridges sampling sites (fig. 1, sites 18 and 30 ). In addition to these two parameters, daily determinations of coliform bacteria, biochemical oxygen demand, $\mathrm{pH}$, alkalinity, color, and turbidity are available for Little Falls (site 31). Mathematical and graphical models, of course, can be developed from such long-term data. Such models, in turn, can provide bases for predictions of future stream quality and for effective water-quality management in the river system.

In general, three techniques were used in the analyses of longterm water-quality trends in the basin: 12-month moving averages, linear regressions, and double-mass curves. The technique used in developing moving averages was described in the section "Streamflow."

Long-term trends in the concentrations of several parametersdissolved solids, hardness, chloride, sulfate, nitrate, and ammonia -in the Passaic River at Little Falls are shown in figure 13 as a 12-month moving average of composite monthly determinations. Note the inverse relation between the concentrations of these parameters and the values of water discharge (fig. 6). Periods of high flow, such as in 1951-53, are concurrent with decreasing or low concentrations. Likewise, periods of low flow, such as during the 1961-66 drought, produced high concentrations. Although a definite upward long-term trend is apparent in figure 13 (dashed line on dissolved-solids curve), the apparent trend may be related to the general decreasing streamflow (fig. 6).

Water-quality parameters can be expressed in load units. A convenient unit is tons per day, which is derived from the following 


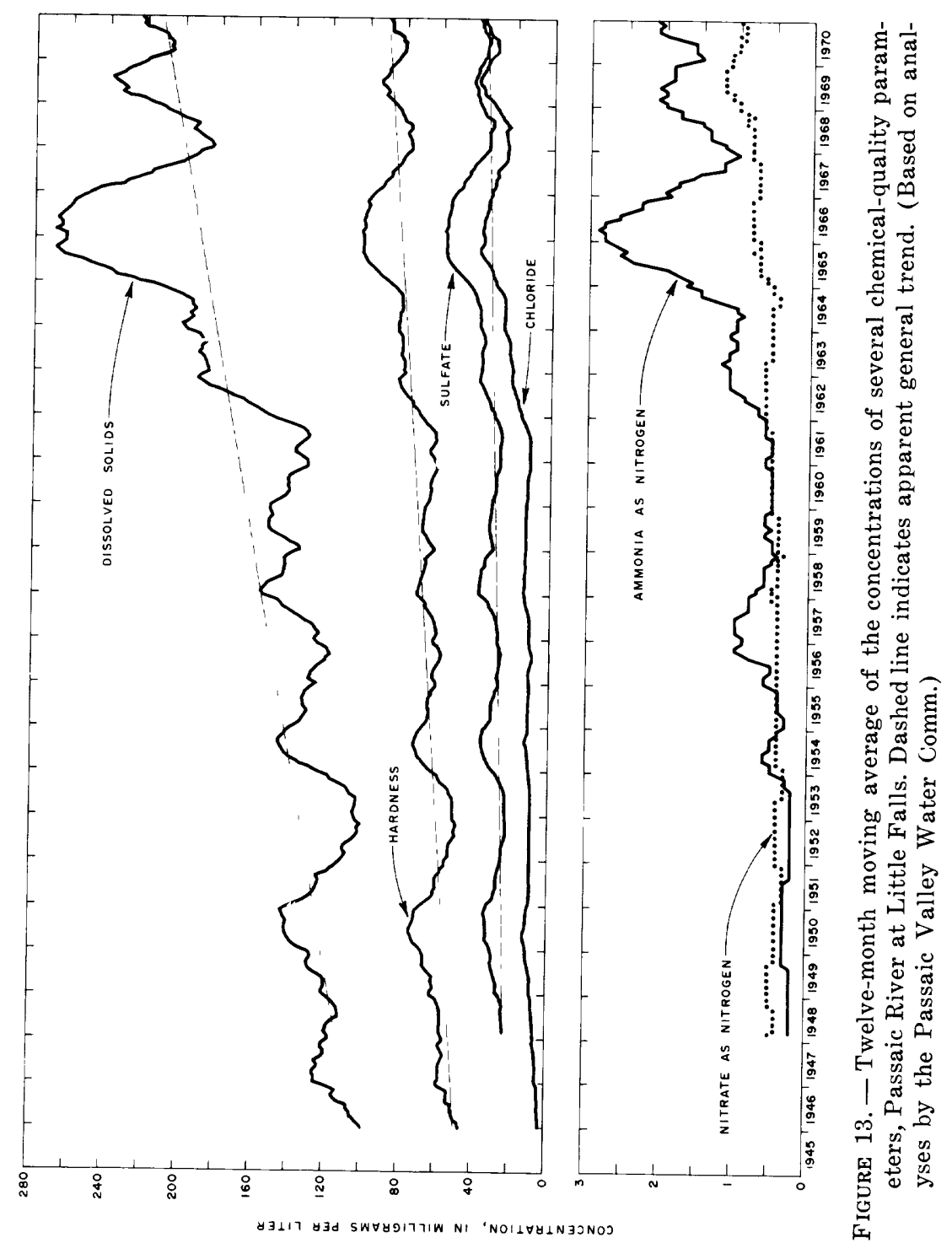


relation between concentration and water discharge:

$$
L=\mathrm{k} C Q \text {, }
$$

where $L$ is load, in tons per day ; $C$ is concentration, in milligrams per liter; and $Q$ is water discharge, in cubic feet per second. The conversion factor $(\mathrm{k})$ is equal to 0.0027 tons per day per $\mathrm{mg} / \mathrm{l}$-cfs.

A second graphical analysis of these quality parameters, showing load rather than concentration units, is shown in figure 14. It illustrates the average load of dissolved material accumulated in the Passaic River system and carried past the Little Falls sampling station.

In an earlier, similar comparison of 24-month moving averages, we $(1965$, p. D216) demonstrated that the dissolved-solids load varied proportionately with streamflow before 1955 , as was expected. However, we noted a divergence in the plots of these two parameters subsequent to 1955 and postulated that, even though the values for load were computed from water discharge, the concentration of dissolved materials increased so markedly with time that the curves diverged. This postulation suggested an increase in dissolved solids per unit volume of water. This observation was tested by linear-regression analyses.

Linear-regression analysis (Steel and Torrie, 1960, p. 161-193) considers the frequency distribution of one variable, the dependent, when another variable, the independent, is held constant. This analysis usually leads to a linear relation between the two variables, described by the general equation:

$$
\bar{Y}_{x}=\bar{Y}+b(X-\bar{X}),
$$

where $\bar{Y}_{x}$ is an estimate of the mean value of the dependent variable for any given value of $X ; \bar{Y}$ is the mean value of the dependent variable; $b$ is the slope of the regression line; and $\bar{X}$ is the mean value of the independent variable. The objective is to derive a linear-regression equation and to solve for $\bar{Y}_{x}$ at various levels of $X$.

In addition, a student's $t$ distribution test for independence of the dependent and independent variables is applied at the 95-percent level of significance. This indicates whether the variance about the mean value of the dependent is influenced by the independent variable for 95 percent of the observations. Thus, an equation of predictive value can be derived.

A linear-regression analysis does not explain or estimate the interaction-cause and effect-between independent and dependent variables. There is, however, a high degree of probability that 


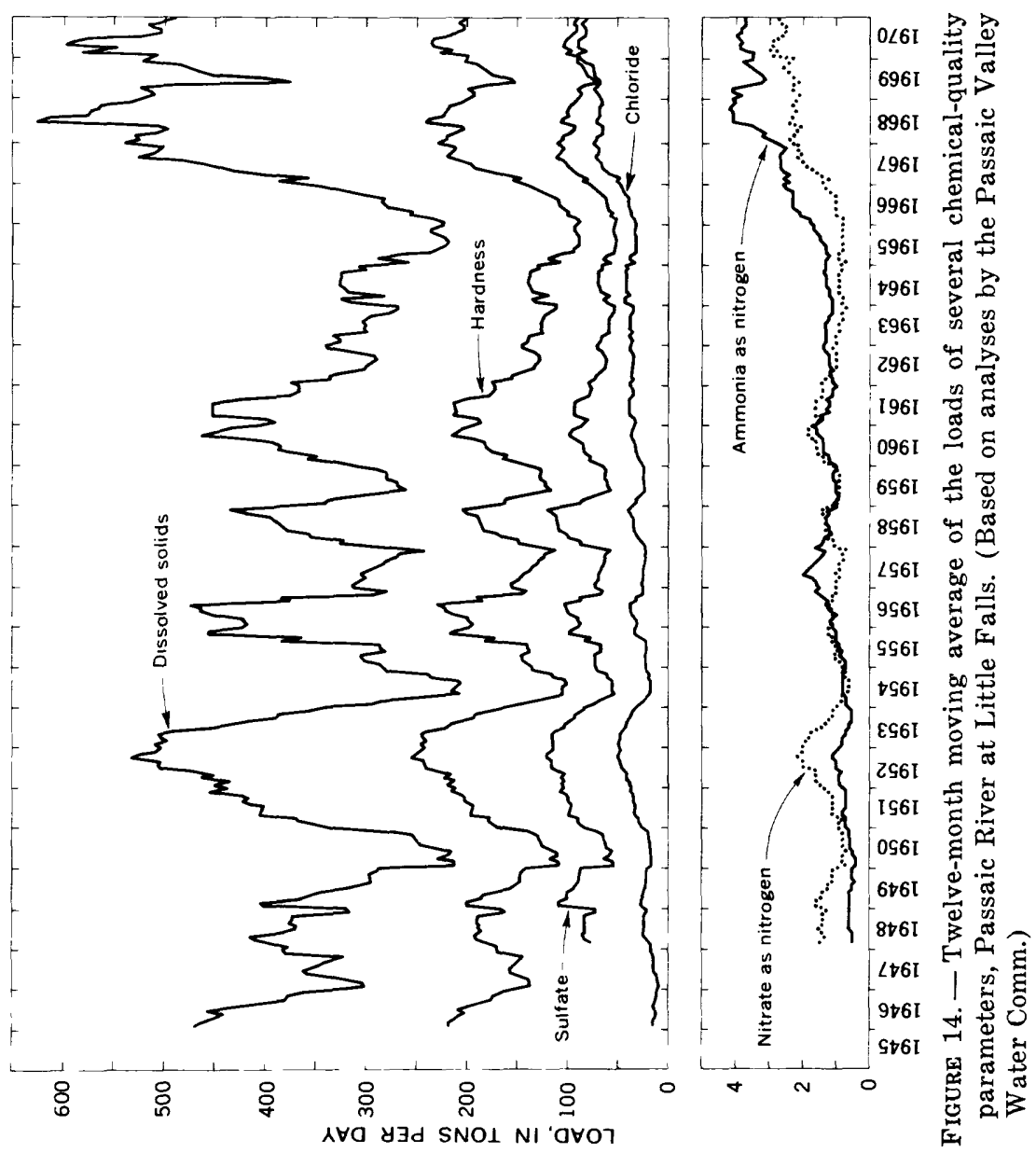


certain elements causing variance in $Y$ also are present in the variance in $X$. Thus, a correlation coefficient, $r_{x y}$, can be calculated for $Y$ upon $X$ (Steel and Torrie, 1960, p. 183-188). The correlation coefficient can vary from -1.0 to +1.0 and measures the proportion of the variance in $Y$ that is associated with another variable, $X$. For example, a coefficient of \pm 0.9 suggests a high degree of correlation between the variance in $Y$ estimated from the linearregression equation and the variance in the actual values of $Y$. There is, therefore, a high degree of probability that the chosen $X$ variable is influencing the variance in $Y$. On the other hand, a coefficient of \pm 0.1 suggests a poor correlation-that is, variables other than the first choice of $X$ are influencing the variance in $Y$.

Another useful statistical test is the coefficient of determination, $r_{x y}^{2}$ (Steel and Torrie, 1960, p. 187). This gives the percentage of variance of $Y$ that is influenced by $X$. In some respects this is more useful than the correlation coefficient in that it gives the percentage of the elements in $Y$ that also are present in $X$. For example, $r^{2}=(+0.90)^{2}$, or 81.0 percent of accountable elements, may be compared to $r^{2}=(+0.10)^{2}$, or 1.0 percent, in the aforementioned example.

Changes in the relation between dissolved-solids content and streamflow at Little Falls are demonstrated by the analysis of mean monthly data collected during 1945-70 (fig. 15). The curves indicate that the dissolved-solids content of the water increased during the period. For example, at a flow of $500 \mathrm{cfs}$, the river carried $130 \mathrm{mg} / \mathrm{l}$ (176 tons per day) dissolved solids in 1947-48, $132 \mathrm{mg} / \mathrm{l}$ (178 tons per day) in 1955-56, $200 \mathrm{mg} / \mathrm{l}$ (270 tons per day) in 1963-64, and $224 \mathrm{mg} / 1$ (302 tons per day) in 1967-68. This comparison cancels the influences of lower streamflows caused by increases in water diversions or by drought in that the plots permit comparison at any selected flow condition. Values of the terms used to define the linear relation for each biannual period are tabulated below. A trial and error analysis established a linear relation when streamflow was expressed in the logarithmic form. Time was introduced as a nonmathematical variable by grouping the monthly mean data into biannual sequences.

A Student's $t$ distribution test for independence of the dissolved solids $(Y)$ and water discharge $(X)$ was applied at the 95-percent level of significance for the entire period. It indicated that the variance about the value of dissolved solids was not influenced by water discharge for 95 percent of the observations. Evidently, some other variable, such as waste-water discharge, is responsible for the increase in variance around a mean dissolved-solids content per unit volume of discharge during 1945-70. 


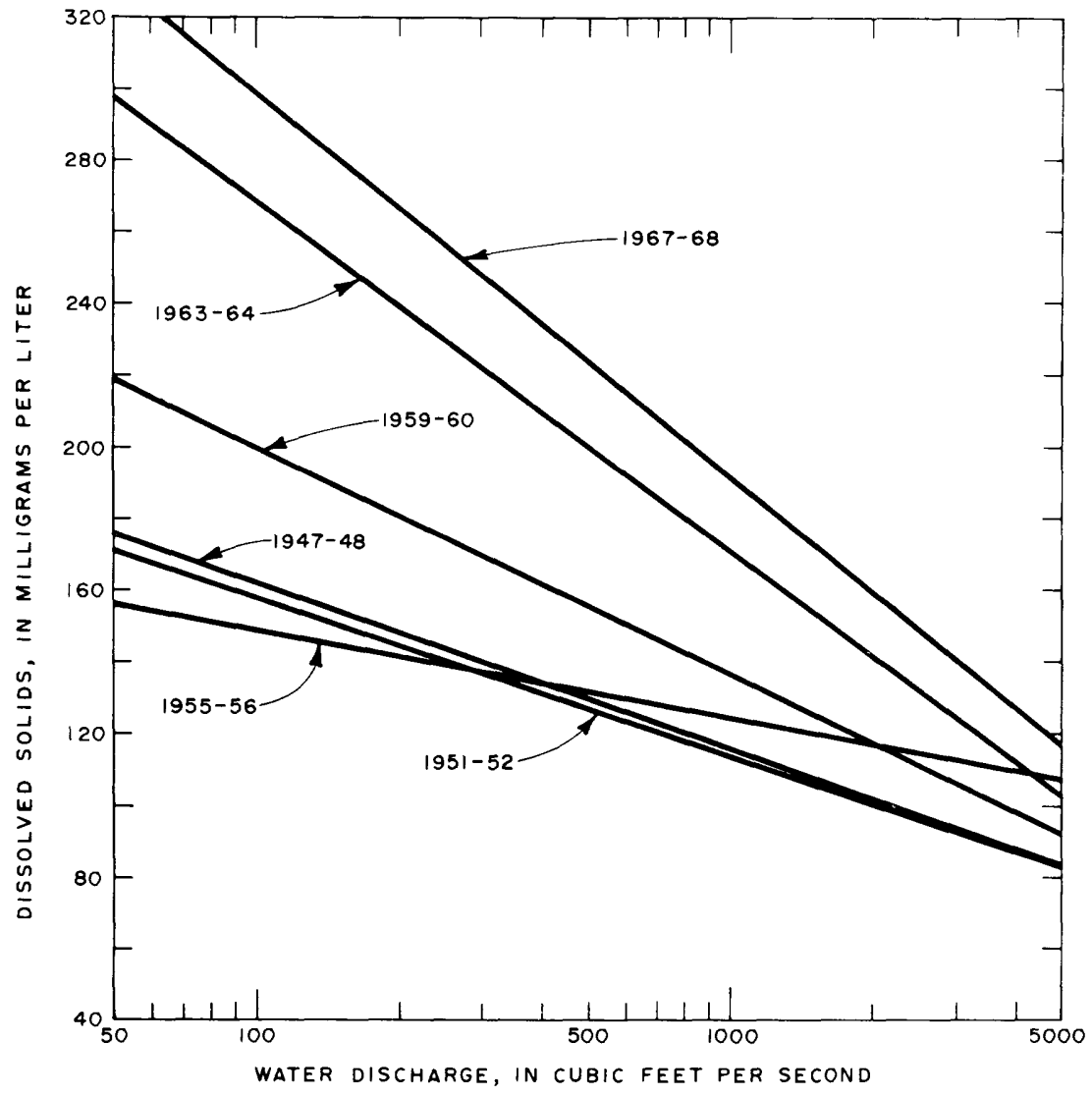

Figure 15. - Relation between water discharge and dissolved solids, Passaic River at Little Falls, derived by linear-regression analysis. (Based on analyses by the Passaic Valley Water Comm.)

Linear-regression parameters for the relation between dissolved solids and streamflow

\begin{tabular}{|c|c|c|c|c|}
\hline Period & $\begin{array}{l}\text { Mean } \\
\text { dissolved } \\
\text { solids } \\
(\bar{Y})\end{array}$ & $\begin{array}{c}\text { Slope } \\
(b)\end{array}$ & $\begin{array}{l}\text { Log of mean } \\
\text { streamflow } \\
(\log \bar{X})\end{array}$ & $\begin{array}{l}\text { Cofficient } \\
\text { of deter- } \\
\text { mination } \\
\left(r^{2}\right)\end{array}$ \\
\hline 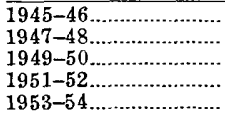 & $\begin{array}{l}112.0 \\
118.8 \\
134.3 \\
108.0 \\
131.4\end{array}$ & $\begin{array}{l}-63.7 \\
-46.1 \\
-37.5 \\
-44.3 \\
-47.8\end{array}$ & $\begin{array}{l}3.066 \\
2.939 \\
2.787 \\
3.146 \\
2.806\end{array}$ & $\begin{array}{r}0.4749 \\
.5424 \\
.3533 \\
.4544 \\
.5199\end{array}$ \\
\hline $\begin{array}{l}1955-56 \ldots \ldots \\
1957-58 \ldots \ldots \ldots \ldots \\
1959-60 \ldots \ldots \ldots \ldots \ldots \ldots \ldots \\
1961-62 \ldots \ldots \ldots \ldots \ldots \ldots \ldots \ldots\end{array}$ & $\begin{array}{l}126.3 \\
144.8 \\
141.3 \\
168.5\end{array}$ & $\begin{array}{l}-24.6 \\
-62.0 \\
-63.3 \\
-84.9\end{array}$ & $\begin{array}{l}2.916 \\
2.797 \\
2.924 \\
2.799\end{array}$ & $\begin{array}{l}.1215 \\
.5494 \\
.5153 \\
.5783\end{array}$ \\
\hline $\begin{array}{l}1963-64 \ldots \ldots \ldots \\
1965-66 \ldots \ldots \ldots \ldots \\
1967-68 \ldots \ldots \ldots \ldots \ldots \ldots \ldots \ldots \\
1969-70 \ldots \ldots \ldots \ldots \ldots \ldots \ldots\end{array}$ & $\begin{array}{l}210.8 \\
256.0 \\
200.7 \\
221.3\end{array}$ & $\begin{array}{r}-98.6 \\
-76.4 \\
-108.1 \\
-115.7\end{array}$ & $\begin{array}{l}2.599 \\
2.545 \\
2.926 \\
2.863\end{array}$ & $\begin{array}{l}.4436 \\
.2881 \\
.7472 \\
.7706 \\
\end{array}$ \\
\hline
\end{tabular}


Information on the dissolved-solids content at sampling sites above Little Falls was not available from the commission's files. Thus, measurements of the chloride content, which were available, were selected as an indicator of the long-term trends in chemical quality. Again, the 12-month moving-average technique was utilyzed to establish the trends (fig. 16).

The Passaic River system above the confluence with the Rockaway-Whippany River system is represented by the Millington (fig. 1, site 2), Chatham (site 3), and Hanover Neck (site 6) sampling sites. A slight upward trend in chloride content around a mean of $13 \mathrm{mg} / \mathrm{l}$ is apparent for the Millington site during the 10-year period 1961-70. Because of the shorter time period in which data were collected at Chatham, no clear trend is apparent. However, a comparison of this plot with plots of data collected at Hanover Neck and at Millington indicates that a large source of chloride is located between the Millington and Chatham sites. The

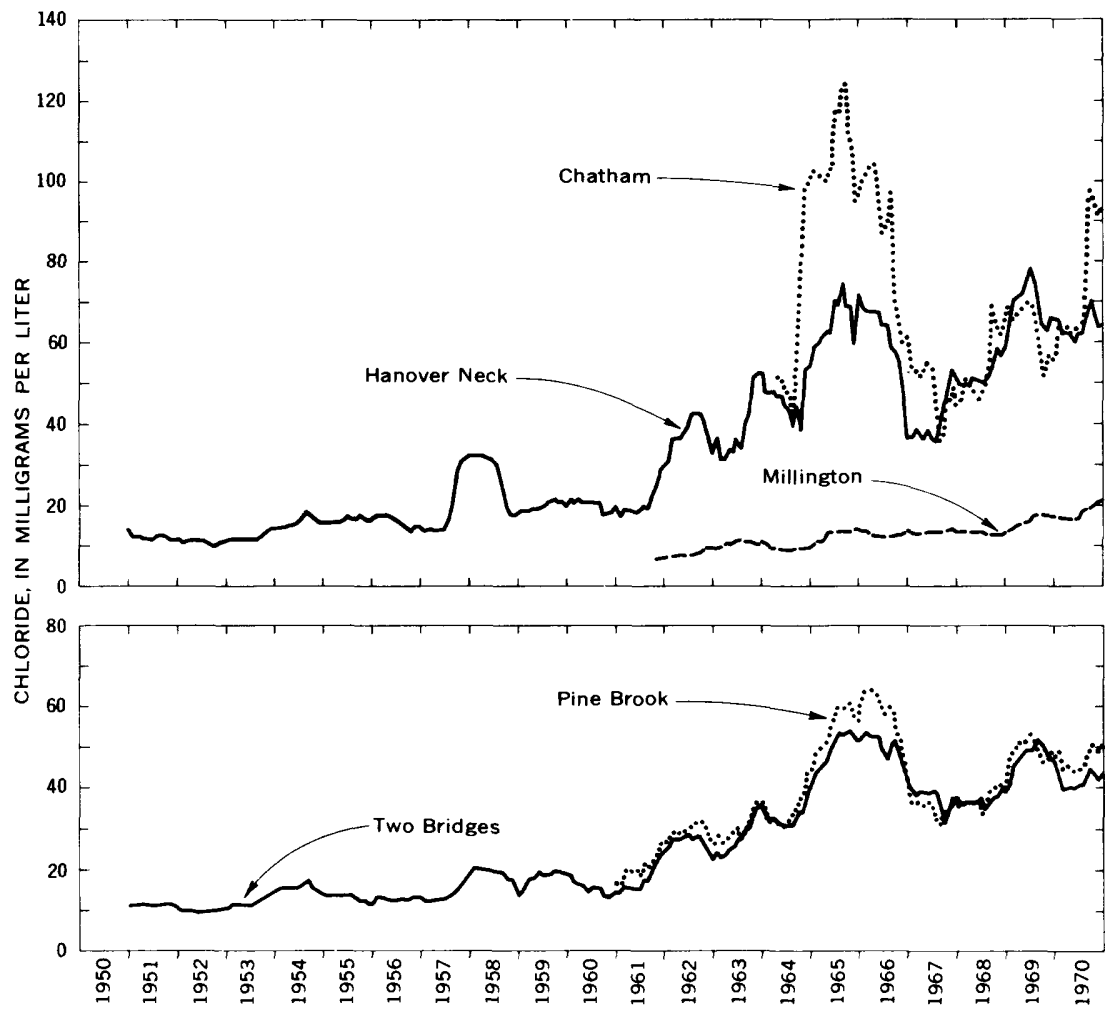

Figure 16. - Twelve-month moving average of chloride at selected sampling sites. (Based on analyses by the Passaic Valley Water Comm.) 
source of the chloride ions was traced by the State Department of Environmental Protection to a chemical industry. This industry is currently (1972) investigating alternate methods of disposal for this particular waste. Data collected at the Hanover Neck site (1950-70) indicate a definite upward trend around a mean of $34 \mathrm{mg} / \mathrm{l}$. Note the considerable increase in chloride content at this sampling site during the drought years (1961-66), with a maximum 12-month moving average of $75 \mathrm{mg} / \mathrm{l}$ observed in 1965 (similar peak at Chatham was $124 \mathrm{mg} / \mathrm{l}$ ), and during the later years $1968-70$.

Upward trends were observed also at Pine Brook (site 16) and Two Bridges (site 18) on the Passaic River, both below the confluence with the Rockaway-Whippany River system. However, chloride content at Pine Brook and at Two Bridges is lower than that noted at Hanover Neck and at Chatham and reflects the dilution mainly contributed by the Rockaway-Whippany River system inflow. Similarly, inflow of the Pompton River system below the Two Bridges sampling site lowers the chloride content at Little Falls (fig. 13).

Similar plots of chloride content were prepared for the most downstream sampling sites on the Whippany, Rockaway, and Pompton Rivers. All showed a general upward trend, with a peak observed in 1965. Data from the Whippany River near Pine Brook (1950-70) revealed an upward trend around a mean value of $22 \mathrm{mg} / 1$; from the Rockaway River at Pine Brook (1948-70), around a mean value of $20 \mathrm{mg} / \mathrm{l}$; and from the Pompton River at Two Bridges (1950-70), around a mean value of $12 \mathrm{mg} / \mathrm{l}$.

\section{BIOCHEMICAL CHARACTERISTICS}

Organic materials usually are decomposed by microorganisms in the presence of DO (dissolved oxygen); thus, oxygen is an essential ingredient in the natural purification of streams receiving waste-water discharges. The rate of biochemical decomposition is dependent on water temperature; that is, the warmer the water, the faster the rate of decomposition. Also, the solubility of oxygen at saturation is related inversely to water temperature. When the rate of oxygen consumption exceeds the rate at which the stream is replenished by oxygen, the water eventually becomes undersaturated. Thus, the degree or percentage of undersaturation often is used as an indicator of the amount of organic pollution carried by a stream.

The ultimate decomposition products of organic waste materials are carbon dioxide, ammonia, nitrite, nitrate, hydrogen sulfide, and sulfate; the exact form of nitrogen and sulfur is dependent 
on whether the system is aerobic or anaerobic. Thus, these decomposition products also can be used as pollution indicators, if naturally occurring concentrations do not mask their presence.

Two other indicators of pollution are BOD (biochemical oxygen demand) and the coliform group of bacteria. BOD, an indirect measure of the organic-matter content, is the amount of oxygen used under standardized conditions of temperature and incubation period-usually 5 days at $20^{\circ} \mathrm{C}$-by microorganisms in the oxidation of the organic matter and is reported as equivalents of DO. The coliform group of bacteria, although not normally pathogenic, is used to indicate conditions and sources of pollution in a stream. These bacteria are common to the waste products of animals and man and, thus, are found in domestic sewage and in some agricultural waste waters. They normally are not found in industrial waste water.

\section{DISSOLVED OXYGEN AND BIOCHEMICAL OXYGEN DEMAND}

Long-term trends in DO and BOD at Little Falls are shown in figure 17. Both parameters are expressed as concentration (milligrams per liter) and load (tons per day). DO is expressed also as percentage of saturation, to nullify the effects of stream temperature. However, comparison of the concentration and saturation curves shows roughly parallel patterns.

The curve representing percentage of oxygen saturation illustrates that the river water consistently was undersaturated at the sampling site during the entire period of observation, 1945-70. The general trend (dashed line) indicates that oxygen saturation decreased about 20 percent during the period, or about 0.8 percent per year. The 10-15 percent decrease in oxygen saturation during 1958-61 probably resulted from a substantial increase in production and associated waste-water discharge by a paper industry on one of the upstream tributaries. The recovery noted in 1961 probably resulted from the installation of more efficient waste-treatment facilities by this industry. The increase in DO of about 5 percent during the early 1950 's is related to higher streamflows during this period (fig. 6).

BOD is plotted also in figure 17. An upward trend with time is apparent when BOD is expressed in concentration units.

DO and BOD loads are depicted in the lower part of figure 17. DO shows a slight downward trend with time. This DO is the oxygen load remaining in the river after part of the BOD is satisfied and, thus, reflects the undersaturation illustrated in the upper graph. The downward trend can be attributed to two factors: (1) decreased streamflows during the period shown, which, according to Churchill and others (1962), can decrease oxygen content 
NOII

JPHINJJYGA NI 'NJTAXO 0JATOSSIO @

8 \& \& \&
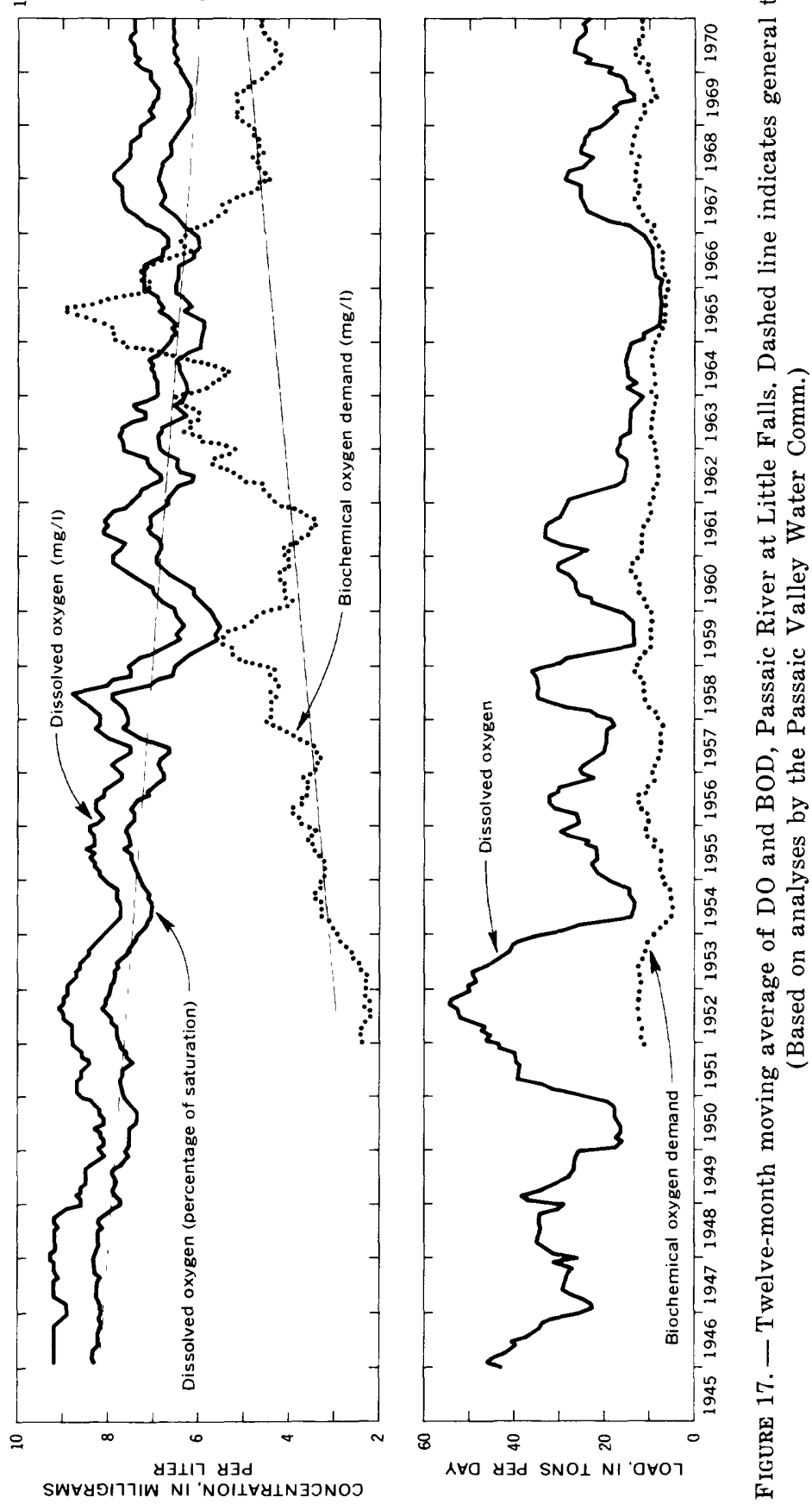

¿্் 
because of reduced turbulence, and (2) increased quantities of waste water discharged into the river system. However, the 12-month moving-average analysis of BOD load did not reveal any definite upward or downward trend. Note, however, that the increase in the concentration of BOD (upper graph) and the concurrent decrease in streamflow (fig. 6) combine to produce this relatively constant residual BOD load (lower graph).

The DO- and BOD-load curves generally tend to converge. This suggests that, even with a higher percentage of. waste treatment in the basin during recent years, greater demands are being placed on the natural assimilation capacity of the river system. Two periods of pronounced convergence, 1953-56 and 1964-67, can be explained by the influence of streamflow on DO load; that is, the lower the streamflow, the lower the oxygen load.

We noted above that the BOD load at Little Falls was relatively stable during the period under study. But was it? Was the increase in waste-water discharge masked by low flow due to drought? This hypothesis was tested with linear-regression analyses.

Examples of the linear-regression plots are shown in figure 18. An increase in the concentration of BOD with time is obvious, especially at lower streamflows. The statistics needed to formulate the linear-regression equations are given in the table below.

Linear-regression parameters for the relation between $B O D$ and streamflow

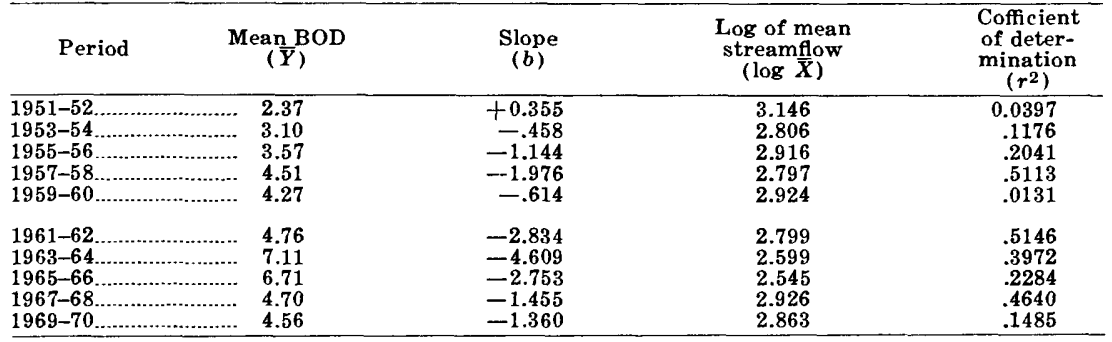

The effect of dilution also is apparent, but the decrease in concentration is not proportional to the dilution factor. Consider, for example, the 1963-64 data (fig. 18). They indicate a BOD of $6.7 \mathrm{mg} / \mathrm{l}$ at a flow of $500 \mathrm{cfs}$ and $3.1 \mathrm{mg} / \mathrm{l}$ at a flow of $3,000 \mathrm{cfs}$. A 1:6 dilution model would predict a concentration of $1.1 \mathrm{mg} / \mathrm{l}$ at the higher flow rate. This observation suggests an increase in the input of oxygen-demanding materials at higher streamflow, perhaps by the resuspension of previously deposited organic matter, as well as by the washing of additional biodegradable materials into the river system during storm runoff. This latter effect might be expected to be greater in widely separated storms than 


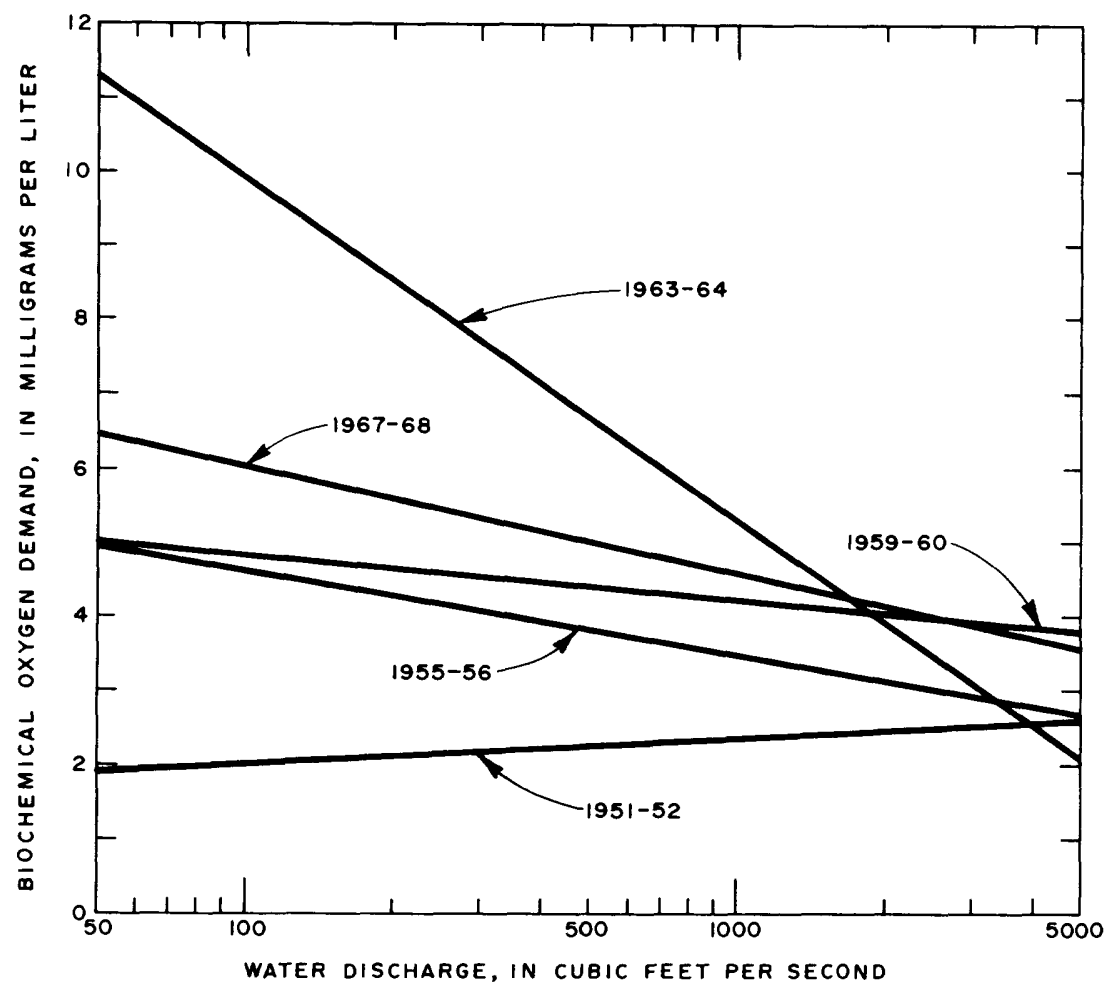

FIGURE 18. - Relation between water discharge and BOD, Passaic River at Little Falls, derived by linear-regression analysis. (Based on analyses by the Passaic Valley Water Comm.)

in the second or third storm in close succession. Another possible explanation for higher BOD with higher flows is related to the source of waste-water discharge in relation to the sampling site and the traveltime between the two sites. Increasing flows decrease traveltimes and thus lessen the time available for biological decomposition. This, in effect, increases the measured BOD at the sampling site. Conversely, low flows increase traveltimes and allow biochemical actions to reduce the BOD measured at the sampling site.

A dilution effect on the BOD is suggested by the negative slopes ( $b$ values). The decrease in concentration, however, is not in accord with the dilution factor. Moreover, Student's $t$ tests at the 95-percent level of significance revealed that this inverse relation was valid only in the $1955-56,1957-58,1961-62,1963-64,1965-66$, 1967-68, and 1969-70 groups. The $b$ values in other biannual groups were not significantly different from zero-that is, no slope. 
Computations of coefficients of correlation and determination suggest little correlation between BOD concentrations and streamflow.

In the above analyses, the data were grouped biannually where the primary purpose was to determine a time trend toward an increase or decrease in oxygen demand. Such an approach ignores the eflect of seasonal variations of temperature upon the rate of decomposition of organic matter and upon the solubility of oxygen in water. Consequently, the data were regrouped so that water temperature would be very nearly equal within a specific period. A quarterly grouping on a calendar basis was found quite appropriate.

The statistics needed to formulate the quarterly linear-regression equations for concentration versus the logarithim of streamflow are given in the table below.

Linear-regression parameters for the relation between $B O D$ and streamflow

\begin{tabular}{|c|c|c|c|c|}
\hline $\begin{array}{c}\text { Quarter } \\
(1951-70)\end{array}$ & $\underset{(\bar{Y})}{\operatorname{Mean} \mathrm{BOD}}$ & $\begin{array}{l}\text { Slope } \\
(b)\end{array}$ & $\begin{array}{l}\text { Log of mean } \\
\text { streamflow } \\
\quad(\log \bar{X})\end{array}$ & $\begin{array}{c}\text { Coefficient } \\
\text { of deter- } \\
\text { mination } \\
\left(r^{2}\right)\end{array}$ \\
\hline 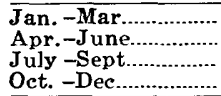 & $\begin{array}{ll}. . & 4.85 \\
\cdots & 3.92 \\
- & 4.77 \\
. . & 4.72\end{array}$ & $\begin{array}{l}-4.205 \\
-3.215 \\
-4.020 \\
-3.284\end{array}$ & $\begin{array}{l}3.084 \\
2.935 \\
2.521 \\
2.789\end{array}$ & $\begin{array}{l}0.5033 \\
.5811 \\
.3155 \\
.3210\end{array}$ \\
\hline
\end{tabular}

All quarters exhibit the inverse relation that was noted in the analysis of biannual data. Student's $t$ tests indicated that all slopes are significantly different from zero at the 95-percent confidence level. The coefficients of correlation and determination are considerably higher than those obtained from the biannual data. This can be attributed to the regrouping of the data around more uniform temperature conditions.

Regression analyses of the quarterly data are shown in figure 19. The first quarter (Jan. to Mar.) produced the highest estimates of BOD, and the third quarter (July to Sept.), the lowest. The second and fourth quarters are very nearly the same, as seen by the slopes of -3.22 and -3.28 , respectively. This is in accord with expectations, because warmer stream temperatures during April through September bring increased bacterial activity and higher decomposition rates of organic matter.

The regression analyses of BOD (fig. 18) suggest an increase with time in the concentration of decomposable organic materials in the river system above Little Falls per unit of streamflow. If true, a greater demand on the river's oxygen content also should be observed. Consequently, regression analyses were made using DO as the dependent variable and streamflow as the independent variable. 


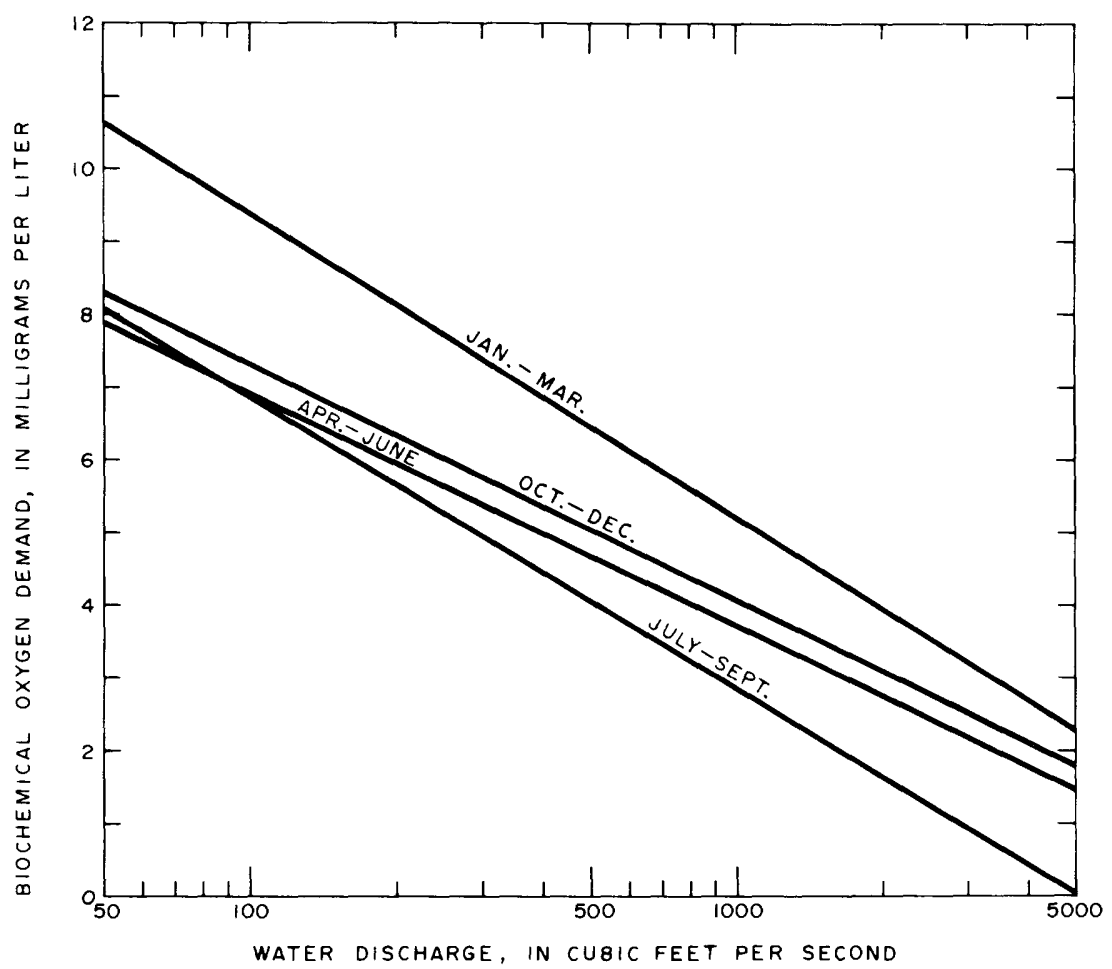

FIGURE 19. - Seasonal relation between water discharge and BOD, Passaic River at Little Falls, derived by linear-regression analysis for the period 1951-70. (Based on analyses by the Passaic Valley Water Comm.)

Examples of the regression analyses of biannually grouped data on the concentration of DO are shown in figure 20. There seems to be little or no significant decrease or increase in oxygen concentration for a given flow during 1951-70 despite a concurrent increase in the concentration of oxygen-demanding materials (fig. 18). There is, however, a tendency for the oxygen content to increase with increase in flow; the slopes are positive. As noted earlier, increased turbulence at these higher discharge rates may produce an increase in DO. Statistics used in defining the illustrated examples and other biannual groupings are given in the table below. Note that mean values of both DO and flow have a slight tendency to decrease with time.

In order to perceive some indication of the influence of water temperature on DO levels, these data were grouped by calendar quarters, as was done with the BOD data. Plots of the linearregression lines obtained by the analysis of concentration are presented in figure 21. Lowest concentrations were observed during 


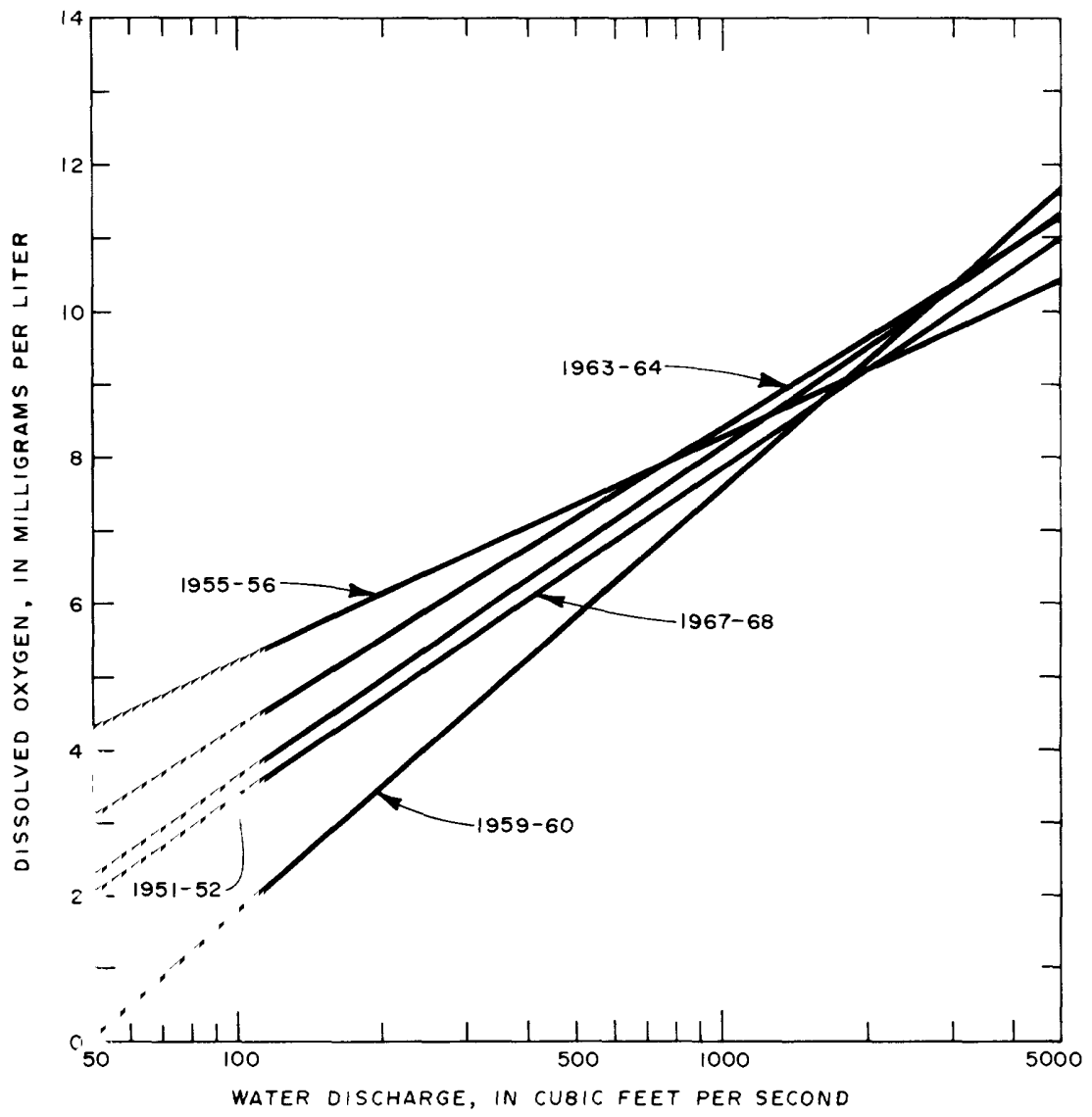

FIgURE 20. - Relation between water discharge and DO, Passaic River at Little Falls, derived by linear-regression analysis. (Based on analyses by the Passaic Valley Water Comm.)

Linear-regression parameters for the relation between DO and streamflow

\begin{tabular}{|c|c|c|c|c|}
\hline Period & $\underset{(\bar{Y})}{\operatorname{Mean}}$ & $\begin{array}{l}\text { Slope } \\
(b)\end{array}$ & $\begin{array}{c}\text { Log of mean } \\
\text { streamflow } \\
\quad(\log \bar{X})\end{array}$ & $\begin{array}{l}\text { Coefficient } \\
\text { of deter- } \\
\text { mination } \\
\left(r^{2}\right)\end{array}$ \\
\hline $\begin{array}{l}1945-46 \\
1947-48 \\
1949-50 \\
1951-52 \\
1953-54\end{array}$ & $\begin{array}{ll}. . & 9.04 \\
. . & 8.96 \\
. . & 8.40 \\
. . & 8.83 \\
. . & 8.09\end{array}$ & $\begin{array}{l}+0.182 \\
+1.811 \\
+4.048 \\
+4.559 \\
+3.738\end{array}$ & $\begin{array}{l}3.066 \\
2.939 \\
2.788 \\
3.146 \\
2.806\end{array}$ & $\begin{array}{l}0.0007 \\
.1181 \\
.5824 \\
.3802 \\
.5596\end{array}$ \\
\hline $\begin{array}{l}1955-56 \ldots \ldots \\
1957-58 \ldots \ldots \ldots \\
1959-60 \ldots \ldots \ldots \\
1961-62 \ldots \ldots \ldots\end{array}$ & $\begin{array}{ll}. & 8.03 \\
. . & 7.87 \\
. & 7.19 \\
. . & 7.59\end{array}$ & $\begin{array}{l}+3.143 \\
+3.660 \\
+5.855 \\
+4.732\end{array}$ & $\begin{array}{l}2.916 \\
2.797 \\
2.924 \\
2.799\end{array}$ & $\begin{array}{l}.1953 \\
.3659 \\
.2993 \\
.5154\end{array}$ \\
\hline $\begin{array}{l}1963-64 \ldots \ldots \ldots \\
1965-66 \\
1967-68 \ldots \ldots \ldots \ldots \ldots \\
1969-70\end{array}$ & 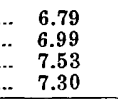 & $\begin{array}{l}+4.113 \\
+3.894 \\
+4.510 \\
+4.646 \\
\end{array}$ & $\begin{array}{l}2.599 \\
2.545 \\
2.926 \\
2.863 \\
\end{array}$ & $\begin{array}{l}.3888 \\
.3255 \\
.2957 \\
.2740 \\
\end{array}$ \\
\hline
\end{tabular}




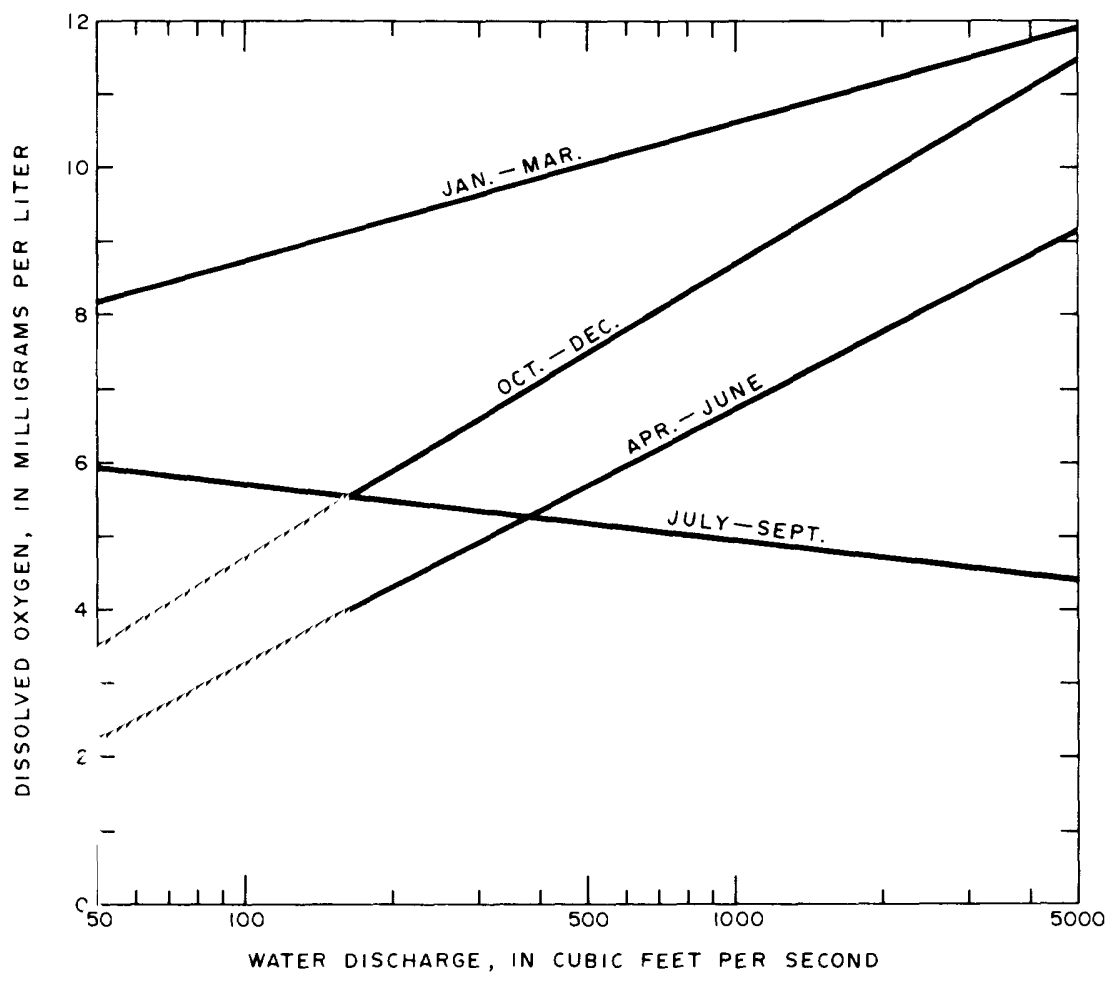

FIGURE 21. - Seasonal relation between water discharge and DO, Passaic River at Little Falls, derived by linear-regression analysis for the period 1951-70. (Based on analyses by the Passaic Valley Water Comm.)

the second and third quarters (Apr. to Sept.), whereas highest values were observed in the first (Jan. to Mar.) and fourth (Oct. to Dec.) quarters. This is in accord with expectations, because warmer temperatures during April through September bring lower DO levels through lower solubilities and higher decomposition rates of organic materials. Statistics used to define these linear relations are given below:

Linear-regression parameters for the relation between $D O$ and streamflow

\begin{tabular}{|c|c|c|c|c|}
\hline $\begin{array}{c}\text { Quarter } \\
(1951-70)\end{array}$ & $\operatorname{Mean}_{(\bar{Y})}$ DO & $\begin{array}{c}\text { Slope } \\
(b)\end{array}$ & $\begin{array}{c}\text { Log of mean } \\
\text { streamflow } \\
(\log \bar{X})\end{array}$ & $\begin{array}{c}\text { Coefficient } \\
\text { of deter- } \\
\text { mination } \\
\left(r^{2}\right)\end{array}$ \\
\hline 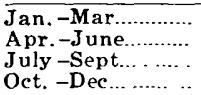 & $\begin{aligned} 10.78 \\
6.53 \\
5.32 \\
7.84\end{aligned}$ & $\begin{array}{r}+1.872 \\
+3.524 \\
+.757 \\
+4.004\end{array}$ & $\begin{array}{l}3.084 \\
2.935 \\
2.521 \\
2.789\end{array}$ & $\begin{array}{r}0.3732 \\
.05209 \\
.0529 \\
.3807\end{array}$ \\
\hline
\end{tabular}

The regression analysis indicates that BOD (fig. 18) increased during 1951-70. On the other hand, the same analysis suggests 
that DO (fig. 20) decreased very slightly, if at all, through the same period. Thus, the capacity of the Passaic River to receive, transport, and assimilate decomposable organic materials apparently has not been exceeded. This statement becomes valid if the data are considered broadly. However, daily records show periods of a month or more when the river's assimilation capacity is exceeded or nearly so, especially during the critical summer quarter, July to September.

To investigate the contention that organic pollution is increasing with time in the Passaic River, a concept of "reserve" DO is introduced here. This concept is simple; the "reserve" DO is merely the arithmetic difference between the DO and the BOD that were estimated by regression analyses. This approach seems valid, because both of these water-quality parameters are expressed in equivalents of DO. In other words, if organic materials increase in a river system, then the "reserve" of oxygen is reduced.

Examples of the curves obtained for the "reserve" DO are

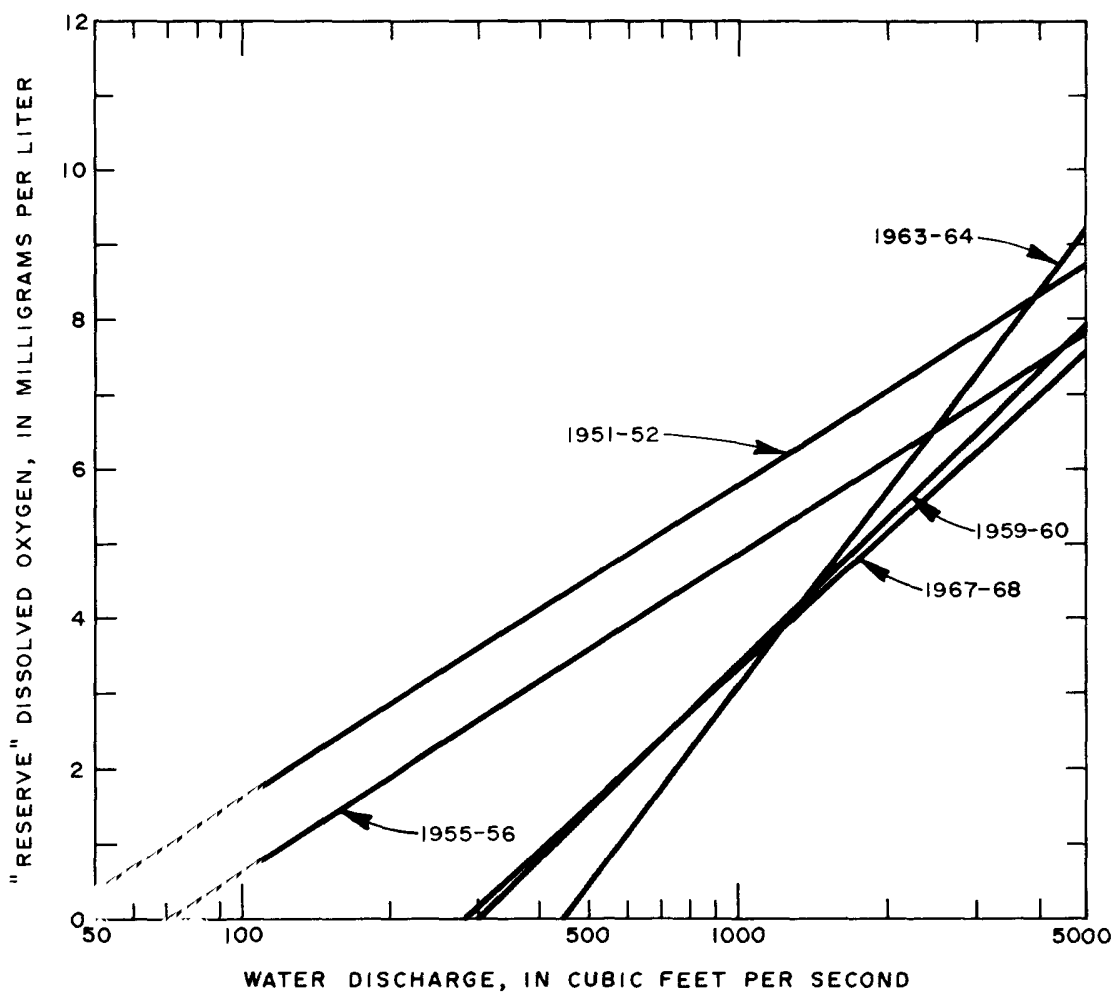

Figure 22. - Relation between water discharge and concentration of "reserve" DO, Passaic River at Little Falls. 
shown for several biannual groups in figure 22. Similar curves for quarterly groups are shown in figure 23. Biannual grouping shows an obvious decrease in "reserve" oxygen levels with time, especially during the more recent years. Quarterly grouping indicates that the second and third quarters (Apr. to Sept.) seem to be the periods in which the "reserves" of oxygen available for the decomposition of additional pollution loadings are reduced most severely, especially at the lower flow rates.

Information on DO and BOD at sampling sites above Little Falls also is available from the commission's files. Twelve-month moving-average analyses of DO, expressed in percentage of saturation, and of BOD, expressed in concentration units, are shown in figures 24 and 25 , respectively.

The Passaic River above the confluence of the Rockaway-Whippany River system is represented by the Millington, Chatham, and Hanover Neck sampling sites. DO (fig. 24) is shown to have been undersaturated during the entire period of observation at these three sites. In addition, an apparent downward trend with time is evident at Millington (fig. 1, site 2) and Hanover Neck (site 6). The period of observation at Chatham (site 3) was too short to indicate any significant trend. Average percentage of DO satura-

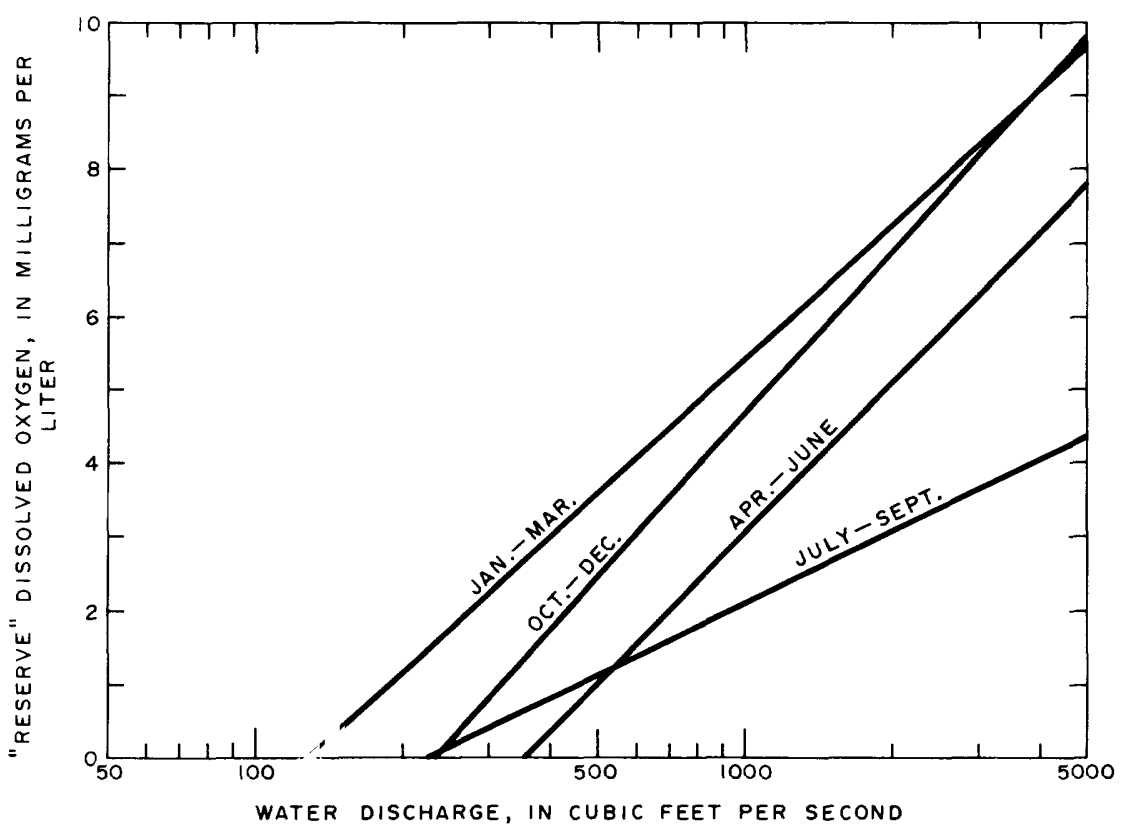

FIGURE 23. - Seasonal relation between water discharge and concentration of "reserve" DO, Passaic River at Little Falls, 1951-70. 


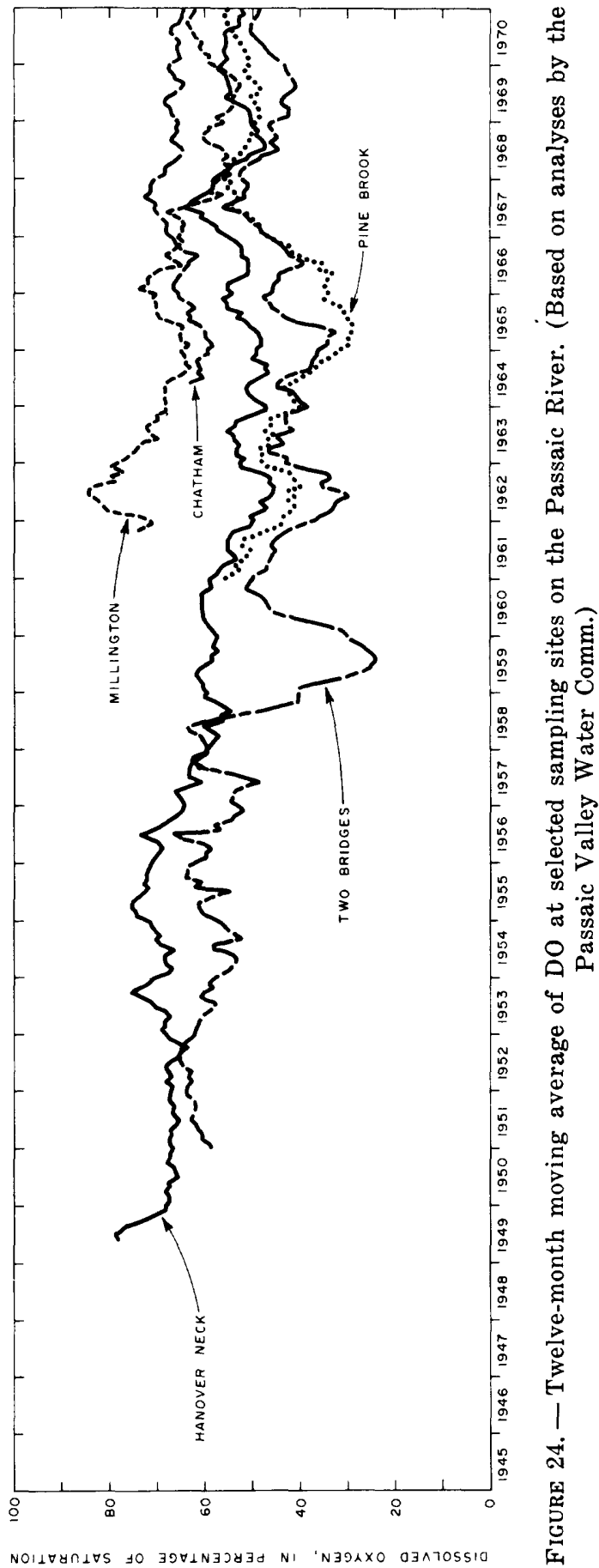


tion for the period of observation was 65 at Millington, 66 at Chatham, and 60 at Hanover Neck.

The Pine Brook (site 16) and Two Bridges (site 18) sampling sites illustrate mainly the combined influence of the RockawayWhippany River system and the upper Passaic River system. Again, DO values at these sites indicate that the river in this reach was undersaturated during the entire period of observation. Compared with the other sampling sites on the Passaic River, this reach had the lowest values, averaging 47 percent at Pine Brook and 49 percent at Two Bridges. An apparent downward trend is observed at Two Bridges, but the period of observation at Pine Brook was too short for a meaningful trend analysis.

Lower percentages of oxygen-saturation values at Pine Brook and Two Bridges are related, of course, to the inflow of highoxygen-demanding water from the Rockaway-Whippany River system. Similar moving-average analyses at sampling sites on the Rockaway and Whippany Rivers near their confluence with the Passaic River indicate that the Rockaway-Whippany system is undersaturated with oxygen. A downward trend is observed on the Rockaway River, and an uneven trend is observed on the Whippany River. An apparent improvement in oxygen levels at the Whippany River station during recent years may be caused by improved treatment facilities at a major upstream source of an industrial waste water. Oxygen saturation levels at the Rockaway River sampling site averaged 60 percent, whereas at the Whippany River site they averaged 47 percent.

The other major tributary system upstream from Little Falls is the Pompton River system. Oxygen levels in the Pompton River above the confluence, although undersaturated during the entire period of record and showing a slight downward trend, averaged 89 percent and rarely dropped below 80 percent. The influence of this inflow on improving the oxygen levels at Little Falls (fig. 17) is evident by comparison of the curve at Little Falls (mean 71 percent) with that at Two Bridges (mean 49 percent). Also, a recovery at Little Falls is caused by less utilization or oxygen demand than that at Two Bridges.

Twelve-month moving averages of BOD are shown in figure 25 . Long-term data (greater than $10 \mathrm{yr}$ of record) in the upper Passaic River system, above the Rockaway-Whippany Rivers confluence, are available only at Hanover Neck. An upward trend is evident around a mean concentration of $6.2 \mathrm{mg} / \mathrm{l}$ at this site. Data from Millington (mean $2.3 \mathrm{mg} / \mathrm{l}$ ) and Chatham (mean $6.0 \mathrm{mg} / \mathrm{l}$ ) are not for sufficiently long a period to develop an observable trend. The Passaic River below the confluence of the Rockaway- 
Whippany Rivers is represented by the Two Bridges site. An upward trend is apparent around a mean of $7.3 \mathrm{mg} / \mathrm{l}$. Data at Pine Brook (mean $12 \mathrm{mg} / \mathrm{l}$ ) are insufficient to establish a signifi-
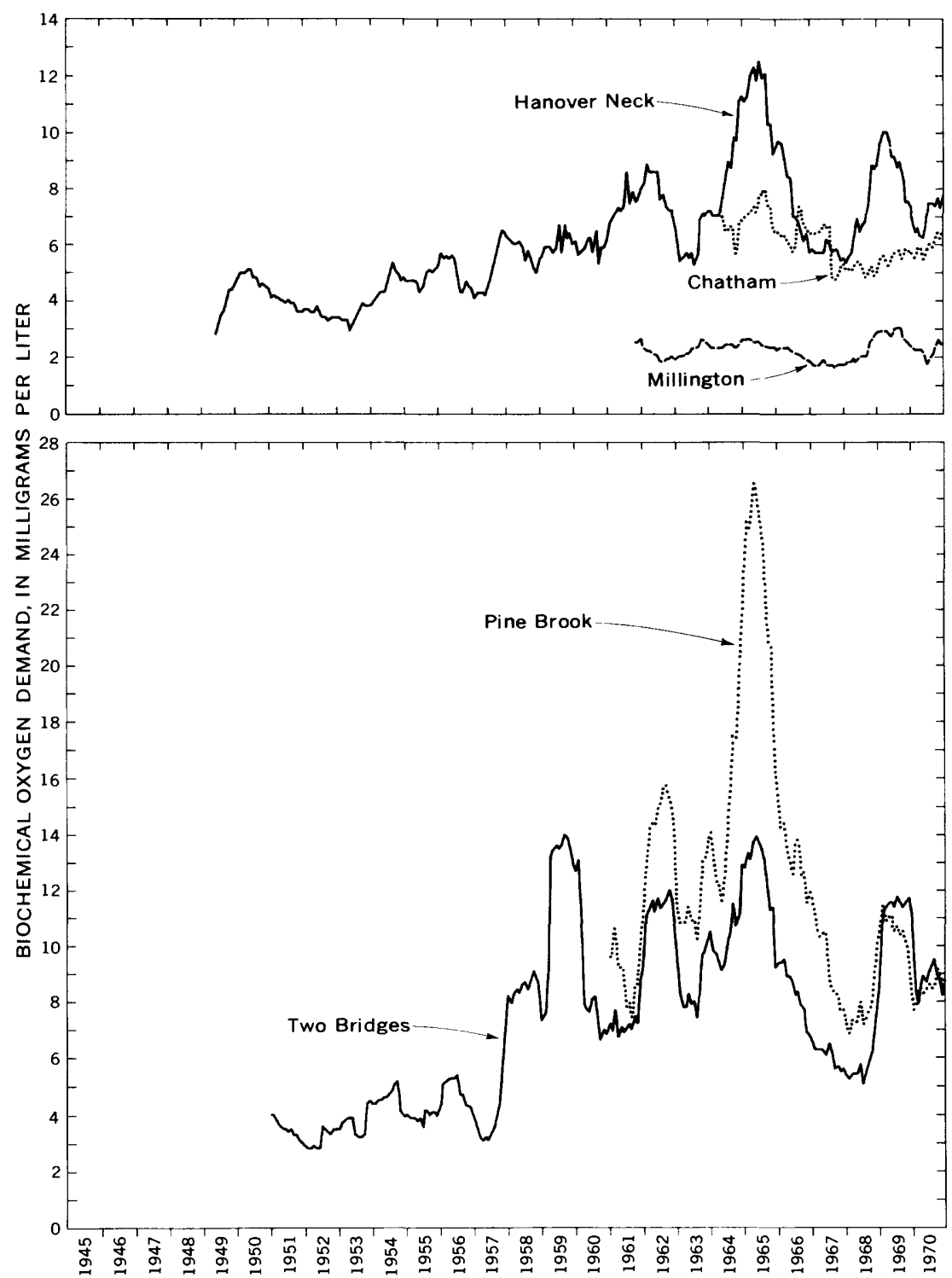

FIGURE 25. - Twelve-month moving average of BOD at selected sampling sites on the Passaic River. (Based on analyses by the Passaic Valley Water Comm.) 
cant trend. The trend at Little Falls (mean $4.6 \mathrm{mg} / \mathrm{l}$ ) is shown in figure 17.

Similar curves (not shown) for the most downstream sampling site on the Rockaway, Whippany, and Pompton Rivers also were prepared. Data on the Rockaway River at Pine Brook indicate an apparent upward trend around a mean of $8.7 \mathrm{mg} / \mathrm{l}$, whereas data on the Whippany River near Pine Brook show an uneven trend around a mean of $20 \mathrm{mg} / 1$. Recent (1971) BOD values at the Whippany River site indicate an improvement in water quality. A similar improvement in oxygen content at this site was noted above. Data on the oxygen demand in the Pompton River at Two Bridges suggest a slight upward trend around a mean of $2.8 \mathrm{mg} / \mathrm{l}$.

In summary, similar moving-average analyses were made of DO and BOD loads at the sites illustrated in figures 24 and 25 and at sites on the major tributaries. Except for the Passaic River at Hanover Neck and the Rockaway River at Pine Brook sampling sites, where downward trends were observed, no apparent longterm upward or downward trends are evident from analyses of DO loads. Analyses of BOD loads did not reveal any definite upward or downward trend with time, which is similar to the pattern for the Little Falls sampling site, discussed at the beginning of this section of the report. The hypothesis put forward for the lack of a trend at Little Falls presumably is true also for these upstream sites.

As an aid in water-quality management, projections can be made for future pollution loads. These projections provide guidance for future waste-water treatment facilities; for dilution requirements; for increasing reservoir storage capacity in order to provide dilution water, particularly during low streamflow; for regulatory purposes; and for other similar needs. One technique for projecting pollution loads consists of a simple extrapolation of present trends. The projection of average BOD loads in the Passaic River at Little Falls to 1980 at long-term average streamflow is shown in figure 26. Because the past increase is reasonably linear, the curve is assumed to extend to 17 tons per day BOD by 1970 , to 21 tons per day by 1980 , and to 30 tons per day by 2000 (not shown). This suggests an almost 200 percent increase between 1964 and 2000 and represents an approximate annual increase of 0.5 tons per day. The apparent discrepancy between this illustration, which projects increasing BOD loads into the future, and figure 17 , which shows relatively constant loads during 1951-70, is explained as follows: The projection illustration is based on long-term ( $67 \mathrm{yr}$ ) average streamflow conditions, whereas figure 17 is based on actual observations during 
a period when streamflow was consistently below the long-term average (fig. 6).

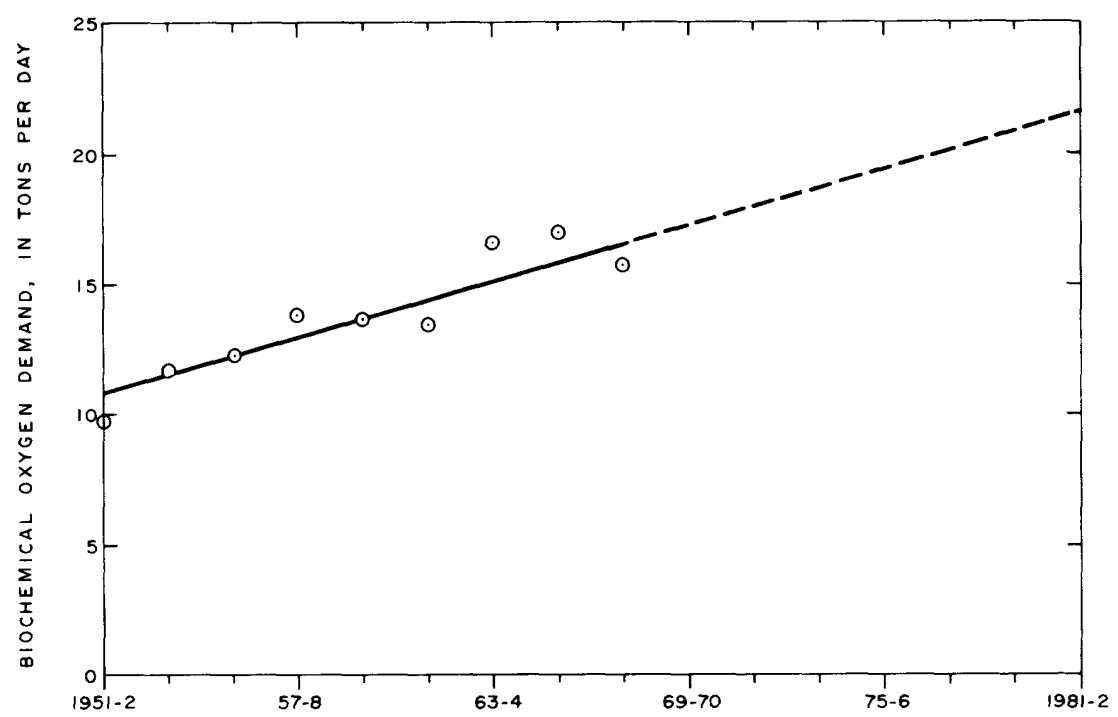

Figure 26. - Projected BOD load in the Passaic River at Little Falls at longterm mean annual streamflow.

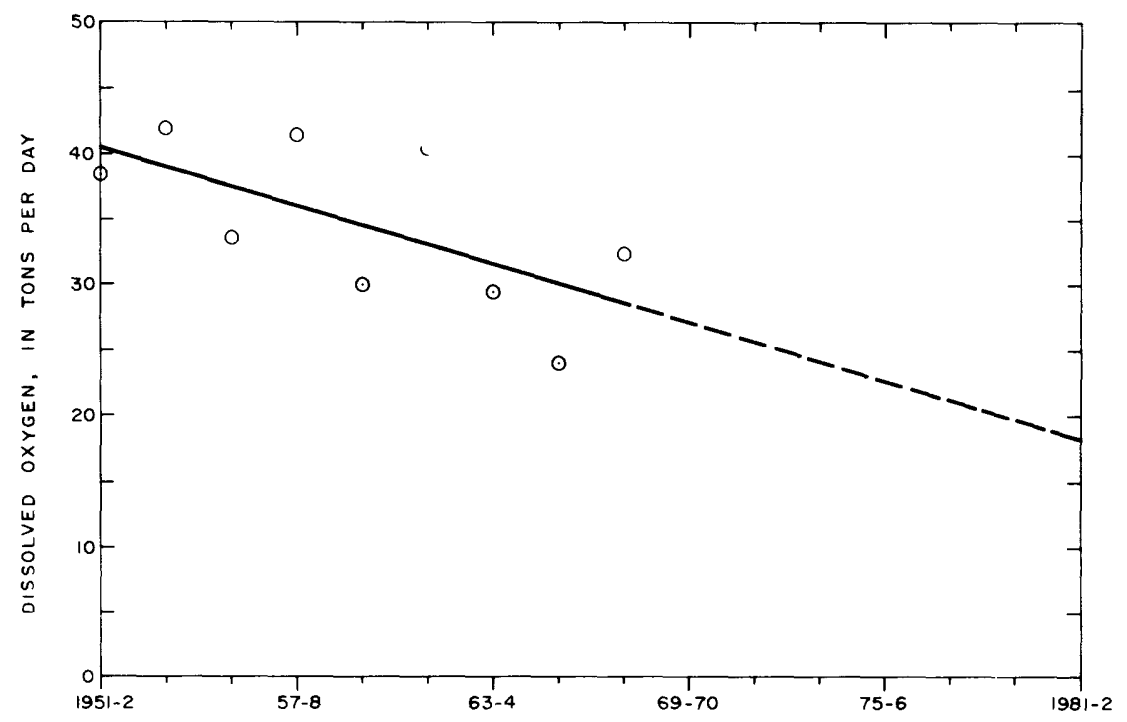

Figure 27. - Projected DO load in the Passaic River at Little Falls at longterm mean annual streamflow. 
A similar projection can be made for DO loads. The projection shown in figure 27 suggests that zero oxygen levels will be approached sometime after 2005. However, to assume that the oxygen load of the river could ever reach zero for extended periods under any conditions would be unrealistic, because photosynthesis and reaeration processes have been neglected in this analysis.

Similar projections could be made for other water-quality parameters, but the above should suffice for illustration.

\section{DECOMPOSITION PRODUCTS}

The primary products of the biochemical decomposition of organic matter are carbon dioxide, ammonia, nitrite, nitrate, hydrogen sulfide, and sulfate. No data were available on hydrogen sulfide. Few useful long-term data were available for a trend analysis of carbon dioxide and sulfate. Values of $\mathrm{pH}$ (table 7) could be used to indicate the presence of carbon dioxide acidity, but these values also would reflect natural variations in other acidic agents of water quality as well. Similarly, sulfate values (table 7) are masked by the naturally occurring ion content. Thus, ammonia, nitrite, and nitrate are the major decomposition products upon which a trend analysis was made. Fortunately, data on these nitrogen species are available from the commission's files.

Several forms of nitrogen occur in water. Gaseous nitrogen is inert and, thus, not important in water quality. However, the combined forms, which may occur in several oxidation states in water, are important. Ammoniacal nitrogen includes nitrogen in the form of ammonia $\left(\mathrm{NH}_{3}\right)$ and the ammonium ion $\left(\mathrm{NH}_{4}{ }^{+1}\right)$. More than $0.1 \mathrm{mg} / \mathrm{l}$ of ammoniacal nitrogen is reported (Rudolph, 1931) to indicate recent organic pollution. Organic, or amino, sometimes called albuminoid nitrogen, includes all nitrogeneous organic compounds. Nitrite and nitrate are the other combined forms of nitrogen. In general, within the stream regimen, the organic nitrogen is converted to ammonia, which is then oxidized to nitrite and, in turn, to nitrate. In spite of their many sources, nitrogen species are seldom abundant in natural waters. Although longterm data were available for the four combined species of the nitrogen cycle, ammonia and nitrate were chosen for trend analysis. Nitrite is extremely unstable in the presence of oxygen and is oxidized almost immediately to nitrate. The biochemical decomposition of nitrogeneous organic compounds converts the organic nitrogen to ammoniacal nitrogen.

Twelve-month moving-average analyses of the ammonia and nitrate content of the Passaic River at Little Falls, expressed in 
concentration and in load units, are illustrated in figures 13 and 14. An apparent upward trend can be noted in the concentrations of ammonia (mean $0.9 \mathrm{mg} / \mathrm{l}$ ) and nitrate (mean $0.6 \mathrm{mg} / \mathrm{l}$ ) and in the load of ammonia being carried past the Little Falls sampling site. Although a definite upward or downward trend in nitrate load is not apparent, when the nitrate-load curve is compared with the curve of streamflow (fig. 6), an upward trend is evident. Consider the comparison during 1952,1960, and 1967, three periods in which peak nitrate loads were observed. In 1952, flow averaged about $1,900 \mathrm{cfs}$, and the nitrate load, about 2.0 tons per day. Similarly, in 1960 the approximate values were $1,200 \mathrm{cfs}$ and 1.7 tons per day, and in 1967, 1,100 cfs and 2.3 tons per day. Thus, whereas average flows in 1960 and 1967 were about the same, loads were 0.6 tons per day higher in 1967. Also, whereas flows in 1952 were almost double those in 1967, loads were higher in 1967. An increase in nitrate load per unit of water discharge is apparent.

Similar analyses were made of data collected at several sampling sites above Little Falls. Curves from the 12-month movingaverage analyses of ammonia and nitrate concentrations are illustrated in figure 28. Although the period of available observations was not as long at these sites as that at Little Falls, the same general pattern is evident-that is, an apparent upward trend in the concentrations of both parameters. The upward trend of nitrate is more obvious than that of ammonia.

Interestingly, the concentration of ammonia increases downstream from Millington (fig. 1, site 2) to Pine Brook (site 16). Below Pine Brook, the concentration of ammonia decreases. Mean concentrations for the same period of observation at each site (1963-70) were Millington $0.3 \mathrm{mg} / \mathrm{l}$, Chatham (site 3 ) $1.2 \mathrm{mg} / \mathrm{l}$, Hanover Neck (site 6) $2.8 \mathrm{mg} / \mathrm{l}$, Pine Brook $3.1 \mathrm{mg} / \mathrm{l}$, Two Bridges (site 18) $3.1 \mathrm{mg} / \mathrm{l}$, and Little Falls (site 30) $1.8 \mathrm{mg} / \mathrm{l}$. Ammonia concentrations in tributary inflows averaged $3.5 \mathrm{mg} / 1$ for the Rockaway River, $2.1 \mathrm{mg} / \mathrm{l}$ for the Whippany River, and $0.3 \mathrm{mg} / \mathrm{l}$ for the Pompton River during the same period. The dilution effect of Pompton River inflow on the ammonia concentration at Little Falls is evident.

A similar increase in nitrate concentration downstream between Millington and Pine Brook is evident, as is a decrease from Pine Brook to Two Bridges. Mean concentrations of nitrate for the same period of observation (1963-70) were Millington $0.5 \mathrm{mg} / \mathrm{l}$, Chatham $0.7 \mathrm{mg} / \mathrm{l}$, Hanover Neck $0.9 \mathrm{mg} / \mathrm{l}$, Pine Brook $0.8 \mathrm{mg} / \mathrm{l}$, Two Bridges $0.7 \mathrm{mg} / \mathrm{l}$, and Little Falls $0.8 \mathrm{mg} / \mathrm{l}$. Nitrate concentrations in inflow from the Rockaway River averaged $0.5 \mathrm{mg} / \mathrm{l}$; from the Whippany River, $1.0 \mathrm{mg} / \mathrm{i}$; and from the Pompton River, 

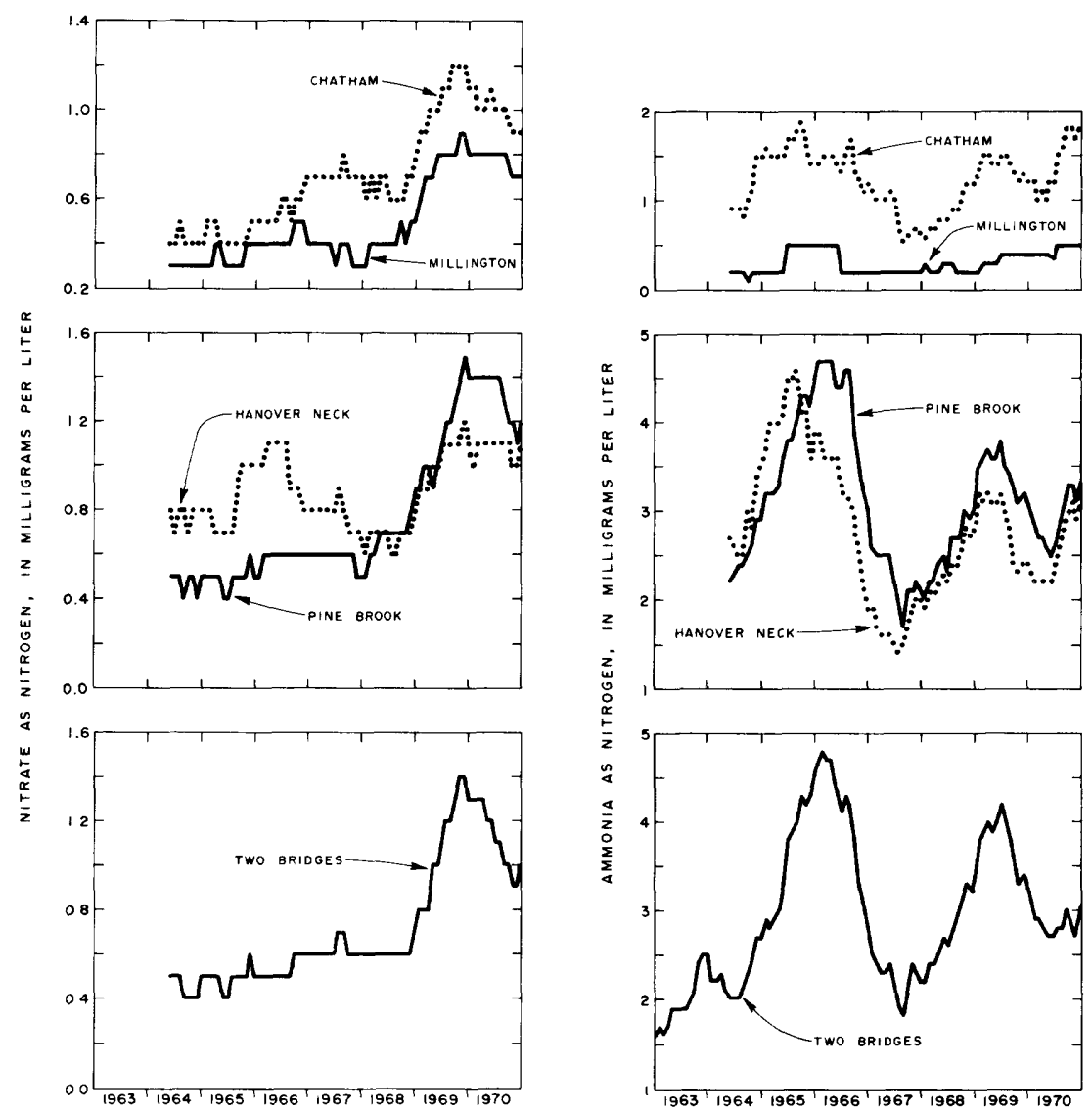

FIGURE 28. - Twelve-month moving average of ammonia and nitrate at several sampling sites on the Passaic River. (Based on analyses by the Passaic Valley Water Comm.)

$0.8 \mathrm{mg} / \mathrm{l}$ during the same period. A significant observation here is that the ratio of ammonia to nitrate is lower at Little Falls (2.3) than at Two Bridges (4.4), Pine Brook (3.9), and Hanover Neck (3.1). Only at Millington (ratio 0.6) is the nitrate content in excess of or equal to the ammonia content. The increase in the ammonia-nitrate ratio from Millington to Pine Brook followed by a decrease below Pine Brook suggests that ammonia is being oxydized to nitrate in the Passaic River system and that the process contributes substantially to the continued undersaturation of DO noted earlier (fig. 17) at Little Falls.

Similar trends and profiles were observed when 12-month moving-average analyses were made of ammonia and nitrate loads. 


\section{COLIFORM GROUP OF BACTERIA}

Trend analyses also were made of coliform bacteria, expressed in statistical units of most probable number per 100 milliliters. Examples of the curves derived by 12-month moving-average analyses of data collected at six sampling sites on the Passaic River main stem are presented in figure 29. In all examples the general trend in coliform-bacteria counts was upward. The increase in bacteria counts with time is another indication that waste-water discharge to the river system is increasing.

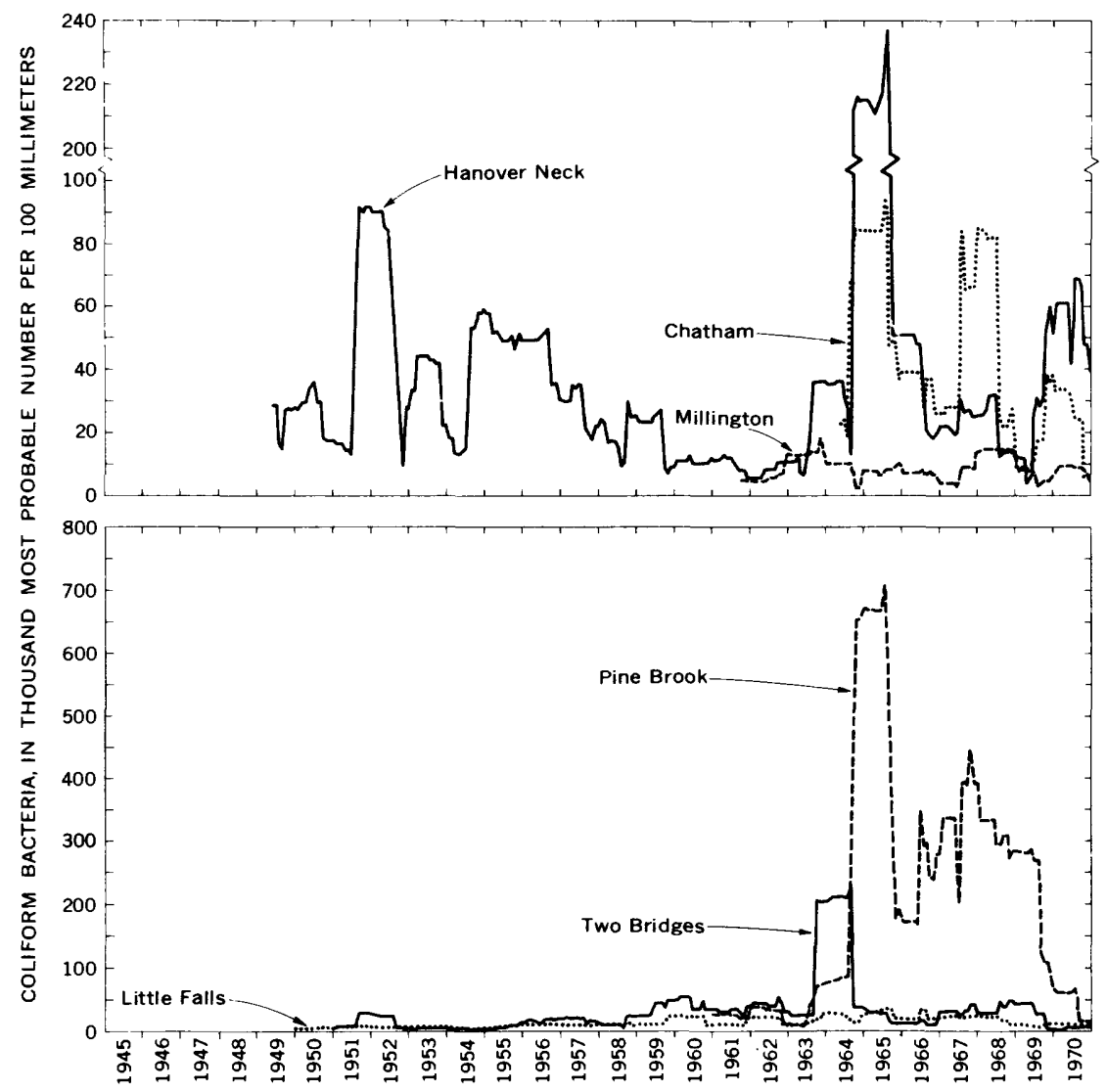

Figure 29. - Twelve-month moving averages of coliform-bacteria counts at several sampling sites on the Passaic River. (Based on analyses by the Passaic Valley Water Comm.)

\section{PHYSICAL CHARACTERISTICS}

As indicated earlier, color, turbidity, temperature, and amount of suspended material are considered to be physical characteristics 
of water quality. Records of color were summarized in table 7 for several representative sampling sites in the basin. Color ranges from 1 to 100 platinum-cobalt units, except in areas draining swamps or lowlands, where the maximum color often exceeds 100 units but is seldom more than 150 units.

Interestingly, a double-mass-curve analysis of daily air temperatures and concurrent water temperatures on the Passaic River at Little Falls showed no change in relation during 1950-70 (fig. 30). Thus, presumably no significant increase in thermal loading has occurred in the river system upstream from Little Falls, except possible loading so far upstream as to be dissipated by natural processes.

Double-mass-curve analysis is used to check the consistence of many kinds of hydrologic data. Such analysis involves the graphing of cumulative data of one variable versus the cumulative data

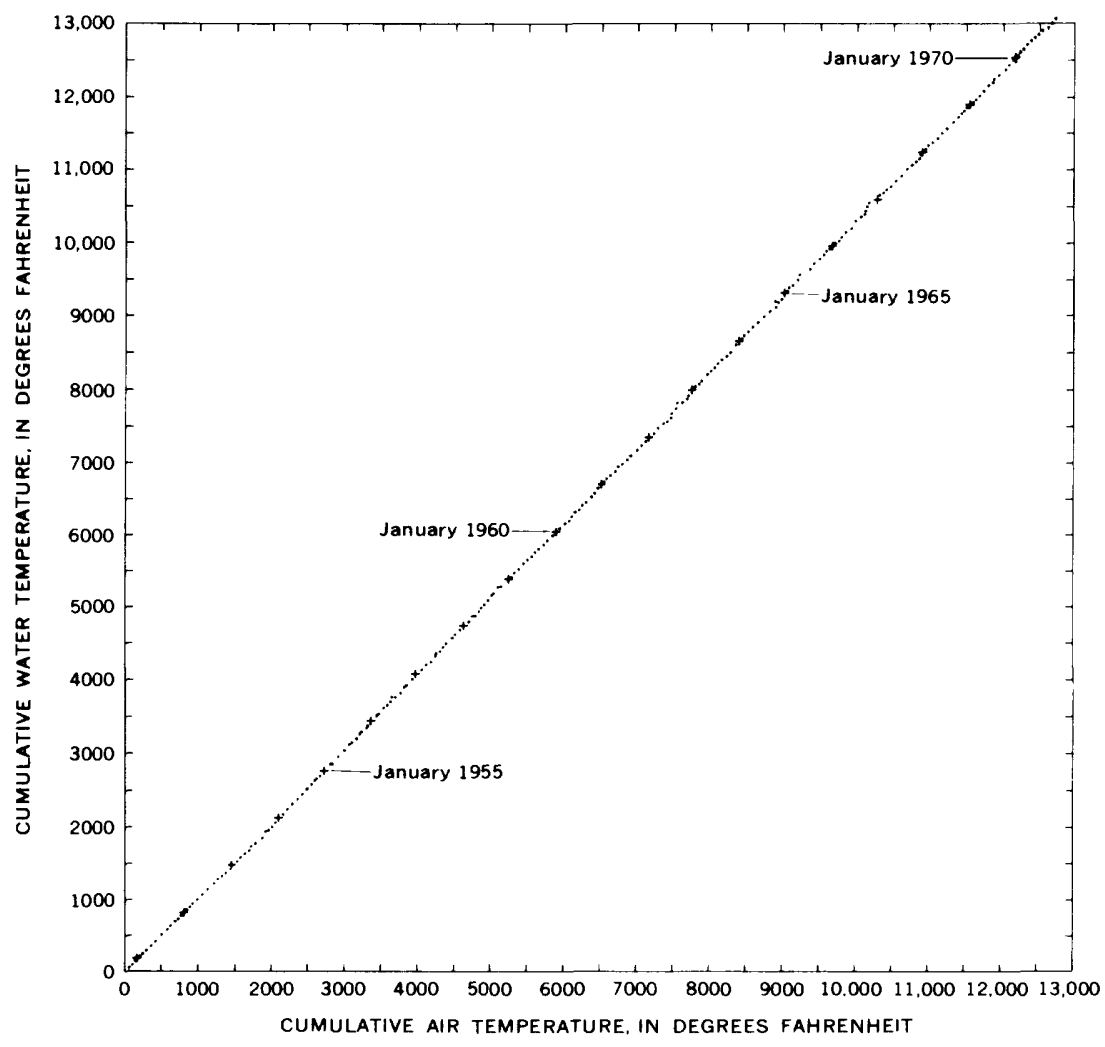

Figure 30. - Double-mass curves of air and water temperatures at Little Falls. 
of a related variable. A straight-line relation is obtained so long as the relation between the variables is a fixed ratio. Breaks in the slope of the double-mass curve are caused by changes in the ratio between the variables. Techniques and statistical significance of double-mass-curve analysis were described by Searcy and Hardison $(1960)$.

Stream sedimentation has been an important water-quality parameter to agricultural experts for many years. It is a significant factor to be considered in any investigation of soil-conservation practices. More recently-perhaps within the last $10-20$ years - the significance of a basic knowledge of stream sedimentation to public-water-supply superintendents, engineers who construct reservoirs or maintain navigable channels, fishery biologists, and water-pollution-control officials has increased tremendously.

Anderson and George (1966, p. G38) estimated that annual sediment yield in the Passaic River basin ranges from 75 to 500 tons per square mile. This appraisal was based on both streamsedimentation and stream-turbidity data. Although the data were scant, Anderson and George believed that the values were in the correct order of magnitude.

Suspended-sediment samples were collected during the period of the present study at three locations to estimate basin sediment yields. The three sampling sites-Ramapo River near Mahwah (fig. 1, site 27), Passaic River near Chatham (site 3), and Passaic River at Little Falls (site 31) -were established at streamflowgaging stations to determine the sediment-discharge-water-discharge relations. A summary of monthly sediment discharges is given in table 10 .

Sediment-transport curves were drawn on the basis of monthly sediment discharge and water discharge for each sampling site (fig. 31). The steep slope of these curves shows that the rate of sediment discharge changes rapidly with small changes in streamflow, approximately as a second-power function of water discharge.

TABLE 10. - Observed monthly and annual suspended-sediment

\begin{tabular}{|c|c|c|c|c|c|c|}
\hline Location (fig. 1) & Year & Jan. & Feb. & Mar. & Apr. & $\overline{\text { May }}$ \\
\hline $\begin{array}{c}\text { Passaic River near } \\
\text { Chatham (site } 3 \text { ) }\end{array}$ & $\begin{array}{l}1963 \\
1964 \\
1965 \\
1966 \\
1967 \\
1968\end{array}$ & $\begin{array}{r}1312.0 \\
136.6 \\
111.5 \\
590.1 \\
265.3\end{array}$ & $\begin{array}{r}582.6 \\
1840.6 \\
1297.4 \\
159.4 \\
287.3\end{array}$ & $\begin{array}{r}522.2 \\
675.3 \\
610.4 \\
1469.0 \\
1433.9\end{array}$ & $\begin{array}{r}1002.8 \\
233.4 \\
315.5 \\
471.3 \\
593.6\end{array}$ & $\begin{array}{r}217.8 \\
177.8 \\
979.0 \\
765.4 \\
3244.0\end{array}$ \\
\hline $\begin{array}{l}\text { Ramapo River near } \\
\text { Mahwah (site 27). }\end{array}$ & $\begin{array}{l}1964 \\
1965\end{array}$ & 51.9 & 1281.6 & $\begin{array}{r}326.3 \\
92.3\end{array}$ & $\begin{array}{r}407.7 \\
58.2\end{array}$ & $\begin{array}{r}100.1 \\
57.6\end{array}$ \\
\hline $\begin{array}{l}\text { Passaic River at Little } \\
\text { Falls (site } 31 \text { ). }\end{array}$ & $\begin{array}{l}1963 \\
1964 \\
1965\end{array}$ & $\begin{array}{r}3681.0 \\
242.0\end{array}$ & $\begin{array}{l}1093.0 \\
5246.0\end{array}$ & $\begin{array}{r}1069.0 \\
818.0\end{array}$ & $\begin{array}{r}2430.0 \\
397.0\end{array}$ & $\begin{array}{l}783.0 \\
233.0\end{array}$ \\
\hline
\end{tabular}




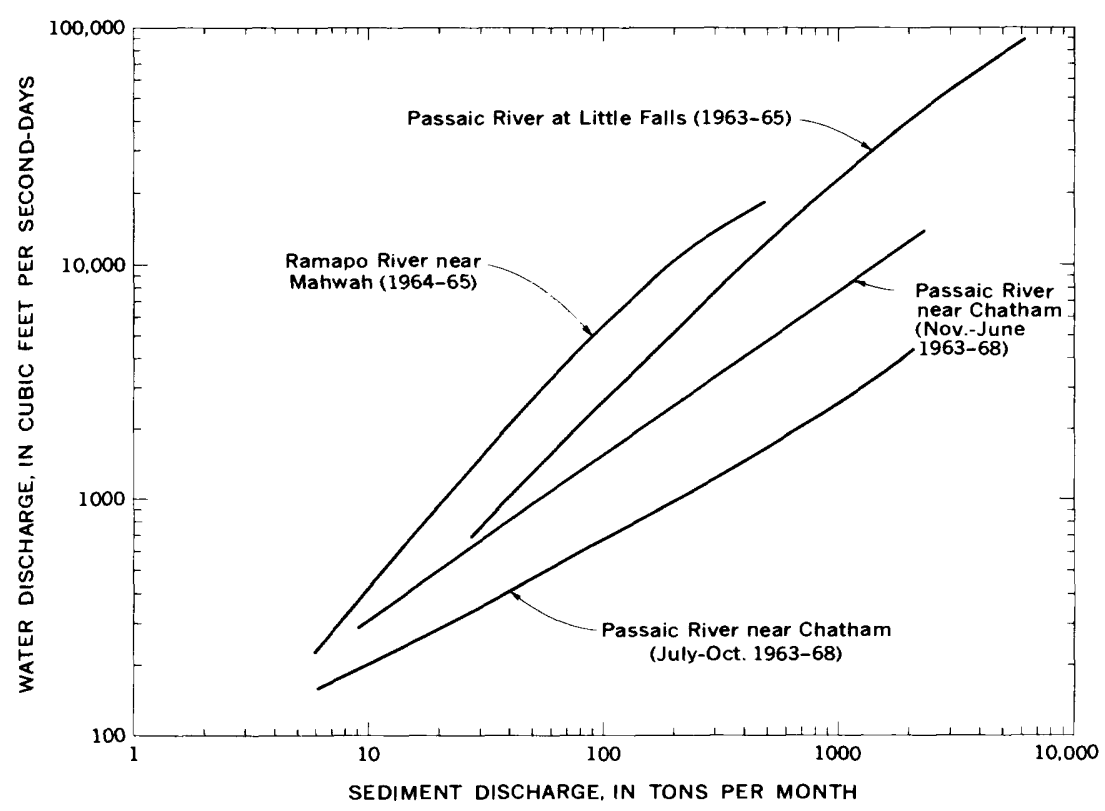

FIGURE 31. - Relation between sediment discharge and water discharge for three sampling locations.

Several environmental factors control soil erosion and the delivery of suspended sediment to the basin's streams. The more significant variables include physical characteristics of the soils, land slope, land use or vegetal cover, extent of precipitation and direct runoff, and capacity of the surface drainage system to transport fine sediments in suspension.

The role of some of these environmental factors can be shown by means of the transport curves. For example, in the glaciated New England Upland section (fig. 12), represented by the Ramapo River sampling site, erosion rates and, consequently, suspendedsediment concentrations in streams are comparatively low. Poor

discharge, in tons, in the Passaic River basin, 1963-68

\begin{tabular}{|c|c|c|c|c|c|c|c|}
\hline June & July & Aug. & Sept. & Oct. & Nov. & Dec. & Annual \\
\hline $\begin{array}{r}49.3 \\
18.1 \\
160.0 \\
156.8 \\
1928.0\end{array}$ & $\begin{array}{r}54.8 \\
44.4 \\
20.2 \\
1101.5 \\
144.6\end{array}$ & $\begin{array}{r}32.5 \\
22.2 \\
151.4 \\
39.7 \\
1859.3 \\
563.6\end{array}$ & $\begin{array}{r}212.8 \\
9.1 \\
44.6 \\
1219.8 \\
130.9 \\
225.3\end{array}$ & $\begin{array}{r}46.5 \\
7.2 \\
137.8 \\
531.5 \\
272.6 \\
\ldots \ldots\end{array}$ & $\begin{array}{r}954.0 \\
18.8 \\
17.0 \\
309.8 \\
121.7 \\
\ldots . .\end{array}$ & $\begin{array}{r}251.6 \\
258.3 \\
78.5 \\
327.3 \\
1171.5 \\
\ldots .\end{array}$ & $\begin{array}{r}4057 \\
3555 \\
5922 \\
8270 \\
\ldots .\end{array}$ \\
\hline 83.8 & 24.7 & 18.0 & 12.2 & 10.3 & 23.1 & 57.2 & .... \\
\hline$\cdots$ & $\cdots$ & $\ldots$ & $\cdots$ & $\cdots$ & $\cdots$ & $\cdots$ & .... \\
\hline $\begin{array}{r}360.0 \\
88.0\end{array}$ & $\begin{array}{r}359.0 \\
\ldots . .\end{array}$ & $\begin{array}{r}82.0 \\
\ldots . .\end{array}$ & $\begin{array}{r}39.0 \\
\ldots .\end{array}$ & $\begin{array}{r}93.0 \\
86.0 \\
\ldots .\end{array}$ & $\begin{array}{r}1714.0 \\
194.0 \\
\ldots\end{array}$ & $\begin{array}{r}696.0 \\
834.0 \\
\ldots . .\end{array}$ & $\begin{array}{r}11010 \\
\ldots\end{array}$ \\
\hline
\end{tabular}


surface drainage characteristics, which were developed in part by Pleistocene glaciation, combine with rather dense vegetal cover to produce comparatively low yields of sediment to local streams. Anderson and George (1966, p. G38) estimated annual yields of only 10-100 tons per square mile for this area. Generally, in the Piedmont Lowland section, represented by the Passaic River sampling sites, an abundance of silt- and clay-size sediments in the soils, moderate land slopes, and less vegetal cover produce a higher sediment yield. Typical streams draining the Piedmont Lowland often remain slightly turbid for relatively long periods after direct runoff. The greater transport of suspended sediment for a given water discharge observed at the Passaic River sampling sites in relation to that observed at the Ramapo River site suggests that the primary controlling factors explaining the differences in transport capability of these streams are soil characteristics, land slopes, and vegetal cover.

The greater transport of suspended sediment per unit of flow at the Chatham sampling site in relation to the Little Falls site may be due in part to greater urban land-use changes-that is, more recent and current residential and highway construction in the upper basin. A seasonal variation in sediment transport has been noted also at the Chatham sampling site. In general, higher sediment transport per unit of flow is observed during the summer period (July to Oct.). This is probably related to the greater length of time between summer storms and, thus, a greater possibility for the accumulation of debris and dry, loose soils. The occasional summer storms, usually of higher intensity than those at other times, flush this accumulated material from the banks into the streams. The higher sediment transport in summer may also be related to the increased urbanization of the area and the temporary exposure of soils during construction, because much earth moving for construction occurs during mild weather.

Sediment-transport curves define an approximate sedimentwater discharge relation, from which an estimate of the expected long-term frequency of sediment yield can be made on the basis of flow-probability analyses. Flow-duration information (1945-70) for these three stations ( table 5. Using this information and the transport curves, the expected frequency of a particular sediment discharge can be estimated. Estimates of sediment discharges expected to be equaled or exceeded $10,25,50,75$, and 90 percent of the time are given in table 11.

Expected long-term average annual yields can be computed from long-term average streamflow (table 3 ). Thus, annual yields from 
TABLE 11. - Estimated frequency of suspended-sediment discharges, in tons per day, at three sampling sites in the Passaic River basin

\begin{tabular}{|c|c|c|c|c|c|}
\hline \multirow{2}{*}{$\begin{array}{l}\text { Location } \\
\text { (fig. 1) }\end{array}$} & \multicolumn{5}{|c|}{$\begin{array}{c}\text { Sediment discharge equaled or exceeded the indicated percentage } \\
\text { of time }\end{array}$} \\
\hline & 10 & 25 & 50 & 75 & 90 \\
\hline $\begin{array}{l}\text { Passaic River near } \\
\text { Chatham (site } 3 \text { ) }\end{array}$ & 146 & 47 & 13 & 2.5 & 0.7 \\
\hline $\begin{array}{l}\text { Ramapo River near } \\
\text { Mahwah (site 27) ............. } \\
\text { Passaic River at Little }\end{array}$ & 11 & 4.9 & 2.4 & 1.2 & .6 \\
\hline Falls (site 31) & 133 & 70 & 21 & 8.0 & 3.8 \\
\hline
\end{tabular}

the Ramapo River basin above the Mahwah sampling site are estimated to average 1,400 tons per year (12 tons per sq $\mathrm{mi}$ ); from the Passaic River basin above the Chatham site, 8,000 tons per year ( 80 tons per sq $\mathrm{mi}$ ) ; and above Little Falls, 20,000 tons per year (26 tons per sq $\mathrm{mi}$ ). A comparison of the measured sediment yields during the study period (table 10) with expected average annual yield shows that the measured yields were generally much lower than the estimated long-term annual yield. Streamflows during much of the period were extremely low because of extreme drought during 1961-66. The differences in sediment yields are attributed to these lower water yields. Thus, one beneficial effect of the drought was the reduction of sediment yields.

Although stream-sediment transport characteristics for streams in the Passaic River basin are available for only three sampling sites, a great deal of information is available on stream turbidity. Turbidity is a measure of the ability of water to transmit or to scatter light. Although not a quantitative measure of the amount of suspended solids in the water, it has been used to estimate the gross sediment content. For example, Anderson and George (1966, p. G40) illustrated a significant relation between turbidity and sediment concentration in the Delaware and the South Branch Raritan Rivers. However, attempts to relate sediment concentration and turbidity significantly at sampling sites in the Passaic River basin proved unsuccessful. This was probably due to the fact that sediment concentrations reported herein reflect primarily mineral and rock fragments rather than organic materials, flocs, and other materials in waste-water discharges, whereas turbidity measurements reflect both agents. However, turbidity can be used to illustrate the increasing influence of man's activities in this basin on the gross sediment-pollution loads. Figure 32 illustrates the increasing values of stream turbidity, based on 12-month moving-average analysis, in the Passaic River at Little Falls. Note that even during the drought of 1961-66 the average stream turbidity increased. This is probably a reflection of an increased percentage of waste water in the river system in relation to total streamflows. 


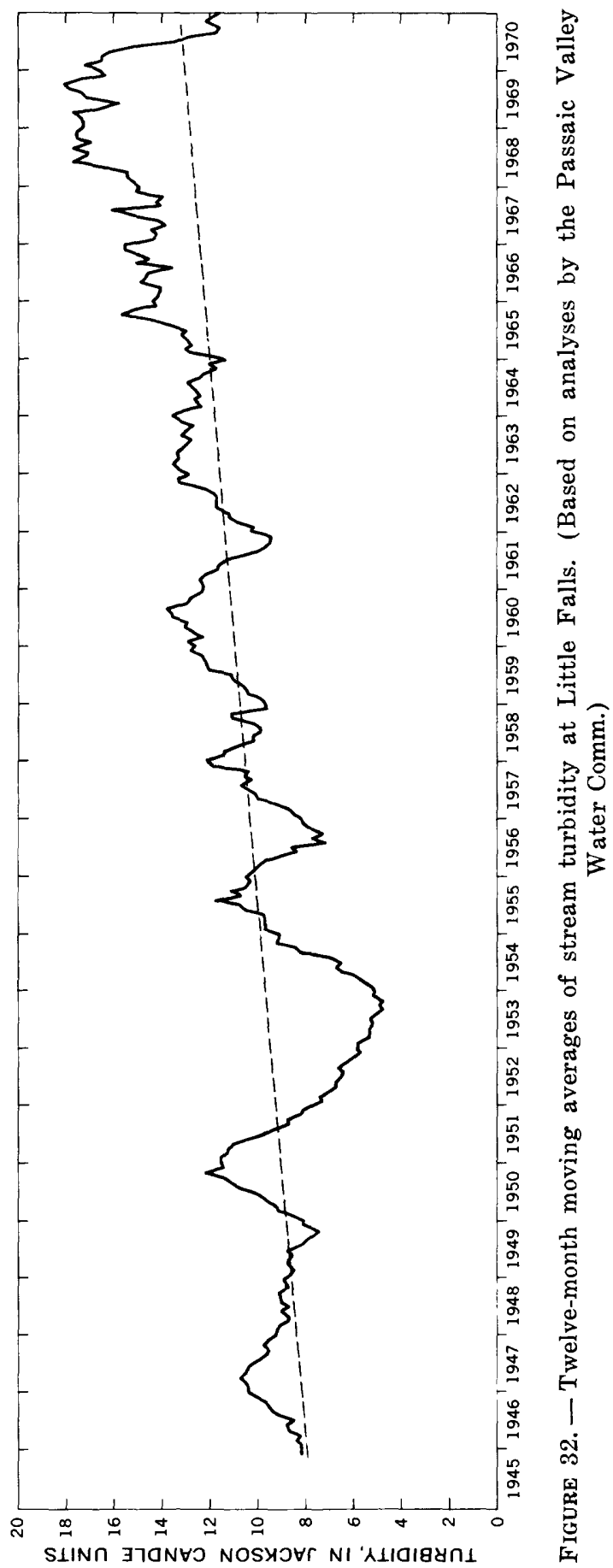


In addition to the determination of sediment concentration and load, several samples were analyzed for particle-size distribution. A comparison was made by relating each size distribution to its corresponding water discharge and then grouping the discharges into two ranges-discharges equaled or exceeded 10 percent of the time (high) and those equaled or exceeded 60 percent of the time (low). The average particle-size distribution for the high streamflow ranges (at all stations) and for the low ranges (Chatham only) are illustrated in figure 33. The American Geophysical Union's classification of particle size is used in this illustration. Particles with diameters between 0.0002 and 0.004 millimeters are classified as clay; between 0.004 and 0.062 millimeters, as silt; and between 0.062 and 2.0 millimeters, as sand.

A comparison of the curves in this illustration shows that at the Chatham sampling site clay makes up about 55 percent of the suspended sediments during high storm discharges; silt, 40 percent; and sand, 5 percent. During low storm discharges, clay constitutes 72 percent of the suspended sediment; silt, 27 percent; and sand, only 1 percent. Thus, clay makes up the major part of suspended sediments carried at both discharge rates.

Similarly, at the Little Falls site, clay constitutes about 27 percent during high discharges; silt, 71 percent; and sand, only 2 percent. Also note that at both Passaic River sites the percentage of sand is relatively small. However, at the Mahwah site, clay constitutes about 22 percent during high discharges; silt, 48 percent; and sand, 30 percent of the sediments in suspension.

In many areas the sediment yields from a large region can be estimated by sampling a small part of that region. This can be done where the hydrologic characteristics of the region are approximately homogeneous. However, the Passaic River basin cannot be considered homogeneous because of the influences of reservoirs, swamps, topographic variations, and urbanization. The measured sediment discharges are representative only of the area directly upstream from the gaged site. To define the sediment yield in other parts of the basin, a much larger sampling program would be needed.

\section{SUMMARY}

The Passaic River at Little Falls, N.J. (760 sq-mi drainage area), represents the accumulated drainage of approximately 80 percent of the total basin's area $(950 \mathrm{sq} \mathrm{mi})$. Although some recreational and agricultural uses are found in the headwater areas, the streams are used principally as a source of water supply-in 1970, 10 water-supply purveyors used the basin's streams as a source to produce potable water-and as a medium for the disposal of 


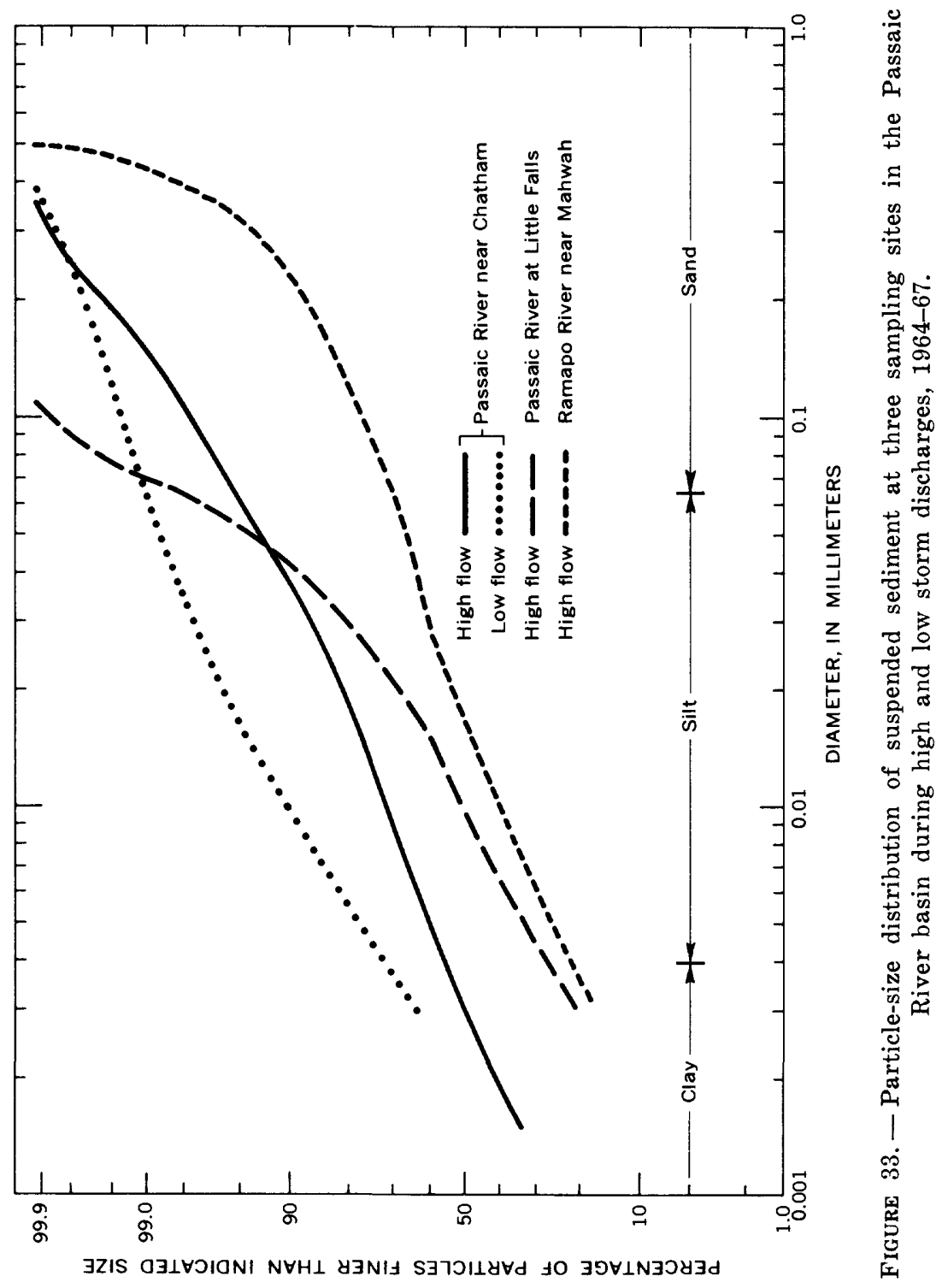


waste waters-in 1970 , almost 160 waste-water treatment plants used the streams as a receptor for their effluents. Such uses of the basin's streams have been extremely heavy during recent yearsfor example, in 1970, potable-water diversions at and above Little Falls amounted to about $320 \mathrm{mgd}$, and treatment-plant effluents amounted to about $60 \mathrm{mgd}-$ and a continued rapid expansion is projected for the future. To meet these present and future water demands, efficient and prudent water-resource management by action agencies is a necessity.

Precipitation in the basin is classified as ample in climatic terms (Dunlap, 1966, p. 19) and averages about 47 inches per year, or roughly 3-5 inches per month. There were five general trends (fig. 4) during the period of study (1945-70). Precipitation was approximately normal until 1950, was higher than normal between 1950-52, completed a slow change from higher than normal to less than normal between 1952-62, had an extremely large deficiency during the drought of 1962-66, and returned to near normal after 1966. Interestingly, both the maximum (58.4 in.) and the minimum (30.5 in.) annual precipitation recorded since 1929 was recorded during the study period.

Trends in streamflow are illustrated (fig. 6) for 10 gaging stations on the Passaic River main stem and its two major tributary systems, the Rockaway-Whippany and the Pompton River systems. In general, the highest 12-month average flows were observed in 1952, concurrent with the maximum annual precipitation, whereas the lowest were observed in 1965 , concurrent with the minimum annual precipitation. A direct relation between precipitation and streamflow is evident.

A generalized plot (fig. 11) of dissolved solids and streamflow, given for four sampling sites on the main stem, illustrates the indirect relation that exists in the concentration of solutes with flow. Similar relations were found to exist between streamflow and several individual constituents or properties, such as calcium, magnesium, sodium, potassium, bicarbonate, sulfate, chloride, and hardness.

For water quality evaluation, the Passaic River basin was divided into five general isochemical regions on the basis of predominant chemical constituents and dissolved solids, as measured during low streamflow at 80 sampling sites. Because, under natural conditions, the major part of low streamflow in gaining streams is caused by ground-water inflow, the mapped water types normally reflect the chemical quality of influent ground water. However, comparison of the chemical-quality map with the physiographic boundary suggests that the natural solute-solvent relation 
has been altered; that is, the chemical weathering in the geologic environment may not be the predominant causative factor influencing stream quality.

The predominant cations found in the basin's streams during low flow are the alkaline earths. Calcium plus magnesium, in terms of total cation content, usually exceeds 50 percent. Only in one region, where man's activities probably have altered the chemistry of the stream waters, does the percentage of alkaline earths nearly equal the percentage of alkali metals. In two of the five regions, the predominant anions are those associated with alkalinity. Bicarbonate usually exceeds 50 percent of the total anion content in these two regions. Anions associated with salinity are predominant in the other three regions. Sulfate is the major anionic component of streams draining one of the three regions, often exceeding 30 percent of the total, whereas the predominant anions in the other two regions are a combination of sulfate, chloride, and nitrate. The chemistry of stream water in the latter two regions is influenced greatly by man's activities. Dissolvedsolids content varies greatly throughout the basin during low flow, generally ranging from 100 to $600 \mathrm{mg} / \mathrm{l}$ but occasionally being higher in certain areas.

Long-term trends in the concentration (fig. 13) and load (fig. 14) of dissolved solids, hardness, chloride, sulfate, nitrate, and ammonia on the Passaic River at Little Falls are illustrated by means of 12-month moving averages. Although an upward trend in the concentration of these parameters with time is suggested from the moving-average curves, comparison of these curves with a similar plot of discharge (fig. 6) indicates that the rising trend in concentration may be related to the concurrent decrease in streamflow. Similarly, suggested decreasing trends in the load of dissolved materials accumulated in the river system and carried past the Little Falls sampling station can be explained by the concurrent decrease in flow.

Linear-regression analysis (fig. 15) of dissolved solids and streamflow was used to test the trend in dissolved solids per unit volume of water. If regressions of 2-year groups of the data are compared, dissolved-solids content of the river water at Little Falls is shown to increase with time.

Because a trend has been demonstrated for dissolved materials at Little Falls, similar trends are assumed to occur on the main stem and major tributary systems above Little Falls. As a partial test of this assumption, using chloride as an indicator, 12-month moving-average analyses (fig. 16) were used to establish suggested general trends in the basin above Little Falls. Upward 
trends in chloride content were noted in streamflow at sampling sites on the main stem between Millington (drainage area 50 sq $\mathrm{mi}$ ) and Little Falls (760 $\mathrm{sq} \mathrm{mi}$ ) and in the inflow from the Rockaway-Whippany and Pompton River systems. Assuming that chloride is a general indicator of the major chemical-quality parameters at these sampling sites-and data presented in table 7 indicate that such an assumption is probably valid-the dissolved material carried by the main stem and by influent waters from the major tributary systems is also increasing with time, but at varying rates.

Similar analyses were made of several biochemical water-quality parameters-DO, BOD, nitrate, ammonia, and bacteria. In general, these trend analyses indicated a deterioration in stream quality at main-stem and tributary sampling sites. The water is undersaturated with respect to DO (figs. 17 and 24) at all sites, and DO is decreasing with time at most sites. BOD (figs. 17 and 25) is increasing with time at most sampling sites, suggesting an increase in the organic-chemical loads carried by the river system.

Interestingly, the BOD concentration at Little Falls is related inversely to streamflow (fig. 18) and is generally highest during the first calendar quarter and lowest in the third quarter (fig. 19). However, DO is directly related to streamflow (fig. 20) and also tends to be highest in the first calendar quarter and lowest in the third (fig. 21).

Analyses of nitrate and ammonia content also indicated a general increase with time at most sampling sites (figs. 13 and 28). Decreasing ratios of ammonia to nitrate in a downstream direction on the Passaic River main stem suggest that nitrification as well as microbiological decomposition of organic matter is contributing to the continued and increasing undersaturation of DO in the river system. Coliform-bacteria trends (fig. 29) also suggest increasing pollution loads in the river system.

References to physical water-quality parameters are brief, primarily because of the scant data available. Such physical properties as color are summarized in table 7 ; temperature, in figure 30 ; turbidity, in figure 32 ; and suspended sediment, in tables 10 and 11 and figures 31 and 33 .

Several time-of-travel measurements within the basin (table 6) provided reasonable estimates of the traveltime required for soluble contaminants to pass through particular parts of the river system. For example, the peak concentration of a contaminant injected into the river system during extremely low streamflow at Chatham would be expected to travel the entire 30.9 miles to the Passaic Valley Water Commission's intake at Little Falls in 
approximately 13 days, but at medium flow traveltime would be reduced to about 5 days.

\section{REFERENCES}

Anderson, P. W., 1970, Occurrence and distribution of trace elements in New Jersey streams: New Jersey Div. Water Policy and Supply, Water Resources Circ. 24, 24 p.

Anderson, P. W., and Faust, S. D., 1965, Changes in quality of water in the Passaic River at Little Falls, New Jersey, as shown by long-term data, in Geological Survey research 1965: U.S. Geol. Survey Prof. Paper 525-D, p. D214-D218.

Anderson, P. W., and George, J. R., 1966, Water-quality characteristics of New Jersey streams: U.S. Geol. Survey Water-Supply Paper 1819-G, $48 \mathrm{p}$.

Anderson, P. W., and McCall, J. E., 1968, Effect of drought on stream quality in New Jersey: Amer. Soc. Civil Engineers Proc., Jour. Sanitary Eng. Div., v. 94, no. SA5, p. 779-788.

Barksdale, H. C., O'Bryan, Deric, and Schneider, W. J., 1966, Effect of drought on water resources in the northeast: U.S. Geol. Survey Hydrol. Inv. Atlas HA-243.

Barnett, P. R., and Mallory, E. C., Jr., 1971, Determination of minor elements in water by emission spectroscopy: U.S. Geol. Survey Techniques WaterResources Inv., book 5, chap. A2, 31 p.

Bromberg, A. W., 1969, Report on the quality of the interstate waters of the lower Passaic River: Federal Water Pollution Control Admin., Conference in the matter of pollution of the interstate waters of the Hudson River and its tributaries-New York-New Jersey, 3d session (reconvened), Newark, N.J., Nov. 1969, Proc., p. 19-105.

Buchanan, T. J., 1964, Time of travel of soluble contaminants in streams: Am. Soc. Civil Engineers Proc., Jour. Sanitary Eng. Div., v. 90, no. SA3, p. 1-12.

Churchill, M. A., Elmore, H. L., and Buchingham, R. A., 1962, The prediction of stream reaeration rates: Am. Soc. Civil Engineers Proc., Jour. Sanitary Eng. Div., v. 88, no. SA4, p. 1-46.

Collins, W. D., and Howard, C. S., 1927, Quality of the surface waters of New Jersey: U.S. Geol. Survey Water-Supply Paper 596-E, p. 89-119.

Dunlap, D. V., 1966, Climate and weather limitations to water replenishment, in Proceedings of Rutgers public policy forum on New Jersey water resources: New Brunswick, N.J., Rutgers-The State Univ., Coll. Agr. and Environmental Sci., p. 19-28.

Faust, S. D., Stutz, Hansjakob, Aly, O. M., and Anderson, P. W., 1971, Recovery, separation, and identification of phenolic compounds from polluted waters: New Jersey Water Resources Research Institute, 56 p.

Hely, A. G., Nordenson, T. J., and others, 1961, Precipitation, water loss, and runoff in the Delaware River basin and New Jersey: U.S. Geol. Survey Hydrol. Inv. Atlas HA-11, 11 p.

Laskowski, S. L., 1970, Statistical summaries of New Jersey streamflow records: New Jersey Div. Water Policy and Supply, Water Resources Circ. 23, $264 \mathrm{p}$.

Leighton, M. O., 1902, Sewage pollution in the metropolitan area near New York City and its effect on inland water resources: U.S. Geol. Survey Water-Supply Paper 72, $75 \mathrm{p}$. 
Palmer, W. C., 1965, Meteorological drought: U.S. Weather Bur., Research Paper 45, $58 \mathrm{p}$.

1967, The drought problem: Amer. Soc. Civil Engineers Proc., Annual meeting, New York City.

Pritchard, D. W., and Carpenter, J. H., 1960, Measurements of turbulent diffusion in estuarine and inshore waters: Internat. Assoc. Sci. Hydrology Bull. 20, p. 37-50.

Rudolph, W., 1931, Principles of the determination of the physical and chemical standards of water for drinking, industrial, and domestic purposes: Water Pollution Abs., no. 4.

Searcy, J. K., 1959, Flow-duration curves: U.S. Geol. Survey Water-Supply Paper 1542-A, 33 p.

Searcy, J. K., and Hardison, C. H., 1960, Double-mass curves: U.S. Geol. Survey Water-Supply Paper 1541-B, p. 31-66.

Steel, R. G. D., and Torrie, J. H., 1960, Principles and procedures of statistics: New York, McGraw-Hill Book Co., 481 p.

U.S. Army Corps of Engineers and New Jersey Department of Conservation and Economic Development, 1968, Passaic River basin water resources development: New York Army Engineer District, Inf. Bull., 62 p.

U.S. Bureau of the Census, 1961, U.S. census of population: 1960. Number of inhabitants, New Jersey: U.S. Bur. Census, Final Rept. PC (1) -32 B, $28 \mathrm{p}$.

1971, U.S. Census of population: 1970. Number of inhabitants, New Jersey: U.S. Bur. Census, Final Rept. PC (1)-A32, 45 p.

U.S. Geological Survey, 1960, Compilation of records of surface waters of the United States through September 1950, part 1-B, North Atlantic slope basins, New York to York River: U.S. Geol. Survey Water-Supply Paper $1302,679 \mathrm{p}$.

1964, Compilation of records of surface waters of the United States, October 1950 to September 1960, Part 1-B, North Atlantic slope basins, New York to York River: U.S. Geol. Survey Water-Supply Paper 1722, $578 \mathrm{p}$.

1970, Compilation of records of surface waters of the United States, October 1960 to September 1965, part 1-B, North Atlantic slope basins, New York to York River: U.S. Geol. Survey Water-Supply Paper 1902, $924 \mathrm{p}$.

U.S. Weather Bureau, 1963, Decennial census of United States climatemonthly averages for state climatic divisions, 1931-60, New Jersey: Climatography of the United States, no. 85-24, 2 p.

Wilson, J. F., Jr., 1968, Time-of-travel measurements and other applications of dye tracing: Internat. Assoc. Sci. Hydrol. Pub. 76, p. 252-262.

Wilson, J. F., Jr., and Forrest, W. E., 1965, Potomac River time-of-travel measurements: Symposium on Diffusion in Oceans and Fresh Waters, Lamont Geol. Observatory, New York, 1965, Proc., p. 1-18.

World Meteorological Organization, 1956, Technical regulations, General: World Meteorol. Organization, 1st ed., WRD-49, v. 1. 


\section{INDEX}

[Italic page numbers indicate major references]

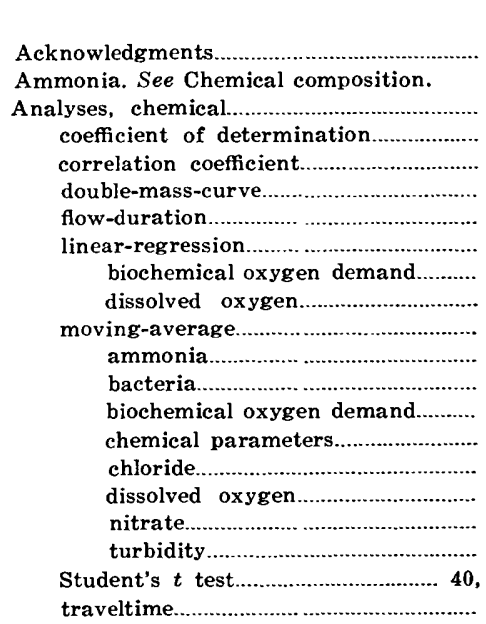

Page

4, 34 traveltime...

$46,64,75$

Bacteria

Basic data sources. 2

Biochemical oxygen demand........................ 46, 75 effect of dilution....................................... 48

Hanover Neck

linear-regression analyses

48,50

Little Falls

$46,48,59$

long-term changes

57,59

moving-average analyses

projected load..

46,57

relation to discharge.

relation to dissolved oxygen.

relation to temperature

53,54

seasonal variation

Student's $t$ test

Two Bridges.

variation with time

Biochemical quality

Chemical analyses

Chemical composition ammonia $38,61,74,75$

Little Falls.

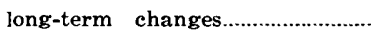
moving-average analyses............... relation to dissolved oxygen........... relation to nitrate.

variation with location. chloride $38,44,45,74$ detergent load units long-term changes
Chemical composition-Continued nitrate.....................................38, 61, 74, 75

Page

$\begin{array}{ll}\text { Little Falls ....................................... } & 61 \\ \text { long-term changes........................ }\end{array}$

moving-average analyses................. 62

relation to ammonia......................... 63

variation with location..................... 62

nitrogen compounds................................... 61

orthophosphate ........................................ 37

phenolic material........................................ 37

silver......................................................... 35

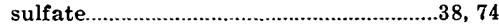

trace elements.......................................... 34, 36

relation to discharge................................ 38

variation with location........................... $\quad s 1$

Chemical quality......................................... 29,73

variation with time............................... 38

Coliform bacteria ................................. 46, 64, 75

Color of water

Detergent.................................................... 37

Discharge.............................................. 17, 73

relation to biochemical oxygen demand.................................... 49

relation to chemical composition......... 38

relation to dissolved oxygen .................. 48

relation to dissolved solids..................... $\quad 29$

relation to sediment load.......................66, 68

relation to traveltimes..................... 24, 26, 27

variation in magnitude......................... 18

variation with time................................ 15

See also Streamflow.

Dissolved oxygen................................... 45, 46, 75

Chatham ........................................... 55

Hanover Neck.................................................. 55

linear-regression analyses....................... 51

Little Falls......................................... 46, 61

long-term changes..................................... 59

Millington............................................ 55

moving-average analyses..................... 46, 55

Pine Brook .......................................... 57

Pompton River system............................... 57

projected load.............................................. 61

relation to ammonia oxidation............... 63

relation to biochemical oxygen demand......................................... 53, 54

relation to discharge................................. 48

relation to temperature........................... 51

reserve................................................. 54

Two Bridges........................................ 57

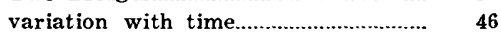

Dissolved solids..................................... 29, 73, 74

relation to discharge................................ 29

sampling sites........................................... 29
Rockaway-Whippany River system.... 57 


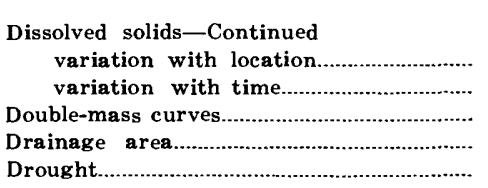

Effluent

$7,18,45,46$

Evapotranspiration

Flow-duration curves

Gaging stations

Chatham.

flow-duration curves.............................

Little Falls.

Pompton Plains

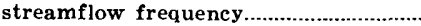

Two Bridges

See also Sampling sites.

Ground water, influent

Hardness

Location of basin

7,31

Management of water quality.

Management of water resources

Nitrate. See Chemical composition.

Phenolic material

Physical quality.

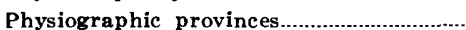

Pollution

assimilation capacity of river.

control.

indicators.............................................. 37 ,

industrial

45,46

organic.

54,64

projected loads.

transport of contaminants.

Pompton River system

Population

annual.

deficiency

drought.

extremes

monthly......

variations

Purpose of project

Rockaway-Whippany River system..

Saddle River system

Sampling sites
Sampling sites-Continued

Chatham, chloride...

dissolved oxygen.

dissolved solids

sediment load.............................. $66,68,71$

Hanover Neck.................. 44, 55, 57

Little Falls, ammonia............................ 61

biochemical oxygen demand.... 46, 48, 59

chemical parameters......................... 38

dissolved oxygen ............................. 46, 61

dissolved solids................................. 29

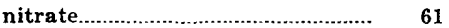

sediment load........................... 66, 68, 71

Mahwah.............................................. 67, 71

Millington......................................... 29, 44, 55

Pine Brook ....................................... 45, 57

Two Bridges, biochemical oxygen demand.................................... 58

chemical parameters........................ 38

chloride .............................................. 45

dissolved oxygen............................... 57

dissolved solids................................. 29

See also Gaging stations.

Sediment load.............................................. 66

annual.................................................. 66, 68

areal variation ..................................... 67

Chatham...................................... 66, 68, 71

controlling factors................................. 67

frequency............................................ 68,69

Little Falls..................................... 66, 68, 71

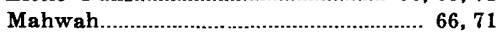

manmade effects .................................... 68,69

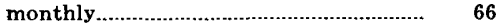

particle-size distribution........................ 71

relation to discharge............................ 66,68

turbidity............................................... 69

Streamflow...................................................... 15

diversions.................................................. 7

frequency ................................................... 17

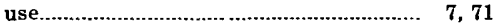

velocity...................................................... 18

See also Discharge.

Summary

Temperatures.

$50,51,65$

Traveltimes ............................................. 18, 23, 75

channel control...................................... 24, 26

dispersion of dye....................................... 28

peak dye concentration............................ 26

reaches measured..................................... 22

relation to discharge...................... 24, 26, 27

section control....................................... 24, 26

total for combined reaches................... $\quad 22$

variation with distance......................... $\quad 27$

Water use.................................................. 7, 71

effluent disposal.................................... 7

public supply ........................................ 7,27 